INTER NATIONAL MONETARY FUND
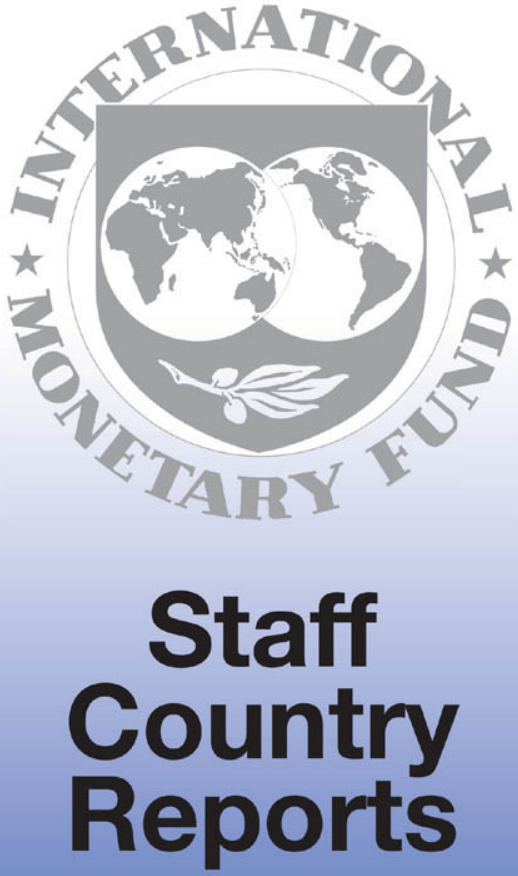


\section{Morocco: Financial System Stability Assessment}

including Reports on the Observance of Standards and Codes on the following topics: Banking Supervision, Insurance Regulation, Securities Regulation, Payment Systems, and Monetary and Financial Policy Transparency

This Financial System Stability Assessment on Morocco was prepared by a staff team of the International Monetary Fund and the World Bank as background documentation for the periodic consultation with the member country. It is based on the information available at the time it was completed on April 8, 2003. The vicws expressed in this document are those of the staff team and do not necessarily reflect the views of the government of Morocco or the Executive Board of the IMF.

A response by the authoritics of Morocco is attached.

The policy of publication of staff reports and other documents by the IMF allows for the deletion of market-sensitive information.

To assist the IMF in evaluating the publication policy, reader comments are invited and may be sent by e-mail to publicationpolicy@imf.org.

Copies of this report are available to the public from

International Monetary Fund - Publication Services

700 19th Street, N.W. - Washington, D.C. 20431

Telephone: (202) 6237430 - Telefax: (202) 6237201

E-mail: publications@imf.org • Internet: http://www.imf.org

Price: $\$ 15.00$ a copy

International Monetary Fund

Washington, D.C. 


\title{
MOROCCO
}

\section{Financial System Stability Assessment}

\section{Prepared by the Monetary and Exchange Affairs and Middle Eastern Departments}

\author{
Approved by Stefan Ingves and George T. Abed
}

April 8, 2003

This Financial Sector Stability Assessment (FSSA) is based on the work of a joint IMF-World Bank mission that visited Morocco as part of the Financial Sector Assessment Program (FSAP), during the periods January 29-February 13 and May 8-22, 2002. The mission met with senior management and staff of the Bark Al-Maghrib (BAM), the Ministry of Finance (MoF), and supervisory agencies, and with representatives of the financial sector. The findings of the FSAP mission were discussed with the authorities during January $23-30,2003$, in the context of the 2003 Article IV consultation.

The FSAP missions took place in the dynamic context of an ongoing reform program implemented by the authorities since the early 1990s. In the financial sector, this program aims at establishing a modem, market-oriented financial system that optimizes the mobilization of savings and the allocation of financial resources. So far, the reforms have focused mainly on overhauling the financial system's legal and regulatory framework. Thus, a comprehensive set of new laws and regulations was introduced in seven broad areas: (i) modemization of the banking sector and the development of competition within the sector; (ii) development of financial markets and, more generally, of alternatives to bank financing; (iii) removal of constraints on financial system activity' (iv) reduction of the government's involvement in the financial sector;

(v) reorientation of the financing of the government budget towards market-based instruments; (vi) introduction of a program aimed at developing institutional savings; and (vii) gradual liberalization of the exchange regime with a view to integrating the Morocan financial system into global financial markets. It was in the context of this ongoing reform program that the authorities requested an FSAP.

The mission found that, in the present context, the immediate risk of a financial crisis appears low, even though some individual institutions are troubled. Nonetheless, existing vulnerabilities will have to be addressed, as the trend towards increased openness is likely to challenge the stability of the system in the medium term. In particular, there is a need to resolve urgentily the situation of the state-owned specialized banks, address the fragility of several components of the nonbank finaricial system, and strengthen prudential supervision.

The authorities welcomed the FSAP's assessment, shared its main conclusions, and started implementing a mumber of FSAP recommendations after the end of the May-2002 mission. Although the assessment contained in this report is generally based on the situation as of May-2002, to the extent feasible, an effort has been made to take into account the measures taken by the authorities by the time of the Article IV consultation.

The missions were led by Messrs. Christian Durand (Mission Chief, IMF) and Wafik Grais (Deputy Mission Chief, World Bank) and comprised Messrs. Fenando Delgado, Wim Fonteyne, and Laurent Bouscharain, and Ms. Roxana Nikdjou (Assistant) (all IMF/MAE); Messrs. Giovatini Majnoni, Alain Laurin, Charlie Garrigues, Gregorio Impavido, Lue Cardinal, Loic Chiquier, Ferid Belhaj, and Andres Jaime, and Ms. Nicole Wauthiez (Assistant) (all World Bank), Ms. Annabelle Assemat (IFC), Mr. Badreddine Barkia (Bank of Tunisia), Messrs. Michel Svetchine and Dominique Bauer (both Bank of France), and Mr. Olivier Raynaud (French Banking Commission).

This report is divided in two parts. The first part presents the main findings and overall assessment, while the second part presents a summary assessment of observance of standards and codes regarding banking supervision, insurance regulation, securities markets, payment and settlement systents, and transparency in monetary and financial policies.

The main authors of this report are Messrs. Christian Durand, Fernando Delgado, Wim Fonteyne, and Laurent Bouscharain (all IMF/MAE). 


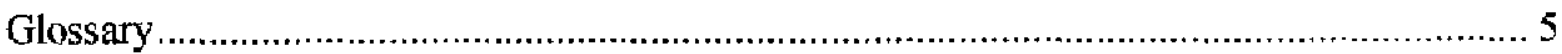

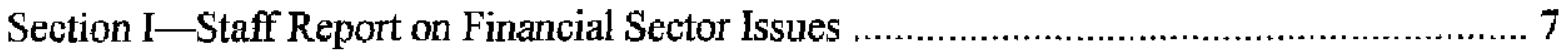

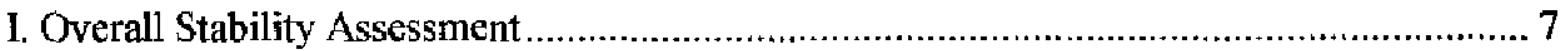

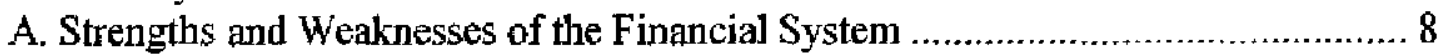

B. Opportunities and Risk Factors Facing the Financial System ........................... 10

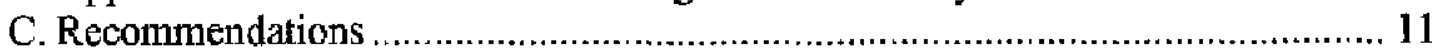

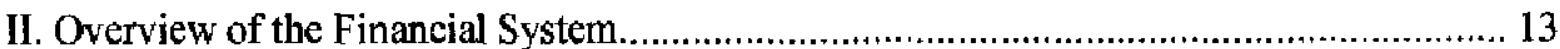

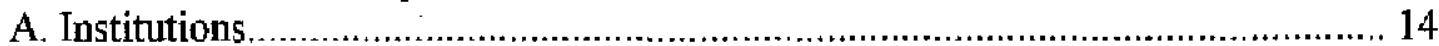

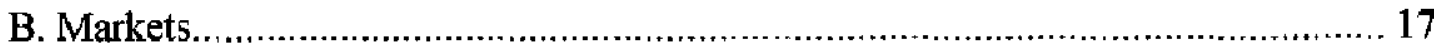

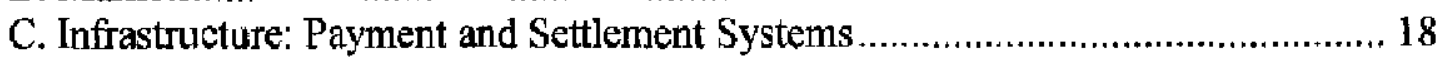

D. Regulation and Supervision....................................................................... 19

III. Financial System Stability: Macroeconomic and Macrofinancial Factors..................... 19

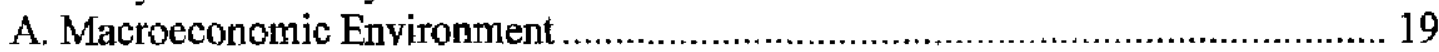

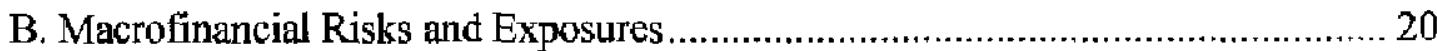

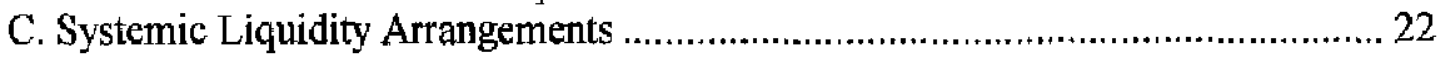

IV. Vulnerabilities and Soundness of the Financial System ....................................... 23

A. Potential Channels of Contagion: Interlinks Within the Financial Sector............ 23

B. The Banking System ........................................................................ 24

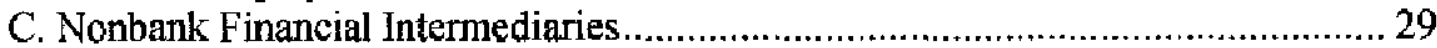

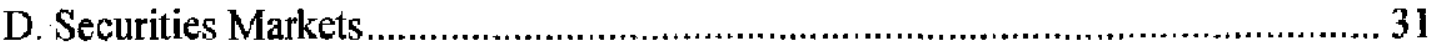

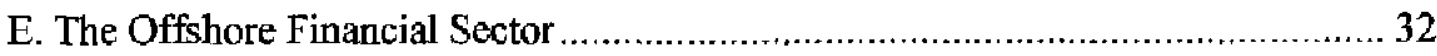

V. Regulation, Supervision, Crisis Management, and Safety Nets.................................32

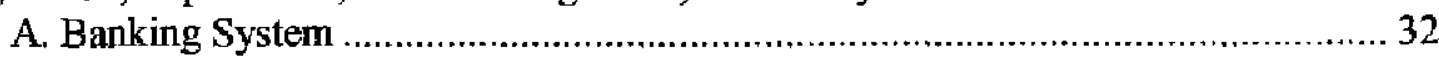

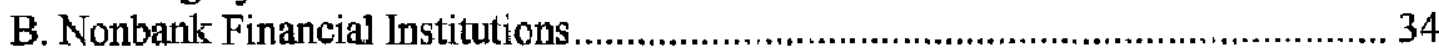

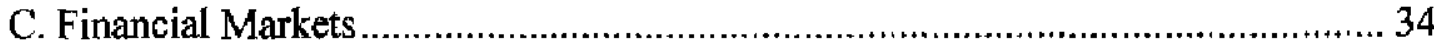

VI. Legal Framework, Infrastructure, and Governance ................................................. 35

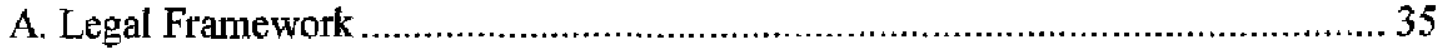

B. Anti-Money Laundering and Combating the Financing of Terrorism...................35

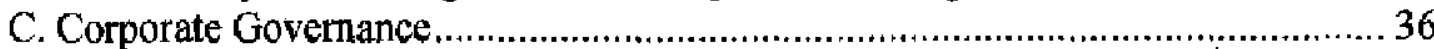

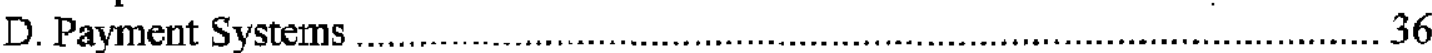

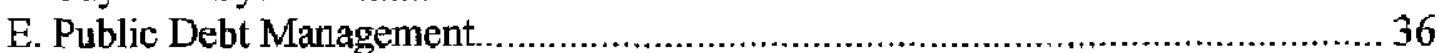

F. Transparency of Monetary and Financial Policies .......................................... 37

G. Accounting and auditing .................................................................... 37

VII. Challenges and Opportunities for Future Development of the System ........................ 38

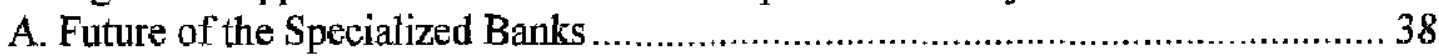

B. Fostering the Development of the Financial System........................................ 38 
Section II-Observance of Financial System Standards and Codes: Summary Assessments 40

I. Summary Assessment of Observance of the Basel Core Principles for Effective Banking

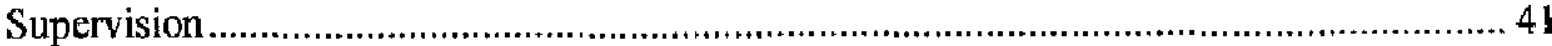

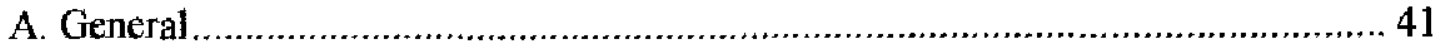

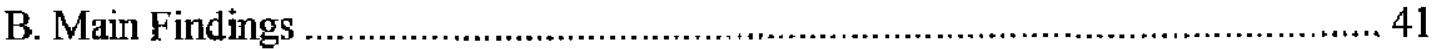

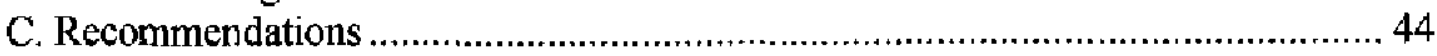

II. Summary Assessment of Observance of the LAIS Insurance Core Principles...................46

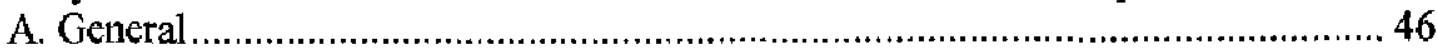

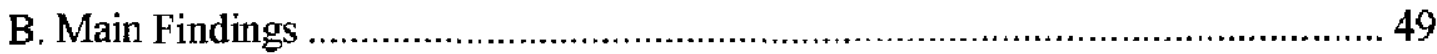

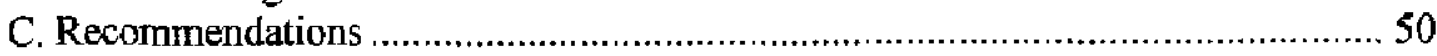

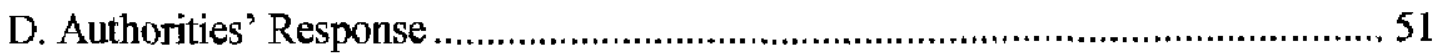

III. Summary Assessment of Observance of the IOSCO Objectives and Principles for

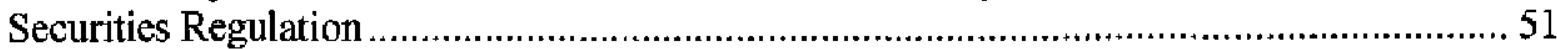

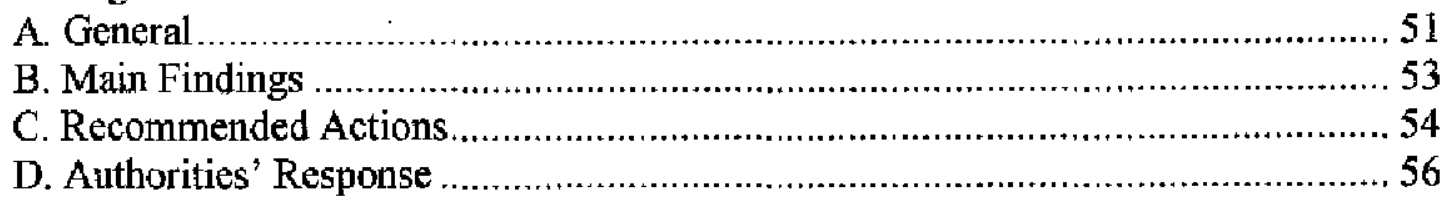

IV. Summary Assessment of Observance of the CPSS Core Principles for Systemically Important Payment Systems ................................................................................... 57
A. General
B. Main findings .

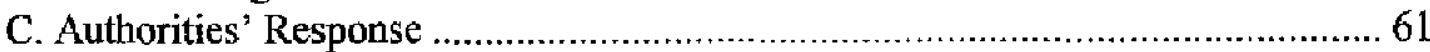

V. Summary Assessment of Observance of the Code of Good Practices on Transparency in Monetary and Financial Policies.
A. Code of Good Practices on Transparency in Monetary and Financial Policy-
Monetary Policy.
B. Code of Good Practices on Transparency in Monetary and Financial Policy- Financial Policies

Tables

1. Main Recommendations of the BCP Assessment

2. Recommended Action Plan for Improving Observance of the IAIS Insurance Core

Principles

3. Recommended Action Plan for Improving Observance of the IOSCO Objectives and

Principles for Securities Regulation.

4. Main Findings of the Assessment of Observance of the Core Principles for Systemically Important Payment Systems

5. Action Plan for Improving Observance of the Core Principles for Systemically Important

Payment Systems .............................................................................5 59

6. Main Findings of the Assessment of Observance of the Code of Good Practices on

Transparency-Monetary Policy 
7. Recommended Actions to Improve the Transparency of Monetary Policy 63

8. Summary of Main Findings of Assessment of Observance of Transparency Code ......... 65

9. Recommended plan of Action for Improving Transparency of Financial Policies ..........., 66

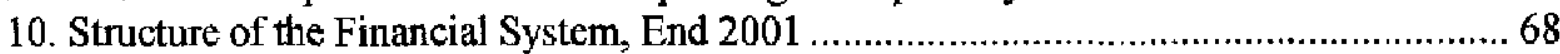

11. Overview of Regulatory and Supervisory Responsibilities, $2001 \ldots \ldots \ldots \ldots \ldots \ldots \ldots \ldots \ldots \ldots .69$

12. Shareholdership of Selected Components of the Moroccan Financial System ............... 70

13. Credit Exposures Between Components of the Moroccan Financial System ................. 70

14. Indicators of Financial Soundness of the Banking System, 1997-2002 …................ 71

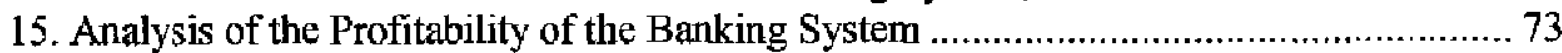

16. Aggregate Balance Sheet for the Banking System at End December 2001 …............... 74

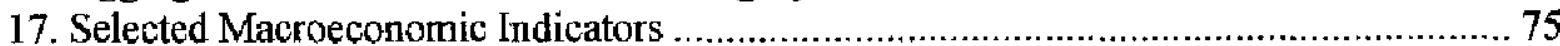

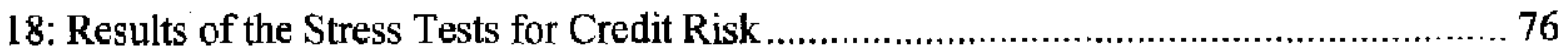




\section{GLossary}

\begin{tabular}{|c|c|}
\hline AMC & Approved Microcredit Association \\
\hline AML & Anti-Money Laundering \\
\hline BAM & Bank Al-Maghrib (the Moroccan central bank) \\
\hline $\mathrm{BCP}$ & Banque Centrale Populaire (the central entity of the CPM) \\
\hline $\mathrm{BCP}$ & Basel Core Principles \\
\hline BNDE & Banque Nationale du Développement Economique \\
\hline CAR & Capital Adequacy Ratio \\
\hline $\mathrm{CCG}$ & Caisse Centrale de Garantie \\
\hline $\mathrm{CCP}$ & Comptes des Chèques Postaux \\
\hline CDEC & Commission de Discipline des Établissements de Crédit \\
\hline CDG & Caisse de Dépôt et de Gestion \\
\hline CDVM & $\begin{array}{l}\text { Conseil Déontologique des Valeurs Mobilières } \\
\text { (Securities Ethics Council) }\end{array}$ \\
\hline $\mathrm{CEC}$ & $\begin{array}{l}\text { Comité des Établissernents de Crédit } \\
\text { (Credit Institutions Committee) }\end{array}$ \\
\hline CEN & Caisse d'Épargne Nationale (National Savings Bank) \\
\hline CFT & Combating the Financing of Terrorism \\
\hline $\mathrm{CH}$ & Crédit Immobilier et Hôtelier \\
\hline CNCA & Caisse Nationale de Crédit Agricole \\
\hline CNME & Conseil National de la Monnaie et de l'Épargne \\
\hline CNSS & Caisse Nationale de Sécurité Sociale \\
\hline CPM & Crédit Populaire du Maroc \\
\hline CPSIPS & Core Principles for Systemically Important Payment Systems \\
\hline CPSS & Committee on Payment and Settlement Systerns \\
\hline DAPS & $\begin{array}{l}\text { Direction des Assurances et de la Prévoyance Sociale } \\
\text { (Insurance and Social Security Directorate at the MoF) }\end{array}$ \\
\hline DCEC & $\begin{array}{l}\text { Direction de Contrôle des Établissements de Crédit } \\
\text { (Credit Institutions Supervision Directorate at the } \\
\text { BAM) }\end{array}$ \\
\hline EU & European Union \\
\hline $\mathrm{FCB}$ & Finance Company Bill \\
\hline FCP & $\begin{array}{l}\text { Fonds Commun de Placement } \\
\text { (type of closed-ended mutual fund) }\end{array}$ \\
\hline FEC & Fonds d'Equipement Communal \\
\hline FIU & Financial Intelligence Unit \\
\hline FMSAR & $\begin{array}{l}\text { Fédération Marocaine des Sociétés d'Assurance et de } \\
\text { Réassurance (association of insurers and reinsusers) }\end{array}$ \\
\hline FSAP & Financial Sector Assessment Program \\
\hline FSSA & Financial Sector Stability Assessment \\
\hline GPBM & $\begin{array}{l}\text { Groupement Professionel des Banques Marocaines } \\
\text { (Moroccan Bankers' Association) }\end{array}$ \\
\hline IAIS & International Association of Insurance Supervisors \\
\hline IAS & International Accounting Standards \\
\hline IVT & $\begin{array}{l}\text { Intermédiaire en Valeurs de Trésor (market maker in treasury } \\
\text { bills) }\end{array}$ \\
\hline Mol & Ministry of Finance \\
\hline
\end{tabular}


NPL

OFS

OPCVM

PONA

SBVC

SCR

SICAY

SIMT

SME

SRO

TCN
Nonperforming Loan

Organisme Financier Spécialisé (Specialized Financial Institution - former designation of the state-owned specialized banks)

Organisme de Placement Collectif de Valeurs Mobiliers (mutual fund)

Position Nette Acheteuse (buyer's position)

Société de la Bourse des Valeurs de Casablanca

(Casablanca stock exchange company)

Société Centrale de Réassurance (central reinsurance company)

Société d'Investissement à Capital Variable

(type of open-ended mutual fund)

Système Interbancaire Marocain de Télécompensation

(interbank teleclearing system)

Small or Medium Enterprise

Self Regulatory Organization

Titre de Créance Négotiable (negotiable debt instrument) 


\section{SECTION I-STAFf REPORT ON FinanCial SECTOR IsSUES}

\section{OVERaLl Stability ASSESSMENT}

1. During the past decade, Morocco has successfully undertaken a series of regulatory and institutional reforms aimed at putting in place the key components of a modern financial system. Markets, however, remain shallow, while the government still plays an important role and restrictions on capital movements apply to residents. In this context and in the short term, the immediate risk of a financial crisis appears low, and the financial system is unlikely to be a source of macroeconomic risk, even though two state-owned specialized banks are troubled. In the medium term, however, the trend towards increased economic and financial integration of Morocco in the global economy is likely to challenge the stability of the system and hence, there is a need to address existing institutional vulnerabilities-in particular, the weaknesses in financial supervision, the fragility of the nonbank financial sector, and the underdevelopment of the financial system infrastructure.

2. Morocco's financial sector environment has been evolving since the authorities started an ambitious reform process in the beginning of the 1990s. This process has been aimed at establishing a modern, market-oriented financial system that optimizes the mobilization of savings and the allocation of financial resources. Over the past decade, the reforns have focused mainly on overhauling the financial system's legal and regulatory framework, with a view to putting in place all the components of a modern financial system, removing constraints on financial system activity, and increasing the role of market forces.

3. For the most part, these reforms have been successful, and from an institutional perspective, Morocco now has one of the most modern and developed financial systems in North Africa. In spite of this success, however, markets continue to play only a limited role, government ownership of financial institutions remains widespread, the improvernent of financial practices has lagged behind institutional developments, and competition outside the banking system tends to be limited as a result of the dominant position of three large private financial conglomerates. Hence, the reform program remains to be completed, among other things by introducing more transparency in the operations of state-owned institutions and supervisory authorities.

4. The immediate risk of a systemic crisis appears limited, since the banking system is insulated from the most plausible external shocks, current macroeconomic conditions are relatively strong, consistent policies and practices limit the transmission of shocks, and the large commercial banks appear well capitalized and sound (see Table 14). A framework consisting of various controls and regulations, continuous government involvement, restrictions on capital movements by residents, and a monetary policy that has not fostered the emergence of an active interbank market make the system virtually immune to developments in intemational financial markets, with the exception of potential variations in remittances from Moroccans living abroad. Furthermore, problems have up to now been dealt with mainly through government intervention, including through the financial institutions it controls, and contagion effects have been limited due to the absence of active 
domestic financial markets. While this has prevented problems from spreading, it has led to a lack of transparency and delayed the development of a strong, efficient, and competitive financial system.

5. The main short-term challenge facing the authorities is the need to address the situation of two troubled state-owned specialized banks which still operate in exemption of key prudential regulations. Close monitoring of their activity and soundness is also required to avoid contagion effects through distortion of competition or weakening of the institutions that have brought support.

6. In the medium to long run, the inevitable trend toward increased openness is likely to challenge the stability of the macroeconomic framework and to render the financial system's current protective and controlled environment unsustainable. Morocco will only be able to realize its full economic potential and meet the challenge of a rapidly growing labor force through integration in the global economy. The Moroccan authorities are aware of this and have taken important steps in that direction, including membership in the WTO and an Association Agreement with the EU. At present, however, the Moroccan financial system and its macroeconomic and financial policy frameworks are insufficiently prepared for the challenges increased openness will bring.

7. To avoid unnecessary instability during the transition toward more open economic and financial systems, Morocco will need to address existing vulnerabilities, accelerate and complete the reform process on which it has embarked, and further strengthen the financial system's regulatory and supervisory framework. The financial system will need to be adapted to a more exposed, more volatile and substantially more competitive environment. This will require a completion of the government's withdrawal from the financial sector, the resolution of troubled institutions, and the consolidation and strengthening of weak subsectors of the financial system. In addition, regulation and supervision will need to be strengthened and refocused on the analysis and management of risks. Finally, key elements of the financial system infrastructure--such as the legal and judicial framework, the payment system, the accounting and auditing systems, and the educational and public information systems-will need to be adapted and made more robust so as to strengthen their support to financial activities.

\section{A. Strengths and Weaknesses of the Financial System}

8. The main strength of the financial system lies in the apparent robust health of the large commercial banks. The data provided to the mission by Morocco's central bank, the BAM, suggest that the large commercial banks are relatively well placed to cope with a range of plausible short-term shocks. The most important risk to which they are exposed, credit risk, appears contained, since stress tests indicate that they would be able to withstand a significant deterioration of their loan portfolios owing to sectoral or economy-wide shocks.

9. The main immediate banking system weakness is the precarious solvency and liquidity situation of two large state-owned specialized banks. At this stage, the systemic risk appears contained, thanks to the support that the government and some state-owned 
financial institutions have provided within the framework of six-year restructuring plans. However, this practice has weakened the supporting institutions, introducing a risk of contagion within the state-owned segment of the financial system, and it risks gaining time at the expense of an increased ultimate cost to the budget. In addition, the decision to exempt these distressed institutions from prudential regulations and reserve requirements while they are being restructuring is an undermining factor for the credibility of the banking supervisor and distorts competition among banks. To deal with the problem, the EU is currently assisting the Moroccan authorities in designing a future strategy for these banks.

\section{The main medium-term vulnerabilities of the financial system can be found at} the level of certain nonbank financial institutions and sectors. The country's pay-as-yougo pension system is unbalanced; the securities industry is operating at a loss and has no realistic prospect of a return to a profitable level of activity; most insurance companies are financially weak and have problems observing prudential regulations; and the state-owned reinsurance company is not viable without government support.

11. The overall weakness of financial sector supervision-which is reflected in a low degree of observance of international standards and codes on banking supervision, insurance oversight and securities regulation-implies that problems may not be detected early enough to allow adequate and timely corrective action. The main weaknesses of prudential supervision lie in its incomplete coverage (some institutions are exempt), insufficient independence, inadequate resources, and lack of coordination between the different supervisory agencies in a context of a substantially interconnected financial sector. The latest version of the draft banking law available to the staff acknowledges these weaknesses and significantly increases the powers of the BAM's governor while proposing the creation of a coordinating body where all financial supervisors will be represented.

\section{Some financial sector weaknesses may be underestimated as a result of problems} with financial and accounting statements. Such data problems could be caused by the identified shortcomings in the accounting and auditing systems, insufficient enforcement of existing auditing and accounting requirements, and by an inadequate degree of consolidation in the assessment of credit risk exposure to interrelated borrowers. However, in the case of the commercial banking system, this potential underestimation is unlikely to be of a scale that would threaten compliance with key prudential ratios. Similarly, although there are weaknesses in the loan classification and provisioning rules, these, by themselves, do not appear to be of a scale and scope as to fundamentally alter the reported financial health of the banks when addressed.

\section{Constraints on the role of market forces have contributed to a low degree of} transparency and an absence of reliable benchmarks and price signals. The authorities' control over several financial institutions and their hesitation to allow market forces to play out fully have led them to opt for a discretion-based system for their involvement with the financial sector, rather than for a rules-based system that would enhance transparency but limit their freedom of action. In addition, the closed character of the market has removed all external references while shallow secondary markets have prevented the establishment of a reliable benchmark interest rate and yield curve. Transparency is further hampered by a 
number of institutional and legal features, including the absence of central bank independence and the existence of equity and managerial links between the BAM and the financial institutions it supervises.

\section{B. Opportunities and Risk Factors Facing the Financial System}

\section{The financial system could contribute much more to economic growth and}

development. A series of structural issues, including the extensive role of the government, limited competition, and the presence of impediments to financial sector activity have led to an uneven development of the system and held back its contribution to economic development and poverty reduction. The majority of the population has no access to credit and other financial services from the financial system. This has contributed in turn to weak institutional savings that have, among other factors, retarded the development of capital markets.

\section{Increased openness would bring important benefits and new opportunities to} Morocco's financial institutions and other economic agents alike. Financial institutions would be able to pursue new opportunities abroad, improve the risk-reward trade-off of their asset portfolios through increased diversification, and obtain increased access to capital, technology and know-how. Moroccan consumers and businesses would benefit from a broader, more competitive, and more innovative range of financial products and services.

\section{Other factors that could negatively affect Moroccan banks include fiscal} problems, a reduced willingness of the public to hold unremunerated demand deposits, a reversal in remittances, and a compression of interest margins. The re-emergence of government arrears could significantly affect the banks' loan portfolios, through its effects on the liquidity and solvency of banks' customers. Similarly, hypothetical disruptions in government debt service persisting for any significant period of time would be detrimental to the banks, through the effect on their substantial holdings of government debt. The authorities' choice to finance the budget deficit mainly from domestic sources has increased this vulnerability by driving up the share of goverument debt in the financial system's assets. Commercial banks are also exposed to transformation risk. Up to now, these banks have benefited from an increasing abundance of unremunerated demand deposits (which constitute 41 percent of the balance sheet of commercial banks). However, any development that would significantly reduce depositors' willingness to hold such deposits would affect the banks' liquidity and profitability and could, if occurring suddenly, trigger a liquidity crisis. Remittances have been a major factor in the steady growth of deposits. However, although these remittances have shown a remarkable stability thus far, it cannot be excluded that shocks to confidence could result in a drying up or reversal of these inflows, which in turn could cause major disruptions in the Moroccan financial sector. Finally, stress tests indicate that the commercial banks' profitability is vulnerable to a further reduction in interest margins, which could be brought about by increased competition.

17. The inefficiency of the legal and judicial systems remains an impediment to the development of the financial sector. It could become a source of risk as well, if increased competition prompts the banks to seek out less viable customers. The authorities' efforts to 
improve the legal and judicial framework, in particular through the creation of commercial courts, are likely to improve the implementation of existing legislation on bankruptcy and creditors' rights. In addition, Morocco's legislation does not conform to international standards on combating money laundering and the financing of terrorism.

\section{Recommendations}

18. To maximize the benefits and minimize the risks of a desirable further opening toward the rest of the world, careful preparation and management, as well as adequate sequencing, are required. As far as the financial system is concerned, these efforts will need to aim at improving the macroeconomic framework, strengthening the financial system, and creating an appropriate infrastructure to foster the system's development.

19. Sound macroeconomic policies are essential for the stability of a financial system in an open economy. The main macroeconomic challenges that have to be addressed are Morocco's remaining fiscal problems, the insufficient diversification of the economy, and the need to establish an independent monetary policy with a mandate for price stability. Furthermore, policies need to be put in place to improve the competitiveness of Moroccan enterprises and help them benefit from the Association Agreement with the European Union.

20. It is of fundamental importance that economic reform be phased properly, if the benefits of liberalization are to be realized while safeguarding the stability of the financial system. In particular, substantial further steps towards opening the capital account can only proceed once the financial system is sound, banking supervision is strong and an effective monetary policy has been established that enables the central bank to independently manage short-term interest rates.

21. The financial system institutions need to be restructured and financial policies strengthened. As a minimum, this would require the following steps:

- Resolution of the two most troubled state-owned banks. Given that these banks are insolvent and operate in exemption of key prudential ratios, remedial action is urgently needed.

- A review of procedures to handle problem banks, in order to increase transparency and reduce moral hazard by abandoning the present policy of avoiding bank closures at all costs. State support for public entities in difficulty should henceforth be given in a transparent manner and using budgetary resources, rather than by calling on the resources of other public institutions.

- Efforts to address the fragility of non-bank financial institutions, including in particular the pension funds. These efforts should encompass the identification of all troubled institutions, audits of their finances, the design of effective and transparent restructuring strategies, the introduction of a clear delineation between public services and commercial activities, and safeguards to avoid the distortion of competition. 
- A clarification of the role of the public financial institutions. At present, these institutions fulfill public mandates and pursue commercial activities at the same time, which distorts competition and does not allow to monitor management efficiency. A clearer definition is needed of their role in attracting and managing funds, lending, and other financial services. This is particularly crucial in the case of significant financial institutions such as $\mathrm{CDG}, \mathrm{BCP}$, the postal system and CNCA. The continued government ownership of those institutions with a commercial role will have to be reconsidered.

- A withdrawal of the central bank from the capital and boards of all other financial institutions. The central bank law should be revised accordingly to prohibit such participations in the future.

A reinforcement of financial supervision. To help detect vulnerabilities at an early stage, ensure healthy competition, protect consumers and shore up public trust in the financial system, there is a need for independent oversight bodies equipped with adequate resources and authority. This independence should be accompanied by mechanisms of increased accountability and reporting. The supervisory bodies themselves will need to increase their effectiveness by developing a more risk-based approach to supervision, and by establishing greater coordination or integration among them. Also, the authorities will need to ensure that the fact that the BAM is not responsible for licensing decisions does not undermine its authority, and that it has a decisive input in licensing decisions. If that is not possible, consideration will need to be given to moving the licensing authority to the BAM. Finally, there is a need to compile and monitor data on the duration mismatch, the open foreign currency position and maturity mismatch in the banks' foreign currency books.

\section{The development and stability of the financial system can be fostered through} the creation of an environment and infrastructure that is supportive of financial activities. To that effect, the authorities need to extend efforts already underway in the legal and judicial areas, and the central bank needs to work with other interested parties to develop modern means of payment and a large-value settlement system, as well as thoroughly up-todate accounting and auditing systems. Furthermore, the creation of a database with information on bad debtors would greatly facilitate the provision of credit. Finally, the financial sector would benefit from the removal or relaxation of several distortions created by taxes and price restrictions, such as the tax on foreign exchange transactions, the "usury" rate, and the ceiling on automobile insurance premiums.

23. These actions should fit within a consistent and comprehensive strategy. This strategy should be broadly based, coordinated with other interested parties, and supported by a communications strategy. In that regard, the way the troubled state-owned financial

${ }^{1}$ These public mandates consist, among other things, of financing priority sectors and public projects and providing financial services in rural areas. 
institutions are handled will send an important signal to the market, as will any decision on the level of independence of financial oversight bodies.

24. The ongoing banking law reform presents an opportunity to give the governor of the BAM more direct powers for crisis management, to entrust the BAM with the responsibility to oversee the Deposit Guarantee Fund, to end the BAM's participation in the capital and boards of directors of public financial institutions, and to abolish the market solidarity mechanism.

\section{OVERView OF The Financial SyStem}

25. Thanks in part to a decade of reform efforts, Morocco now has a relatively deep financial system. Financial sector assets amount to about 1.5 times GDP (see Table 10) and those of the banking system alone are equivalent to almost 90 percent of GDP. Monetization is moderately high, with broad money amounting to 88 percent of GDP, and, at 55 percent of GDP, bank credit to the private sector is at a level that compares favorably with those observed in other countries in the region.

26. However, the financial system has developed unevenly, and its geographical and population coverage remain limited. Retail banking coverage is low, with the number of bank accounts held by residents amounting to only 15 percent of the population, compared to 40 percent in Tunisia and over 100 percent in developed countries. The non-bank components of the financial system have limited influence over the economy. Contributors to pension funds represent only a small proportion of the labor force (24 percent) and apart from life insurance that is developing, other forms of optional insurance are quasi inexistant. The resulting weakness in institutional savings hampers the development of capital markets. The low coverage also contributes to the continuing relative importance of liquid aggregates, as large parts of the economy remain dependent on cash transactions. Currency in circulation constitutes 20 percent of broad money, and demand deposits another 53 percent.

\section{An institutional framework has been developed, but financial practices lag} behind. As a result of the reform efforts undertaken since the early-1990s, Morocco now has all the key components of a modern financial system (see Table 10), including an insurance sector, a stock exchange, securities firms, leasing companies and consumer finance companies. At the same time, however, it retains many characteristics of emerging and centralized systems, financial markets remain unevenly developed, and the payment system remains dominated by cash transactions and by the physical circulation of paper instruments.

28. The State continues to fulfill an important role. Although it intends to disengage itself from the financial sector, government-controlled institutions still held around 43 percent of all banking system assets at end-December $2001{ }^{2}$ In addition, some of the

${ }^{2}$ Including Crédit populaire du Maroc, which consists of a state-owned central institution (BCP) and 16 regional privately-owned banks. The entire group is considered public here because of the central institution's impact on its policies. 
most important non-bank financial institutions are State-owned. However, the ongoing reforms have increased the role of the private sector, while maintaining a substantial State presence.

29. Morocco's financial system is characterized by a limited degree of integration with the global financial system, except through ownership links. The system's focus is on financing the Kingdom's economy, and foreign activities are generally limited to those that support the domestic business, such as serving the needs of Moroccans living abroad. This domestic focus can be explained to a large extent by the presence of restrictions on capital account transactions, which restrict possibilities to expand or diversify abroad and limit competition from abroad in the domestic market. Nevertheless, many Moroccan financial institutions have foreign shareholders and such ownership links have greatly benefited the domestic system by facilitating the transfer of technology and know-how. The authorities are committed to further opening the financial sector to foreign investors.

30. The private financial sector is dominated by three conglomerates, one of which also has extensive industrial interests. This high degree of concentration has limited the competition and transparency necessary for the financial system to contribute fully to economic growth, development and poverty-reduction.

\section{A. Institutions}

\section{The banking system}

\section{The banking system dominates the financial system and consists of two}

subsectors. In May 2002, the Moroccan banking sector consisted of 19 banks divided into two subsectors, the first of which comprises 14 multipurpose banks (the "commercial banks") and the second five "specialized banks." The sector accounts for the bulk of financial system assets ( 60 percent, see Table 10 ), and plays a central role not only because of its size, but also because of its links with the other components of the financial system. Four commercial banks and four of the specialized banks (the "public banks") are majority state-owned, while foreign shareholders hold majority stakes in five institutions (the "foreign banks"). The six others are private, domestically-owned banks. The banking population remained stable from 1997 to 2001, but since the second half of 2001, the long-term trend towards concentration has resumed. Two mergers took place in the final quarter of 2001 and two others are underway. ${ }^{4}$

\section{Aggregate banking sector assets amounted to $\mathrm{DH} 345$ billion, or 90 percent of} GDP, at end-2001. The five specialized banks accounted for 18 percent of this amount, the

\footnotetext{
${ }^{3}$ Since then, two public specialized banks (BNDE and CNCA) have been merged.

${ }^{4}$ The two mergers that are currently underway will result in the disappearance of one public commercial bank and one private commercial bank.
} 
public banks 43 percent, and the foreign banks 20 percent. Seven commercial banks, of which one is public and three are foreign, dominate the commercial banking subsector. Together, they hold 94 percent of commercial banking assets and 76 percent of total banking system assets. The three largest of them represent, by themselves, about one half of the total banking system on a number of measures.

\section{The State continues to play an important role as a controlling shareholder of} banks. The government controls, directly or indirectly, the largest commercial bank in terms of assets, three small commercial banks, and four specialized banks (the former OFS's ${ }^{5}$ ). Overall, the public banking system represents 43 percent of total banking system assets. In addition, the State owns Caisse des Dépôts et de Gestion (CDG), an institution that has a dominant position in the management of institutional savings.

\section{While the differences between foreign and domestic banks, or even between} public and private banks, are not all that consistent, there is a marked dichotomy between the commercial and specialized banks. The basic activities of the commercial banks consist of collecting deposits and using these to provide loans-especially short-term loans to the private seetor-and to invest in treasury bills. With the exception of the Crédit Populaire du Maroc (CPM), they target an exclusive clientele of middle and upper class customers. The specialized banks, by contrast, were established to provide long-term financing to certain priority sectors, in particular agriculture (CNCA), housing and tourism $(\mathrm{CIH})$, local govemment (FEC), industry (BNDE), and the projects of Moroccans living abroad (Banque Al-Amal). As a result of this historically different focus, their balance sheets differ significantly from those of the commercial banks. On the liability side, the resources of the commercial banks consist essentially of customer deposits ( 83 percent of the total), whereas the specialized banks obtain their funds by issuing bonds underwritten by commercial banks or by the $\mathrm{CDG}^{6}$ ( 32 percent of their total resources) and by borrowing at long terms from international financial institutions ( 18 percent), while only 36 percent comes from deposits. As a result, the specialized banks' cost of funds is significantly higher than that of the commercial banks ( 6.7 percent versus 2.5 percent in 2001 ), resulting in a much smaller interest spread ( 1.3 percent versus 4.2 percent). On the asset side, the specialized banks devote 76 percent of their balance sheet totals to lending activities, as against 44 percent for the commercial banks. Furthermore, while the credits of the former are mostly long-term (58 percent), 61 percent of those of the commercial banks are short term. Finally, the commercial banks invest a large proportion of their assets ( 24 percent) in fixed-income securities (essentially treasury bills), while such investments represent no more than 6 percent of the specialized banks' assets. The combination of relatively high lending and low deposit collection results in a loan-to-deposit ratio that is much higher at the specialized banks ( 212 percent) than at the commercial banks ( 53 percent).

\footnotetext{
${ }^{5}$ The former OFS's are the BNDE, $\mathrm{FEC}, \mathrm{CIH}$, and CNCA.
}

${ }^{6}$ Banks are required to invest 2 percent of their deposits in securities issued by the $\mathrm{CNCA}$, which are remunerated at an interest rate of 4.5 percent. 
35. Customer deposits consist mostly of unremunerated demand deposits and low yielding liquid deposits. Non-interest bearing demand deposits represent almost half the total. Foreign currency deposits are marginal, at around 1 percent of total deposits.

\section{Non-bank financial institutions}

36. The CDG is a public, nonbank financial institution established to centralize and manage institutional savings. The CDG is financially autonomous and manages the assets of institutions such as the National Social Security Fund (CNSS) and the National Savings Bank (CEN). It also provides financial and administrative management of pension and insurance funds, is involved in economic development through equity investments, and conducts a variety of other public services and competitive commercial activities. With a balance sheet total of DH 34 billion (6 percent of the total financial system, see Table 10), it is a leading player in the financial sector. Its management is appointed by the government and consists mainly of (former) government officials. The CDG is not subject to any prudential supervision, but its accounts are audited by external auditors and by the National Audit Office.

\section{The insurance sector holds 11 percent of financial system assets and comprises} 18 companies, one of which is a government-controlled reinsurance company. Of the 17 regular insurance companies, 14 are private and three are mutually organized. The three largest companies - two of which belong to domestic financial conglomerates-dominate the system, although concentration indicators do not suggest excessive concentration. The assets of the sector totaled approximately DH 61 billion (17 percent of GDP) at the end of 2000 , and its premiums amounted to three percent of GDP. The Central Reinsurance Corporation (SCR) receives a mandatory ten percent of all the premiums issued by Moroccan insurance companies and benefits from an unlimited State guarantee. The insurance sector is regulated and supervised by the Ministry of Finance (DAPS).

\section{The Post Office ("Barid Al-Maghrib") offers a range of financial services} through its extensive branch network, but is not subject to the banking law. Alongside its traditional postal activities, it offers postal checking accounts (CCP), passbook savings accounts (organized as the $\mathrm{CEN}$ ) and a number of other financial services. The management of the collected deposits is entrusted to the treasury (for CCP funds) and to the CDG (for CEN funds). The Post Office has a wide network of 1,563 service counters (serving smaller customers whom the banks seek to avoid) but, with 18 percent of passbook savings and 5 percent of checking accounts, it handles only a small proportion of the Kingdom's savings.

39. The Moroccan pension system is composed of a large number of plans, but covers only a small part of the labor force. There is a wide range of pension schemes that differ from each other on a whole set of parameters (benefit formulas, contribution bases, vesting periods, contribution proportions, etc.). The schemes are managed by four public institutions and one association between public and private sector employers. Only the four public institutions are regulated and supervised, as no supervisory arrangements have been made for the public-private association. In spite of the variety in available pension plans, it is estimated that only 24 percent of the labor force participates in the system. 
40. The mutual funds industry is relatively undeveloped and is characterized by its close ties to the banking sector. The mutual funds (OPCVMs) tend to serve wealthy customers and institutional investors. As a result of a shortage of profitable investment opportunities, partially due to the high concentration among listed groups, 85 percent of the assets managed by the mutual funds are invested in treasury securities, and they hold only 5 percent of the stock market's capitalization. The sector is regulated and supervised by the CDVM.

\section{Although the leasing sector in Morocco is one of the most developed in the} region, it continues to be small within the financial system. Its main activity is the leasing of movable goods to companies. Close ties to the banking sector (eight out of nine companies are subsidiaries of banks) provide a reliable source of finance, and as a result more than half the leasing companies' overall financing comes from bank loans. The sector is regulated by the MoF and supervised by the BAM.

42. The microcredit sector is relatively new, and comprises 12 approved microcredit associations (AMCs), some of which have experienced very rapid growth. The 4 largest AMCs account for 92 percent of the beneficiaries and 95 percent of the total activity of the sector. The law on microcredit authorizes lending operations and the provision of related services, but not the collection of savings or deposits. As a result, the AMCs need to finance themselves through grants, public subsidies, borrowing, interest and commissions charged on their lending operations, and charitable contributions from the public. The regulatory and supervisory framework for AMCs remains to be defined.

\section{The offshore financial system}

\section{There are currently six offshore banks in Tangiers - all of which are associated} with credit institutions active in Morocco- but their level of activity remains modest. The law permits the creation of offshore banks with a liberal legal status and without subjecting them to banking supervision. They are authorized to attract deposits and make loans in foreign exchange to nonresidents, free of exchange controls for non residents and while benefiting from tax advantages. The offshore banks are subject to certain regulatory provisions, which are to be monitored by the external auditors. However, those regulatory provisions have not yet been made specific through the issuance of regulations.

\section{B. Markets}

\section{The institutional framework for the Casablanca stock exchange has been} strengthened by a series of reforms during the mid-1990s, but the market suffers from a lack of liquidity and confidence. The securities market is managed and organized by the Casablanca Securities Exchange Corporation (SBVC), a limited liability company owned by the local securities brokerage firms, which hold a monopoly on transactions. In addition to a limited number of public and private bonds, 53 companies are currently quoted on the stock exchange, with a total market capitalization equivalent to 28 percent of GDP. However, most traded securities suffer from a lack of liquidity, and since a reform-driven bull market petered out in 1998, the market and market confidence have languished. The securities market is 
regulated and supervised by the $\mathrm{MoF}$, which has authority over the SBVC and Maroclear, and by the CDVM, which oversees the brokerages.

45. The primary market for treasury bills functions well, but the secondary market remains limited to repo-operations. As part of the transition to a market economy, the financing of the treasury has changed significantly during the 1990s. Treasury bills became the main financing instruments, mandatory holdings of government debt instruments were abolished, and reliance on borrowing from the central bank was sharply reduced. The outstanding stock of treasury bills now amounts to DH 143 billion, spread out over 330 different issuances. The main subscribers are institutional investors, namely CDG, insurance companies, and the OPCVMs. To activate the secondary market, the treasury has concluded agreements with seven financial institutions which committed to act as market makers (IVTs). Nevertheless, the secondary market remains narrow, and is limited almost exclusively to repo-operations.

46. In the absence of organized derivatives markets, the only interest rate markets outside treasury securities are the corporate bond market and the market for negotiable debt instruments (TCNs). The primary market for corporate bonds is rather inactive now that the State no longer guarantees the debts of the CIH and the BNDE, which used to be regular issuers. In 2002, the primary market was limited to nine issues totaling DH 2.1 billion, and on the secondary markets the number of transactions was less than one per day on average during the last two financial years. The corporate bond market is regulated and supervised by the CDVM. The TCN market, for its part, is monopolized by the banks and the specialized credit institutions. Consumer credit and leasing institutions are regular issuers of "finance company bills" (FCBs), but the growth of that market has slowed down significantly as well. The TCN market is well regulated. The various legal and regulatory texts describe issuers' obligations to inform the public, and the reporting requirements to the BAM. The CDVM is responsible for monitoring observance of public information requirements, while the BAM monitors the market.

\section{Infrastructure: Payment and Settlement Systems}

47. The Moroccan payment system is dominated by cash and paper instruments (e.g., checks), although credit and debit card transactions have grown significantly. Clearing transactions are still done manually, resulting in settlement lags for interregional transactions that do not meet the requirements of a modern economy, and there is no realtime settlement system. While reliance on manual procedures reduces systemic risk, it does act as a brake on the development of the financial sector. Two major projects to modernize the system are currently underway: the Moroccan interbank teleclearing system (SIMT) for the Casablanca market started operations in May 2002, and the interbank electronic banking center (CMI) is planned to become operational during the first half of 2003.

48. Maroclear was established in 1997 as central depository and settlement and delivery agent. Maroclear was established by law as a public limited liability company, managed by a board of directors chaired by the Minister of Finance, and overseen by a government commissioner. The law that established Maroclear also introduced paperless 
securities and the posting to accounts of all interest rate securities, shares in listed companies, and OPVCM securities. It vested in Maroclear the regulatory authority and supervisory authority over the maintenance of securities accounting by its affiliates. The settlement and delivery procedures, initially limited to over-the-counter (OTC) operations, were extended to include transactions on the Securities Exchange from March 2002 onward. While Maroclear is majority-owned by the State (directly and indirectly), it could eventually be sold to the private sector, and placed under the supervision of the CDVM.

\section{Regulation and Supervision}

49. There are three major regulatory and supervisory agencies in Morocco, namely the BAM, the CDVM, and the MoF. Although the MoF is involved in all sectors of the financial system, the three agencies" responsibilities are generally not shared. Nevertheless, there are some areas of overlap, generally between the MoF and the others. Table 11 provides an overview of the three agencies" responsibilities.

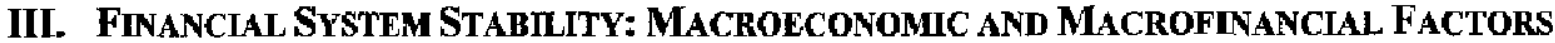

\section{A. Macroeconomic Environment}

50. The Moroccan economy is characterized by the significant share of agriculture in GDP and employment; economic growth that has been volatile and low in per capita terms since the early-1990s; uneven economic development; a fiscal performance that has been unsatisfactory, but a public debt situation that has become less problematic; the continued dominant, albeit reduced, role of the state; and large trade deficits that have been financed with remittances, tourism receipts and capital inflows.

51. Capital account restrictions apply to residents, but transactions by nonresidents are mostly free. The capital account restrictions have allowed the authorities to maintain a pegged exchange rate in combination with an independent monetary policy. Monetary policy itself aims at maintaining price stability, and that ultimate objective is pursued within an informal quantitative framework, using indirect instruments.

52. There is an absence of benchmarks. The closed character of the market removes all extemal references, and the state of the treasury bill markets does not allow the formation of a representative yield curve and benchmark interest rate. This absence of benchmarks risks creating distortions in resource allocation, which in turn could hamper growth.

53. International agreements are transforming the formerly closed nature of the economy. After acceding to the GATT in 1987, Morocco concluded an Association Agreement with the EU in 1996 that aims to establish a free trade area between the signatories by 2012 at the latest. These important agreements have been accompanied by a comprehensive reform drive to liberalize and open up the Moroccan economy.

54. Macroeconomic conditions were strong in 2001-2002. An economic recovery helped the government to exceed its fiscal targets, but deficits remained high. Abundant liquidity conditions reflected continued high remittances and sluggish domestic demand for 
credit, and prompted the BAM to tighten its monetary policy stance, out of concern for excessively low interest rates.

\section{B. Macrofinancial Risks and Exposures}

55. The macroeconomic environment described above does not constitute an immediate vulnerability for the Moroccan financial system, but it has significant costs and holds medium-to-long term risks. The combination of exchange controls, a fixed exchange rate regime, a low degree of openness, and a central role played by the government, protects Morocco from the volatility of global financial markets. In addition, by channeling domestic savings into domestic investments, it provides a captive market for financing budget deficits. As a result, the current macroeconomic framework provides a substantial degree of short-term stability for economic activity. However, this stability comes at a significant cost, primarily in terms of growth and economic development, and it could lead to increased medium to long-term risks. In particular, the increased short-term stability risks allowing fundamental economic imbalances to remain unaddressed for too long, thus doing more structural harm to the economy than they would if correction were forced upon policymakers at an early stage by the disciplining effect of markets and capital flows. The current economic framework also risks rendering the economy less efficient and more vulnerable due to distorted incentives and the resulting suboptimal allocation of resources. Finally, the pressure on policymakers from the social problems created by high unemployment and increasing poverty, could lead to deviations from the economic reform program and to policies that are detrimental to the long-term development of the economy and financial sector.

56. The Moroccan authorities engaged in an economic liberalization process in 1993, with the aim of promoting economic and social development. The process of liberalizing and opening the Moroccan economy has so far been carried out in a determined but cautious manner, as the authorities are aware that certain prior conditions, such as a sound financial system with advanced risk management practices, fiscal discipline and a corporate sector that can compete on a global scale, have yet to be achieved.

57. In this context, two general kinds of risks arise. In the short to medium run, the main risks are related to the deficiencies of the existing system, while in the medium to long run, they stem from the need to liberalize and reform the economy.

\section{Risks related to the current system}

58. Variations in agricultural production, the terms of trade, and competitiveness introduce volatility in the economy, which in turn affects the creditworthiness of borrowers. Erratic developments in agricultural production and international commodity prices are responsible for a volatile economic growth rate and increase uncertainty in financial decision-making. In addition, while the policy of pegging the dirham to a basket of currencies has provided a nominal anchor to the economy, it has led to variations in the real exchange rate and thus in competitiveness. Nevertheless, the real effective appreciation that 
occurred during the 1990 s has been significantly reduced since 2001, and the external position has been further consolidated.

59. Remittances play an important role in the economy and the banking system, but their stability cannot be taken for granted. Remittances help finance the trade deficit, support domestic demand and account for a substantial part (27 percent) of deposits in the banking system. While these remittances have been stable in the past, driven by factors such as culture, family ties, and tax considerations, it cannot be excluded that economic or other developments in Morocco or Europe could trigger a decrease in remittance flows oradmittedly much less probable-even a reversal of those flows.

\section{The prohibition on investing abroad limits the scope for diversification in} investors' portfolios. Private as well as institutional investors are restricted to investing in a very limited range of domestic assets. As a result, portfolios can only achieve a substantially less favorable optimization between risks and returns than what would be possible with the inclusion of foreign assets.

61. Government debt represents a substantial part of the financial system's assets. Partly as a result of the authorities' choice to replace foreign debt with domestic debt, public debt now accounts for 25 percent of the assets of the commercial banks, and 60 percent of those of institutional investors. As a result, the solvency and liquidity situation of the financial system is dependent on the authorities' continued ability to service and roll over its debts, which depends on overall confidence in the authorities" fiscal policy. The latter in turn could be affected by developments in the financial sector, as a result of the implicit and explicit contingent liabilities the authorities have vis-à-vis the sector (e.g., the fiscal costs of the rehabilitation of troubled banks). In addition, although the captive nature of domestic financing has been reduced with the elimination of liquidity requirements and some of the other forms of nonmarket based borrowing, the absence of alternative investments, in combination with state ownership of the main players on the T-bill market, continues to put the treasury in a privileged position as a borrower, which has implications for the profitability, diversity and profile of investors' portfolios.

62. In addition, risks also arise from the transitional nature of the economy. A gradual reform process necessarily means that elements of the former economic system survive and keep on functioning alongside elements of the new system. That could present risks when such elements are not consistent with each other. In the financial sector, for example, risks could arise when the regulatory and supervisory arrangements, and the management and internal control systems of financial institutions, are not consistent with a higher-risk free-market context in which banks have access to developed financial markets.

\section{Risks associated with the need for reform}

63. In the medium to long run, the main macroeconomic risks are related to the dynamics of the economic liberalization process. Liberalization could weaken the quality of the financial system's assets because Moroccan enterprises are insufficiently prepared for the competition from abroad and, indirectly, because the government budget could be 
weakened as a result of lower tax receipts. The financial system would also suffer if a precipitous opening of the capital account would lead to capital outflows and a balance of payments problem. A related challenge is the likelihood that the pegged exchange rate would become unsustainable after liberalization, and that many economic agents (including, perhaps, financial institutions) may be unprepared for an alternative regime, having adapted to the stability of the current environment. If the authorities decided to maintain the peg, it would need to be supported by monetary and fiscal policy, which in turn would likely lead to a greater volatility of the real econony, as the scope for setting macroeconomic policies as a function of domestic considerations would be diminished. Excessive delays in reform would represent other important risks. They would sap confidence, not only of domestic economic agents, but also of the foreign direct investors that have helped finance the balance of payments in recent years. It would also likely lead to a growing gap in technologies, development and know-how between Morocco and the rest of the world, increasing the eventual reform cost.

64. The long-term stability of the financial system depends upon Morocco's successful transition toward integration into the global economy, which itself is dependent on a more balanced fiscal policy. Substantially reducing fiscal deficits (excluding privatization receipts) is critical for the financial system, in order to: (1) minimize the risk of arrears and debt servicing problems; (2) improve the sovereign risk profile and thus reduce the cost of financing for the public and private sectors on international capital markets; and (3) facilitate the financing of the private sector, by avoiding crowding out and high interest rates that could lead to short-term speculative capital inflows.

\section{Systemic Liquidity Arrangements}

65. Although monetary policy has so far accommodated the needs of the treasury and those of the banking system, inflation has stayed low. There have also been coordination problems with fiscal policy, especially with the need to sterilize large lump-sum government revenues from abroad. Nevertheless, inflation has stayed in the 0-3 percent range during the last five years (see Table 17).

\section{Monetary policy now relies on indirect instruments, but it has hampered the} development of the interbank market, and its relevance remains constrained by limits on market forces. As part of its reforms during the 1990s, Morocco introduced indirect instruments of monetary policy, phased out direct credit controls, liberalized interest rates, and eliminated mandatory lending and preferential refinancing rates. Monetary policy now relies on five instruments, namely, a 7-day discretionary facility, a 5-day standing facility, a 24-hour standing facility that automatically covers overdrafts or provides liquidity at the request of banks, a 48-hour standing deposit facility, and reserve requirements. Within this framework, the BAM steers the overall level of liquidity using its 7-day facility. The design and use of these instruments have discouraged banks from dealing with each other in the interbank market, because liquidity can always conveniently be obtained from or placed with the BAM. In addition, the allocation of a large part of the economy's financial resources is not made through market mechanisms, due to the compartmentalization of the financial 
sector and the existence of exchange controls. This, in turn, reduces the impact and relevance of market based monetary policy instruments within the economic policy framework.

67. The interbank market is not very active and is dominated by very short-term operations. Most interbank operations are unsecured and some banks post indicative quotes for periods of up to one year, but there are no market makers authorized by the central bank. The traded volumes are small, at between one and three billion dirham per day.

68. The authorities have indicated that the BAM would not let a bank go bankrupt. BAM's statutes do not obligate it to act as a lender of last resort, even though market participants are convinced that it would do whatever it takes to resolve a banking crisis. The absence of an official framework for handling systemic liquidity crises reinforces the expectation of a bail-out and increases moral hazard among Moroccan financial institutions. The way in which crises have been resolved to date only bolsters that feeling. Moral hazard could be reduced by expressly defining the circumstances and conditions in which BAM would contribute exceptional liquid resources.

\section{VulnERabilities AND SOUNDNESS OF THE FinanCial System}

\section{A. Potential Channels of Contagion: Interlinks Within the Financial Sector}

\section{Cross-ownership of capital}

\section{Ownership links represent a potential channel for contagion within the public} financial system. The past practice of calling upon public institutions to support troubled private financial institutions, has led to substantial exposure of the stronger public financial institutions to the weaker ones. This exposure has come both in the form of equity stakes and credits. Nevertheless, ownership links do not appear to pose a risk of contagion between the public and private finamcial systems, as there are few cases of cross-ownership between the two. The crossed equity interests of the public and private banks do not exceed 2 percent (see Table 12), and remain limited even if the public nonbank institutions are included.

\section{While banks hold equity stakes in a range of nonbank financial institutions,} potential contagion is limited by the small value of these stakes in the banks' books. The private financial system is characterized by the dominance of the banks, which hold major equity interests in the other components of the system. Thus, banks hold 54 percent of the capital of the mutual fund management companies (OPCVMs) and about 57 percent of the capital of the financial leasing companies. As a result, problems in these other components could, in principle, affect the banks. However, these equity stakes only account for a small portion of total bank assets, limiting the risks.

71. The importance of financial conglomerates within the private financial sector holds risks. The three largest groups hold an estimated 25 percent of the capital of the private banks, 22 percent of the mutual fund management firms, 30 percent of the leasing companies, and 58 percent of the insurers. Hence, even if ownership links within these 
groups at present do not appear to be important on the banks' balance sheets, there is a risk that when problems would arise, they could quickly spread throughout a financial group, as the healthy parts are called upon to support the weaker parts. At present, the main potential channel of contagion within these groups is between the insurance and banking sectors.

\section{Operational links}

72. Risks of contagion through the interbank market, debt instruments and bank loans appear small given the low volume and value of transactions. As of end-September 2001 , for example, total interbank exposure among Moroccan banks was only about two percent of the aggregate total assets of the banking system. Exposure between financial institutions through debt instruments and bank lending is in practice small, although there is a certain degree of credit provision through debt instruments and bank loans (see Table 13), mainly from the banks and the mutual funds to leasing companies, which often reflects the cross-ownership ties that exist between these institutions.

\section{B. The Banking System}

\section{Financial soundness}

73. The banking system's financial soundness indicators reveal that the commercial banking sector is globally healthy and growing but that the specialized banking system is in dire straits (see Table 14). The most important factors that might threaten the overall stability of the system include the large amounts of nonperforming loans, the downward trend of interest spreads, the commercial banks' reliance on demand deposits (especially by nonresidents), and the insufficient solvency of the specialized banks. The factors that support the stability of the system include the sustained strong growth of customer deposits, the soundness of the commercial banks, the diversity of the commercial banks' loan portfolios, and the limited financial links between the banks (see also section IV.A).

\section{The solvency situation of the commercial banking system is generally} comfortable, but that of the specialized banking system is precarious. According to data supplied by the BAM, the capital adequacy ratio of the banking system was 12.5 percent at end-June 2002 (see Table 14), well above the prudential threshold of 8 percent. However, this healthy figure is entirely due to the commercial banking system, the solvency of which stands at 15.3 percent. By contrast, the specialized banks average a solvency ratio of just 1.5 percent, in spite of the fact that two of them benefited from recapitalization operations during 2000-2001. In fact, two of the specialized banks were insolvent at the end of June2002 , as were three small public commercial banks. ${ }^{7}$

${ }^{7}$ In June 2002, it was estimated that a recapitalization of the two large specialized banks to the eight percent minimum CAR would cost about one percent of GDP, or about 3.5 percent of the annual government budget. 
75. The banking system suffers from large amounts of nonperforming loans (NPLs), which are concentrated at the specialized banks (See Table 16). The net amount of NPLs (after provisions) on the balance sheets of the specialized banks amounted to 20 percent of total assets at end-September 2002, as compared to only two percent at the commercial banks (see Table 14). This difference is the result of a combination of a much higher gross level (gross NPLs amount to 36 percent of gross loans at the specialized banks, against 11 percent at the commercial banks) and inadequate provisioning at the specialized banks (where provisions amount to 40 percent of gross NPLs, against 70 percent at the commercial banks). ${ }^{8}$ The NPL problems are aggravated by the long delays in the recovery of claims through the courts, a factor which affects commercial and specialized banks alike.

\section{Exposure and asset concentration indicators do not reveal major problems,} although the concentration in financial sector ownership represents a risk. BAM data show that large exposures represent 148 percent of the banks' equity capital (which is below the European prudential limit of 800 percent) and that connected lending totals 29 percent (see Table 14). It should be noted, however, that these figures do not fully take into account the impact of conglomerates, whose weight in the economy could result in risk concentration and connected lending being underestimated. Indeed, a sizable proportion of the large exposures concerns a single private conglomerate, which could constitute a factor of systemic vulnerability. ${ }^{9}$ Nevertheless, in terms of sectoral exposure, the banking system's loan portfoiios appear relatively well diversified. Thirty-eight percent of loans are to miscellaneous services businesses, 19 percent to construction and public works (including residential mortgage loans), 16 percent to the manufacturing sector, 11 percent to agriculture, and 9 percent to the commercial sector. Loans in foreign exchange are negligible, at 1 percent of total lending. Off-balance sheet exposure are predominantly trade-related. Since there are no derivatives markets in Morocco, and capital controls prevent banks from taking sophisticated off-balance sheet positions, the risks related to exposures appear limited.

\section{Moroccan banks generally appear to be well managed, with private domestic} banks in particular pursuing conservative policies. However, the quality of management in the banking sector is impaired by government interference in its own banks, the noncompetitive appointment of managers, relatively undeveloped relations with foreign banks, and by educational constraints in Morocco, particularly in the areas of management, finance, and economics. Most of the large private banks benefit from the presence of foreigners on their boards of directors, but foreigners are not usually to be found at the dayto-day management level, except in the foreign banks. Publicly held banks are often run by

\footnotetext{
${ }^{8}$ It should be noted, however, that these nonperforming loans include loans backed by guarantees and/or collateral.
}

${ }^{9}$ This high degree of risk concentration is the result of a recent merger of two major groups. BAM has asked the merged entity to seek other sources of finance (other than the domestic banking system) in order to reduce the system's exposure. 
managers recruited from the ranks of the civil service. As their banking experience is often very limited, this policy is not without risk.

78. Management efficiency indicators show that expenses, including personnel expenditure, are being kept under control; they are either stable or declining. Overall expenditure has varied between 45 and 50 percent of gross earnings during the past five years (see Table 14). While the number of employees is increasing, this is happening at a slower rate than the growth in assets and branches, suggesting gains in productivity. As a result, revenues per employee are on an upward trend. One risk factor is the strong growth in the number of branches (5-7 percent per year over the past five years). The risk, which has not yet materialized, is that this "competition through branch network growth" would bring costs to a level that is unsustainable for the size of the market, at a time when liberalization would attract lean and efficient foreign or start-up institutions into the market.

79. The banks are generally audited by at least two statutory auditors. The accounts of the large private commercial banks are audited by Moroccan branches of international accounting firms. The auditing standards applied are normally those of the accounting profession in Morocco, which are largely inspired by IAS (see section VI.G.).

80. Despite increased competition and declining interest rate spreads, the profitability of the commercial banking system has been both comfortable and stable over the past five financial years, while the specialized banks suffered significant losses. The commercial banks' return on assets was a remarkably stable 1.1 percent during the past five years, generating a return on equity of between 12.5 and 13.5 percent (see Table 14). Thanks to an increase in commission and fee revenues and good control of operating costs, the overall profitability of the commercial banking system was maintained in spite of declining interest rate spreads. The specialized banks, by contrast, have suffered significant losses since 1998, brought about primarily by a drastic reduction in the assessed quality of their loan portfolios.

81. The interest margin represents the bulk of profits, and is supported by the importance of unremunerated demand deposits. Profitability analysis reveals that the interest margin represents 84 percent in the net banking product of the system (Appendix Table 2), and even almost 90 percent at the specialized banks. Other sources of income, which consist mainly of commissions, remain limited. The analysis further shows the importance of the interest on the government debt in the earnings of the commercial banks, and indicates that the lack of profitability at the specialized banks is the result of a combination of high operating costs and provisions and a low interest margin (see section II.A., para. 34). Interest rate spreads, in particular at the commercial banks, have benefited from the importance of unremunerated demand deposits as a source of funding, but they have been on a downward trend, fueled by an increase in interest rate competition and by an overall decrease in the level of interest rates in the economy, which has reduced spreads over unremunerated demand deposits.

82. The availability of a large and steadily growing pool of deposits requiring little or no remuneration is currently one of the major strengths of the financial system, but 
is unlikely to last. Since 1992, deposits have grown constantly, at an average of 11 percent per year and a minimum annual growth rate of five percent. The banking system has benefited greatly from this, both in terms of profitability and liquidity. However, that leaves the banks vulnerable to changes in this pattern of rising free deposits. Experience from other countries shows that such a situation cannot be sustained in the long term as the financial system develops, and a wider range of competing financial assets becomes available.

\section{The liquidity position of the banking system appears satisfactory, but structural} vulnerabilities exist. Demand assets represent 4.5 percent of the banking system's balance sheet total, or 12 percent of its demand obligations. Adding in short-term realizable assets, such as treasury bills and short-term loans, raises this ratio to 137 percent, which appears comfortable. Nevertheless, a sudden massive withdrawal of demand deposits, triggered for example by a crisis of confidence or a premature opening of the capital account, would likely create severe liquidity problems, requiring the BAM to refinance a large part of the banks' holdings of treasury bills. If monetary or exchange rate policy considerations would prevent it from doing so, the stability of the banking system could be threatened. Commercial banks would be particularly vulnerable in this regard, given their reliance on demand deposits. The situation of the specialized banks is somewhat different. On the asset side, the specialized banks do not have substantial reserves of treasury bills, their loans tend to be longer term, and a fifth of their balance sheet totals is tied up in the form of (net) nonperforming loans. On the liability side, however, their resources are more stable in the short run, because demand deposits represent only 16 percent on average of their balance sheet totals, as compared to 41 percent at the commercial banks. However, in the medium term, they do face a rollover risk related to their borrowing operations.

\section{Vulnerabilities and stress tests}

\section{Stress tests indicate that the main vulnerabilities to which the banking system is} exposed are credit risk, margin risk and, to a lesser extent, transformation risk. The stress tests conducted during the FSAP missions were based on end-2001 data reported by the banks to the BAM. Hence, the validity of the stress test findings is contingent on the reliability of those data. As noted above (see Section I.A., para. 12), there are several factors that could affect data reliability. In addition, it is important to note that stress tests look into the situation of financial institutions at a particular point in time, and that the findings are therefore only valid in the short term.

\section{The main vulnerability facing the banking system is that of credit risk (see} Table 18). This said, the stress tests do not suggest any immediate solvency risk for the commercial banking system as a whole, even if several major, mostly foreign-owned, commercial banks run the risk of seeing their solvency ratios fall below the prudential threshold of 8 percent in the event of a shock of even medium-sized proportions. For example, a shock in which 15 percent of performing loans are classified, and 50 percent of classified loans are downgraded to the next lower classification category, would reduce the solvency ratio of the commercial banking system to 11.6 percent. At the specialized banks, credit risk has already materialized, and the tests show that these banks remain highly vulnerable in the event of further deterioration in the quality of their portfolios. The same 
shock as mentioned above would reduce the solvency ratio of the specialized banks to 3.6 percent. Stress test simulations of sector-specific shocks show no major vulnerabilities at the level of the commercial banks, thanks to the wide sectoral diversification of their loan portfolios. In contrast, the specialized banks are extremely vulnerable to shocks specific to their areas of activity. Stress tests for eight different severe sectoral shocks indicate that the greatest impact on the banking system would result from a crisis in the area of government finance (i.e., domestic arrears), followed by a crisis in manufacturing, a crisis in the construction industry and real estate, and a crisis in export sectors. ${ }^{10}$ In contrast, the banks' loan portfolios generally appear less vulnerable to shocks hitting the phosphates sector, agriculture, remittances or tourism. ${ }^{11}$.

86. Further declines in interest rate spreads would put profitability under pressure. Interest rate spreads have declined steadily over the past five years (see Table 14), and stress tests indicate that a further fall of 100 basis points would, everything else equal, lower the return on equity of the commercial banks from 13.4 percent to 6.5 percent. While tests were not meaningful for the loss-making specialized banks, their potential to return to profitability would be further reduced in a context of lower spreads.

87. The banks are also exposed to transformation risk. As discussed above, the banking system relies heavily on short-term resources, part of which it invests in long-term loans or treasury bills. Other assets are tied up in the form of nonperforming loans and shortterm credits, which are in practice not always redeemable in the short-term. ${ }^{12}$ The commercial banks appear to be vulnerable as a result of the fact that demand deposits account for 41 percent of their balance sheet totals. Transformation risk can materialize in two forms, interest rate risk and liquidity risk.

88. Interest rate risk appears contained. From the perspective of the banking system as a whole, it is estimated that fixed-rate assets exceed fixed-rate liabilities by an amount equivalent to 21 percent of the balance sheet value. Variable-rate assets exceed variable-rate liabilities by an amount equivalent to 12 percent of the balance sheet value. These spreads between assets and liabilities are financed by unremunerated liabilities-essentially demand deposits. This implies that there is not really any rate risk aside from the margin risk described above, provided that demand deposits continue to be stable and unremunerated.

${ }^{10}$ The sectoral test related to government finance looked into the indirect effects of government arrears on the quality of banks' loan portfolios, by assessing the sensitivity of the different sectors of the economy to government arrears. It does not consider the effects on the banks' holdings of government bonds.

${ }^{11}$ The test related to remittances looked into the indirect effects on the quality of banks' loan portfolios of a substantial decline in the flow of remittances.

${ }^{12}$ Moroccan businesses often finance long-term investment projects with short-term credits, which are repeatedly rolled over and/or eventually converted into long-term credits. 
89. The simulations also indicate that there is no systemic risk of short-term liquidity problems, as long as the BAM stands ready to refinance the banks' treasury bills. By refinancing their treasury bills most banks would be able to withstand an almost immediate withdrawal of 20 percent of passbook savings, 25 percent of demand deposits, and 100 percent of interbank deposits. ${ }^{13}$ The only two major banks that would not have sufficient treasury bills have controlling foreign sharebolders that could provide liquidity support. Nevertheless, if structural reforms or other factors were to provoke a structural downturn in demand deposits, liquidity problems could result in the medium term.

90. The importance of treasury bills on the commercial banks' balance sheets implies a high level of vulnerability for the hypothetical risk of a sovereign default. In 2002 , the largest monthly installment payment on treasury bills was equivalent to more than 1.8 times the armual profits of the banking sector and 1.8 percent of all deposits. This vulnerability is concentrated in the commercial banking sector, 24 percent of whose assets are public debt instruments, as against only 6 percent for the specialized banks.

91. The commercial banking system does not appear to be vulnerable to exchange rate risk, whereas the specialized banks are exposed to such risk because of their borrowing abroad. ${ }^{14}$ Tests indicate that a five percent devaluation would result in a small net loss, on average, for the commercial banks, and a net loss at the specialized banks equivalent to 0.7 percent of their assets. In contrast to a few years ago, the State now only covers a portion of exchange rate losses of the specialized banks, but this coverage is not taken into account in these tests. The tests also only measure direct exchange rate risks related to the banks' own exposures to foreign exchange. Indirect exchange rate risk stemming from private borrowers' balance sheets is considered to be negligible given the small share of foreign currency denominated loans in total loans (about 1 percent, see Table 14). Nevertheless, the government is exposed to foreign exchange risk through its external debts, and as a result, banks' portfolios of loans and public debt could be affected indirectly by a foreign exchange shock, through the impact on the government budget.

\section{Nonbank Financial Intermediaries}

92. The main vulnerabilities in the nonbank financial sector are situated at the level of the pension funds, the insurance sector, and the CDG. Minor and potential vulnerabilities are associated with the leasing companies and the emerging microcredit sector. However, it must be noted that data availability issues make it impossible to do as thorough an analysis of vulnerabilities in the nonbank financial system as for banks.

\footnotetext{
${ }^{13}$ Treasury bills cannot be redeemed before maturity at the Treasury itself, but the BAM's standing facilities allow banks to refinance them at any time.

${ }^{14}$ Prudential regulations limit open positions to 10 percent of capital in any one currency, and to 20 percent for all currencies combined.
} 


\section{All pension schemes are in considerable financial disequilibrium. They are} generous, have small contribution bases and low contribution ceilings, and maintain a weak relationship between contributions and benefits. Studies indicate that in the absence of reform, pension schemes in Morocco would register annual deficits of DH130 billion by 2040 , and that the accumulated deficit by then would be equivalent to one year of GDP. The generosity with which pension rights are accrued and the demographic pressure of an ageing population will necessitate an exponential increase in contributions to keep the scheme in balance. Furthermore, the pension funds' portfolios yield less than optimal and are riskier than needed because, in the presence of capital controls, there are limited possibilities for diversification and for investing in long-term bonds, and because management of the pension funds' assets is a near-monopoly of the CDG, whose mandates do not guarantee that the funds will be managed in the best interest of the (future) pensioners. In fact, the pension reserves have in practice been used as captive funds for financing the government budget. Finally, the Moroccan pension system could be exposed to political risk owing to the tripartite nature of its decision-making bodies, whose composition and mandates are such that their independence cannot be guaranteed.

94. The insurance sector has been rehabilitated since 1995, when five small insolvent companies were liquidated, but over-reliance on capital gains constitutes a vulnerability. The insurance companies mostly respect prudential regulations. However, several companies have chronically failed to observe regulatory requirements on technical reserves, for which the only-unused-means of enforcement available to supervisors used to be license revocation. The new insurance code adopted by parliament in June 2002 provides for more finely tuned intermediate measures. The sector's profitability has been high in recent years. For financial years 1999 and 2000, profits amounted respectively to 60 percent and 20 percent of equity capital. However, profits were generated entirely from exceptional gains on sales of securities, while premiums were insufficient to cover the damages paid and operating costs. Thus, the sustainability of profitability is in question, especially in the context of a bear market. At end-2000, investments in shares and bonds represented almost 58 percent of the total assets of the insurance sector. Although this is in line with international norms, the value of this portfolio may be affected by the weight of insurance companies in the volume of transactions on the market, as well as by a low degree of diversification ( 82 percent of the portfolio is invested in securities of financial, investment, and holding institutions) and a relatively high number of cross-holdings.

95. The CDG has been weakened by its use to support public policy goals, and in particular, by its support for troubled public financial institutions. In practice, the CDG has been given two mutually inconsistent sets of tasks. On the one hand, it is supposed to prudently manage the funds of its clients, and on the other hand, it is expected to use the funds it manages, as well as its own funds, to support public policy goals. These inconsistent tasks hold significant risks, in the sense that CDG could lose institutional investors' money and/or the trust of its clients. The CDG currently has to cope with stagnating institutional savings coupled with a gradual immobilization of a portion of its assets, because of the volume of its equity holdings and the role it has played in supporting other public institutions. At end-December 2001, its claims on the former OFS's exceeded twice its equity capital. These investments could run counter to the interests of institutional depositors, whose 
assets are already in part invested in projects with a modest profitability level. It therefore seems advisable to avoid involving the CDG in the restructuring of banks or other companies in the future. More generally, the CDG would benefit from a formal distinction between its commercial activities and public services, perhaps by establishing specific subsidiaries, in order to resolve the inconsistent expectations placed on it.

96. While alt financial leasing companies are reported to be in compliance with prudential requirements, development of the sector has met with some obstacles. The existence of a maximum rate regulated by the BAM (the "usury rate") excludes certain potential customers that are deemed too risky, the underdevelopment of scoring limits the proper assessment of risks, higher than average taxation puts the sector at a competitive disadvantage, and the need to acquire non-amortizable land in order to guarantee the possession of the buildings located on it ties up their assets. ${ }^{15}$ The sector also suffers from a shortage of long-term financing as banks cannot lend them more than 20 percent of their capital.

97. Although in view of its size, the activities of the microcredit sector do not constitute a systemic risk at this stage, its rapid growth, against a background of inadequate regulation and supervision arrangements, merits greater attention. Effective implementation of the decisions already adopted in the areas of regulation and supervision (accounting system and ratios) would significantly reduce the potential risks.

\section{Securities Markets}

98. A sustained decline in the level of activity on the securities market poses a longterm threat to the viability of securities brokerage firms and the Securities exchange itself. Since end-1998, the combined effects of the end of a reform-driven bull market, a less favorable macroeconomic climate, the withdrawal of foreign investors from emerging markets, and the introduction of a capital gains tax have led to price declines that have persisted to this day. The price declines went hand in hand with a decline in liquidity that brought the market back to the activity levels observed in 1995, even as the capitalization of the securities market had grown by a factor five and the number of listed companies increased from 44 to 53 . The decline in share prices and trading volumes cannot be explained by the profitability outlook of the listed companies alone, but reflect a general loss of confidence in the market. Exogenous factors aside, the revitalization of the market will require a comprehensive reform strategy aimed at simplifying the legal and regulatory framework, by expanding the responsibilities and autonomy of the institutions around which the market revolves (the CDVM, the SBVC, and Maroclear). To this end, the authorities have

${ }^{15}$ Under Moroccan law, the owner of land is also the owner of all the structures on it, obliging the leasing companies to purchase land which they cannot then depreciate. 
prepared a draft law that revises the responsibilities and prerogatives of the CDVM and increases its powers to apply penalties, which had, up to now, been limited. ${ }^{16}$

99. Structural factors pose constraints on the development of the market. The absence of consolidated accounting hampers the transparency of the accounts of listed companies, extensive cross-holdings limit the development of the securities market by reducing the potential for portfolio diversification, and company directors often prefer to resort to bank credit in order to maintain tight control over their companies. In this context, the privatization program offers a unique opportunity to improve the liquidity of the market by increasing the supply of securities in large companies. Similarly, tax incentives to promote the flotation of securities held by venture capitalists could contribute to a revival. Draft regulations on venture capital are currently under consideration at government level.

\section{E. The Offshore Financial Sector}

100. Offshore banks are subject to certain regulatory provisions under the law, but these are rarely enforced in practice. Among other things, observance of the "know your customer" requirement is not checked by external auditors and the prescribed structural ratios have yet to be defined by the Minister of Finance. The sector presents a risk of contagion to the onshore banks, and could be abused for money laundering and terrorist financing. Therefore, the authorities should urgently bring this sector under the close supervision and regulation of the BAM, as well as under the coverage of future legislation to combat money laundering and the financing of terrorism.

\section{Regulation, Supervision, Crisis Management, and Safety Nets}

\section{A. Banking System}

\section{Regulation and supervision}

101. Although the banking sector's prudential framework has been significantly strengthened in recent years, additional measures of a legislative, regulatory, and organizational nature will be necessary within Bank Al-Maghrib (BAM) to improve observance of the Basel Core Principles for Effective Banking Supervision. During the past few years, the regulatory and supervisory framework has, in fact, improved. A new bank chart of accounts was introduced, regulations on internal control were adopted, and certain prudential rules have been amended or introduced, including on external audit. In addition, the entry into force in 2001 of a regulation on financial penalties should enable BAM to exert greater pressure on supervised institutions so that future infringements of the major prudential rules, including those relating to loan classification and provisioning, would be punishable by a specific fine. In spite of this progress, however, important weaknesses remain, including the limited independence of bank supervision, the lack of efficiency of on-

${ }^{16}$ To this day, no securities market crimes have ever been prosecuted in Morocco. 
site and off-site supervision, the weaknesses of the AML framework and shortcomings in the regulations on loan loss provisioning.

102. Further improvements are necessary to enhance the effectiveness of banking supervision. In terms of supervision strategy, it is essential that BAM reach decisions on the respective roles to be played by off-site inspections, on-site inspections, and external auditing. At the institutional level, the reform of the banking law, which is currently under discussion, should clearly emphasize the independence of the BAM vis-à-vis the MoF in respect of preparing prudential and supervisory regulations. In the legal and regulatory area, the loan classification and provisioning system would benefit from a revision aimed at gaining a better understanding of the real risks to which credit institutions are exposed. The BAM's powers to apply coercive measures (authority to forbid the distribution of dividends, etc.) also need to be enhanced, and crisis management mechanisms should be reconsidered (see below). Operationally, effective supervision requires staffing increases and staff quality improvements. Finally, as regards the internal organization of BAM's Credit Institution Directorate, priority should be given to formalizing procedures for analyzing the overall position of all banks with external auditors.

\section{Guarantee and crisis management procedures}

103. While the Moroccan authorities have a range of legal tools at their disposition to address banking crises, these are unsatisfactory. The authorities have so far succeeded in avoiding the liquidation of problem institutions and preventing contagion, despite difficulties experienced by several public and private banks. They have done so by intervening directly, injecting budget funds (DH 2.27 billion for CIH and CNCA between 1998 and 2001), but above all indirectly, by guaranteeing bonds issued by problem institutions and by providing financial support (bond purchases and contributions to equity) through governmentcontrolled institutions (CDG and BCP). Although this approach may have succeeded in preventing liquidations, it is far from satisfactory.

\section{The detection, diagnosis and management of banking sector difficulties have} been hampered by a dearth of supervisory resources, past delays in applying penalties, and a fragmentation of responsibilities. Responsibilities are shared between the Minister of Finance, the governor of the BAM, and, on an advisory basis, the Credit Institutions Committee, resulting in slow and difficult decision-making. In many areas the final decision rests with the Minister of Finance, which introduces an undesirable political dimension in dealing with problems in a banking system that aspires to be predominantly private but where public institutions remain important.

\section{The authorities' role in the resolution of banking crises has been less than} transparent and often excessive. Thus: (i) the market solidarity mechanism forces healthy banks to support their poorly managed competitors and discourages foreign investment in the Moroccan financial system; (ii) the Minister of Finance's right to order the Deposit Guarantee Fund to lend money to a problem institution (see below) entails the risk that funds that are intended to protect depositors could be lost; (iii) the practice to use public financial institutions to shore up problem institutions risks spreading and deepening banking system 
problems rather than resolving them; (iv) the five-year exemption from prudential rules granted recently to a number of troubled public institutions (without a specific schedule for their gradual return to observance of standards at the end of the five year exemption period) erodes the supervisor's authority and creates distortions in competition; and (v) transparency is also called into question by the capital and management ties that exist between the BAM and the public financial institutions. ${ }^{7}$

\section{Deposit guarantee}

106. The banking law has created a Deposit Guarantee Fund, which is managed by the BAM and financed by annual contributions from the banks, based on their level of deposits. The Fund is not a legal entity, but simply an account opened on the books of the BAM, which invests the funds in treasury bills. The estimated value is $\mathrm{DHI} .8$ billion, and no withdrawals have been made since it was opened. By decision of the Minister of Finance, the Fund can cover deposits made by individuals or legal entities up to a limit of DH50,000 (US\$4,400) per depositor, with no particular restriction. It can also, subject to the existence of a recovery plan and after consultation with the Credit Institutions Committee, grant reimbursable assistance to troubled institutions.

107. This mechanisin could be substantially improved. In particular, it would be useful to: (i) clarify the manner in which depositors are to be indemnified; (ii) transfer the decision to use the Fund to the governor of BAM; (iii) keep the banks informed on a regular basis of the Fund's financial position; (iv) eliminate the possibility of using the fund to grant advances so as to avoid the risk of finding the Fund depleted of resources in the event of a bank failure; and (v) reform the structure of the Fund, making it a legal entity and entrusting its management to the banks themselves, with strict rules for the use of its resources.

\section{B. Nonbank Financial Institutions}

108. An evaluation of compliance with the core insurance principles of the International Association of Insurance Supervisors (IAIS) showed that there remains scope for improvement of insurance supervision. The main weaknesses identified were in the areas of internal governance, internal control, asset and risk management and information-sharing with foreign supervisory agencies (see Section II, Chapter ID).

\section{Financial Markets}

An assessment of the IOSCO principles found that there are weaknesses in the regulation and supervision of the securities industry in Morocco. Among the main areas where improvement is needed are the regulatory and supervisory powers and the institutional

${ }^{17} \mathrm{BAM}$ holds 10 percent of $\mathrm{CH}$ and has a seat on the boards of directors of the $\mathrm{CNCA}, \mathrm{CIH}$, and FEC, as well as on the supervisory boards of CDG and CCG. 
set-up of the CDVM, the protection of minority shareholders, and the licensing mechanisms for OPCVMs and market intermediaries (see Section II, Chapter III).

\section{LEGAL FRAMEWORK, INFRASTRUCTURE, AND GOVERNANCE}

\section{A. Legal Framework}

109. While considerable progress has been made on the legal front, a number of challenges remain. A program of legal reform has been in process since 1998. In the first stage of this program, commercial courts were being created to improve the resolution of commercial disputes. As a further step, the Ministry of Justice is now working on the introduction of a legal framework for arbitration, which could play an important part in easing the burden of disputes before the commercial courts. In spite of this progress, however challenges remain, including the insufficient scope for regulations, as opposed to law, in the administration of the financial sector, and the limited regulatory power that has been given to decision makers in the field. Addressing these challenges would help reduce the perception that the concentration of regulatory powers at a ministerial level is a constraint. Furthermore, to be successful, the current legal reform program will need to be extended to the entire judicial sector, rather than remaining limited to the commercial courts.

\section{The law on loan guarantees could be improved by incorporating new and} nexible instruments that facilitate the mobilization of loans and their recovery, and by allowing for the use of movable assets as collateral. Moreover, the system of guarantees, currently spelled out in a series of separate legal and regulatory provisions, could be codified. Progress in this area would enable financial institutions to make credit available to an increasingly wide range of customers, at a lower risk and on more favorable terms.

\section{The implementation of the bankruptey law is hampered by long delays and by} the inexperience of magistrates. The Commercial Code has adopted a modern approach to the bankruptcy of enterprises, by giving priority to recovery and salvage efforts before bankruptcy is formally declared. The role of the judge is pivotal in this process and is evolving toward greater concem for economic necessities. However, according to economic agents, judges still lack commercial expertise and an understanding for the economic needs of enterprises. The legal system also continues to suffer from long delays, notwithstanding the introduction of commercial courts and the efforts made to train magistrates.

\section{B. Anti-Money Laundering and Combating the Financing of Terrorism}

112. Moroceo has not yet criminalized money laundering or the financing of terrorist activities. In spite of having ratified the 1988 UN Vienna Convention in 1992, it has yet to take concrete steps to implement anti-money laundering provisions. A committee comprised of the Ministry of Finance, the Bank Al-Maghrib, and the Foreign Exchange Office has conducted a study and recommended that the authorities sign up to the relevant intemational treaties, introduce legislation to criminalize terrorist financing and money laundering, and establish a financial intelligence unit (FIU). The authorities are considering these measures. 
113. The recommended legislation will have to be implemented in all risk sectors, and adequate resources and training on AML/CFT issues will be required. To be effective, the legislation will need to cover the entire financial system, and adequate resources and training on AML/CFT issues will have to be provided to the supervisory agencies, the FIU, the judiciary, law enforcement agencies and the financial sector. The role of external auditors and compliance officers in financial institutions should also be strengthened to include AML/CFT issues.

\section{Corporate Governance}

114. Morocco has made major progress in improving corporate goveruance, especially at the legislative level. However, good corporate governance requires not only well conceived regulations, but also the effective application of these regulations by supervisors and by the courts. At present, the powers of the securities regulator (CDVM) are too limited to address corporate governance issues. The authorities are reviewing this situation and expect to amend the law.

115. It is recommended that Morocco develop a code of best practices in corporate governance and require corporations applying for a listing on the securities exchange to divulge the extent to which they observe this code. The creation of an institute for board members of Moroccan corporations is also recommended. Such an institute would fulfill a centralization role similar to what has happened in other Code-Civil based jurisdictions.

\section{Payment Systems}

116. An assessment of the CPSS Core Principles for Systemically Important Payment Systems found important deficiencies. Among the main weaknesses were unresolved technical and legal issues, the absence of a well-defined role for the BAM in payment systems-related matters, coordination problems between the main stakeholders, and the absence of mechanisms to limit the risks faced by participants in the system (see Section II, Chapter IV).

117. A global and cohesive reform plan for payment systems needs to be designed within an appropriate institutional framework and in coordination between the various stakeholders. Policy definition and definition of surveillance systems and payment media needs to take place within the BAM. The central bank law should define the scope of the BAM's policy-setting and supervisory roles on payment systems, and these roles should be entrusted to a multidisciplinary team within the BAM. In addition, there is a need for coordination and dialogue between all players, in order to define a plan for the modernization of Morocco's payment infrastructure in the medium term. The creation of a Payment Systems Council would help arrive at a consensus.

\section{E. Public Debt Management}

118. Overall, the management of Moroceo's public debt appears to be in line with internationally accepted guidelines. Government policy is set out annually by the Minister 
of Finance, who establishes general debt management targets as well as more technical objectives. This formalized planning and implementation of policies made it possible to limit the overall level of public debt to 75 percent of GDP at end-2001 and replace external with domestic debt.

\section{The public debt market could be further improved through a number of}

initiatives. There is a need to improve the auction procedures and preannounce the amount to be auctioned during a particular session; develop liquidity through a standardization of shortterm notes and the creation of benchmarks; and develop the secondary market. In addition, the IVTs should be made more dynamic, including by strengthening the resources at their disposal and the controls exercised by the treasury on their internal organization.

\section{F. Transparency of Monetary and Financial Policies}

\section{An assessment of the IMF's Cade of Good Practices on Transparency in} Monetary and Financial Policies identified several areas in which the transparency of monetary policy could be improved. The transparency of monetary policy is currently hampered by a number of legal and institutional features, including the absence of central bank independence and accounfability, weaknesses in the central bank law, and the fact that equity and management links exist between the BAM and the banks it is supposed to supervise. To address these weaknesses, it would be particularly useful to further clarify the central bank's ultimate objective, to better define responsibility for exchange rate policy in the law, prohibit direct participation by the BAM in the capital or management of financial institutions, publish systematic assessments of the results of monetary policy, increase openness about the criteria for appointing and removing members of the BAM board of directors, clarify the role the BAM is expected to play in the case of a major banking crisis, institutionalize arrangements for public accountability, and have the central bank accounts audited by an independent auditor.

121. The transparency of financial policies is hampered by similar problems, as well as by the often unclear delineation of responsibilities between the MoF and other agencies. Financial supervision could be undermined by fragmented responsibilities between the supervisory body and the policy authority (MoF). The transparency of financial policies could be enhanced by the introduction of a formal presumption in favor of public consultations for substantive changes in regulations, and by supervisory agencies producing more informative annual reports.

\section{G. Accounting and auditing}

\section{Morocco's accounting and auditing framework is largely inspired by} International Accounting Standards (IAS), but weaknesses exist due to implementation issues and the omission of certain standards. An assessment of Morocco's accounting and auditing standards and practices that took place in parallel with the FSAP found that financial statements in Morocco generally include most of the necessary information, but that their usefulness and transparency was reduced by weaknesses in disclosure standards and publishing mechanisms. It also found that the legislative framework for the accounting 
profession is adequate, but that significant implementation issues exist, as a large number of chartered accountants do not observe Moroccan standards.

\section{Challenges and Opportunities for Future Deyelopment of The System}

\section{A. Future of the Specialized Banks}

\section{The financial soundness of the public specialized banks has been compromised} by an increased exposure to competition, poorly managed development and diversification, economic shocks, and the embezzlement of funds. Despite warning signs, no timely corrective measures were taken, as a result of which nonperforming loans today represent at least 40 percent of the former OFS's total gross loan portfolio. Moreover, these institutions do not have a sufficiently broad depositor base and have been obliged to resort to more costly forms of financing.

\section{Their present insolvency cannot be allowed to continue, especially since} international experience suggests that the costs of restructuring a bank generally increase over time. The public authorities are currently considering the future of these institutions, with the assistance of the EU, and they should seriously consider the possibility of liquidation. Should they decide not to liquidate, it is necessary that any public missions that the State wishes to confer upon credit institutions be covered by clear and transparent budgetary procedures. The competitive part of their activities must have a credible business plan, respect prudential regulations, find a shareholder base that is predominantly private, and be governed according to objective risk management and profitability criteria.

\section{B. Fostering the Development of the Financial System}

125. The development of the financial system can be fostered through the creation of an environment that is supportive of financial activities. To that effect, the authorities need to extend efforts already underway in the legal and judicial areas, among other things by introducing more expeditious conflict- and problem-solving procedures, such as arbitration and amicable settlements, and by improving collateral recognition. The central bank should also work with professionals in the area of payment systems, to develop modern means of payment (credit cards and interbank cards) and a large value settlement system. The effectiveness of monetary policy could be strengthened through increased central bank autonomy, accompanied by a clear policy mandate and transparency rules. The introduction of a new, well-defined, monetary policy framework should also allow more scope for interbank activity.

126. The authorities should also take steps to ensure the long-term development of financial intermediation. Financial intermediation requires sound financial statements and thus a well-developed accounting and auditing framework. Credit provision would also be facilitated greatly by the establishment of databases on bad debtors, which would encourage stronger borrower discipline. More generally, information and education initiatives are 
needed to develop awareness and a stronger financial culture among professionals as well as the general public. 


\section{SEction II-OBSERVANCE OF FINANCIAL SYSTEM STANDARDS AND CODES: SUMMARY ASSESSMENTS}

This section contains summaries of the reviews of adherence to and consistency with major international standards and codes relevant for the financial sector. Specifically, it reviews compliance with (a) the Basel Core Principles for Effective Banking Supervision; (b) the Intemational Association of Insurance Supervisors' (IAIS) Insurance Core Principles; (c) the International Organization of Securities Commissions' (TOSCO) Objectives and Principles for Securities Regulation; (d) the Committee on Payment and Settlement Systems' (CPSS) Core Principles for Systemically Important Payment Systems; and (e) the IMF's Code of Good Practices on Transparency in Monetary and Financial Policies.

The detailed assessments for each of these standards and codes formed an integral part of the FSAP and an input into the FSSA. ${ }^{18}$ They have helped to identify the extent to which the supervisory and regulatory framework has been adequate to address the potential risks in the financial system. It has also provided a source of good practices in financial regulation and supervision in various areas.

The detailed assessments of standards were undertaken based on a peer review process, as part of the FSAP missions, This section contains a summarized version of the assessments included in the FSAP report.

${ }^{18}$ The Basel Core Principles were issued in September 1997 and the Core Principles Methodology was released in October 1999 by the Basel Committee on Banking Supervision. The MF Code of Good Practices on Transparency in Monetary and Financial Policies was adopted by the Interim Committee in September 1999 and the supporting documentation was approved by the Executive Board in July 2000. The draft Core Principles for Systemically Important Payment Systems, including the methodology were issued for comments in December 1999. The final set of principles was issued in January 2001. The IOSCO Objectives and Principles were issued in September 1998 and a detailed selfassessment methodology is being developed. The IAIS Supervisory Principles were issued in September 1997 and a self-assessment program has been developed to assist the members in evaluating compliance. 


\section{Summary Assessment of Observance of the Basel Core Princtples for EFFECTIVE BANKING SUPERVISION}

\section{A. General}

127. The evaluation of the effectiveness of banking supervision, conducted in February and May 2002, was based on the methodology of the Basel Committee's core principles for effective banking supervision. Although the compliance of the Moroccan supervisory system was evaluated against all the criteria, core and noncore alike, defined in the Basel methodology, the ratings apply only to the core criteria. This evaluation was undertaken as part of the FSAP for Moroccs, and reflects the situation as of May 2002. It does not take into account any legal or regulatory changes that may have taken place since then.

128. In-depth discussions were held with the Credit Institutions Supervision Directorate (DCEC) of the BAM, as well as with representatives of banks and audit firms. Consistent with the Basel methodology, the evaluation was conducted by two examiners (Messrs. Alain Laurin of the World Bank and Baddredine Barkia of the Central Bank of Tunisia who were given unrestricted access to working documents of the DCEC. The mission enjoyed a close and open dialogue with BAM staff, and was therefore able to accurately measure the effective degree of implementation of supervisory instruments, to evaluate the supervisory process and to identify the major areas where improvements could be made.

\section{Background}

129. The BAM has the power to exercise on-site and off-site supervision over the activities of credit institutions and their subsidiaries, and over their compliance with laws and regulations. The BAM is also empowered to issue directives and general circulars to enforce certain provisions of the banking law and its regulations. In this context, the BAM has a particular responsibility to establish the conditions for enforcement of decrees by the Minister of Finance relating to the activities of credit institutions and their supervision. The granting and revocation of licenses is in the hands of the Minister of Finance, although the Credit Institutions Committee must be consulted in these cases. The Moroccan legal system has undergone profound changes in recent years. Several laws have been amended (the law on corporations, the commercial code, the competition law, etc.). At the same time, efforts have been made to streamline the operations of the courts, in particular with the creation of the commercial courts in 1997. The commercial registries have yet to be reformed and financial legislation must still be harmonized.

\section{B. Main Findings}

130. In recent years, the BAM has made substantial efforts to equip itself with the essential tools necessary for effective banking supervision. At the legal and regulatory levels, these efforts have included: (i) the design and implementation of a new Chart of Accounts for Credit Institutions (PCEC), which, however, has yet to be put to full use; (ii) internal control regulations, adopted in 2001; (iii) the Circular of June 19,2001, which allows the BAM to impose financial penalties for failure to comply with the key prudential provisions; (iv) draft 
reforms to the banking law, aimed at strengthening the role of the BAM in banking supervision, and giving it greater independence from the MoF; (v) the recent reorganization of on-site inspection work, which is intended to facilitate the supervision of banking groups; (vi) computerization of the DCEC which makes it possible to access nearly all accounting documents called for in the PCEC and to use standardized statements; and (vii) a substantial increase in the training budget.

The following is a summary evaluation of the 25 principles.

\section{Objectives, independence, powers and resources (principle 1)}

131. While the BAM has a key role as the supervisory authority, the MoF retains extensive powers over licensing, regulation, and penalties. A clarification of the respective roles of the BAM and the MoF, with a view to strengthening the independence of the BAM, is now under consideration as part of a review of the banking law. The draft law would also redefine the roles of the Credit Institutions Committee and the Credit Institutions Commission, whereby the first body (CEC) would be responsible for licensing and regulation, and the second (CDEC) would have exclusive authority over disciplinary questions.

132. In terms of human resources, a cutback in recruitment in recent years has left the banking supervision department of the BAM (DCEC) with a shortage of staff and an unbalanced age structure. In effect, there are only about $30 \mathrm{staff}$ members available for supervising 21 banks and 50 finance companies. On the other hand, steps have recently been taken to equip the DCEC with adequate equipment and computer resources.

\section{Licensing and structure (principles 2-5)}

133. Licensing procedures are largely consistent with the Basel principles. Licensing applications are processed by the CEC, which then advises the Minister of Finance on the decision to be taken. The Law also requires approval, under the same conditions, for any merger or takeover. The MoF may refuse to grant a license, despite a favorable opinion of the CEC. On the other hand, the MoF is bound by that advice if it is unfavorable or recommends certain conditions. The decision to revoke a license also rests with the MoF.

\section{Prudential regulations (principles 6-15)}

134. The regulatory and prudential framework has been improved substantially in recent years. Several laws have been introduced or amended. Other initiatives now under way should strengthen prudential control significantly.

135. With the regulations on internal controls that were adopted in 2001 (principle 14), the BAM should now overhaul supervisory conditions for credit institutions, to pay more attention to their operations and governance. Until now, off-site supervision has focused primarily on audits of accounts, while on-site inspections have been essentially limited to examining the loan portfolio and the adequacy of provisioning. 
136. There are plans to reform regulations dealing with the classification and provisioning of loans (principle 8).

137. Because staff shortages limit the frequency of on-site inspections, external auditors (principle 14) were expected to play the role of "delegated supervisors" ["auxiliaires de supervision "], although the specific responsibilities associated with this function, and the manner in which it was to be performed, were never clearly defined. Now that, according to a draft circular, the role of external auditors is to be strengthened, it is essential to define clear objectives setting out the conditions under which the prudential authorities intend to conduct their work.

138. In terms of money laundering (principle 15), there is no specific legislation governing the participation of financial institutions in combating financial crime. However, in October 2001 Morocco adopted resolution No. 1373 of the U.N. Security Council on combating the financing of terrorism. Furthermore, a committee consisting of representatives of the MoF, the BAM and the Foreign Exchange Office has been made responsible for proposing measures in this area. The circular on internal controls (Articles 68 and 69) requires credit institution managers to take proper precautions and measures to prevent their institutions from being involved in any way in financial transactions related to unauthorized activities and, more generally, to prevent any situation from arising that might tarnish their reputation or that of the banking sector.

\section{Methods of ongoing banking supervision (principle 16-20)}

139. The BAM is responsible for both on-site and off-site supervision (principle 16). Due to staff shortages, on-site inspections tend to have limited objectives and are conducted only infrequently (every five or six years, on average). With the recent introduction of a new chart of accounts, the DCEC is currently working to establish evise supervisory procedures consistent with the new environment, so as to make maximum use of the information collected (principle 18).

140. The circular on internal controls, as well as the circular now being finalized on external audits, should help to reform the architecture of the overall prudential supervision system. In terms of supervisory strategy, these circulars affect the functions of off-site inspection, on-site inspection and external auditing (principle 19). Inspectors will now be responsible for assessing the quality of internal controls and the work of external auditors. Finally, given the demands that these regulations entail, the BAM will have to intensify its contacts at different levels of bank management as well as with the external auditors (principle 17).

141. With the adoption of the chart of accounts and the rules on consolidation for financial institutions, the DCEC has changed its internal organization in order to supervise banking groups on a consolidated basis (principle 20). 


\section{Information requirements (principle 21)}

142. The adoption and introduction of a new chart of accounts for banks has allowed credit institutions to rationalize their information systems, and has enabled the BAM to adapt its own processing systems. This should lead to improvements in the reliability of information and supervision procedures.

\section{Formal powers of supervisors (principle 22)}

143. The BAM has wide legal powers (principle 22) to force banks to take the necessary measures to comply with prudential regulations to protect depositors. The most severe penalties (restriction of activities, revocation of licenses, appointment of provisional administrators) are pronounced by the Minister of Finance, on the recommendation of the governor of the BAM, and with the advice of one of the two advisory bodies (CEC and CDEC). In the case of problems with state-owned banks (e.g. OFS), the BAM's action may be hindered in some circumstances by its lack of independence. The adoption in 2001 of financial penalties should allow the BAM to exert stronger pressure on banks, since violations of prudential regulations will now result in the imposition of penalties. The revisions to the banking law should also equip the BAM with a broader range of tools for action.

\section{Recommendations}

144. The improvement of banking supervision will require a strategic review and a clearer definition of operational objectives. This will mean assessing the respective contributions of off-site controls, on-site inspections, internal controls in the banks, and external audits. Action on this front is urgent, since existing controls are exercised infrequently - at intervals of more than five years - and the recruitment rate at the DCEC (limited to five agents over the last five years) has left supervisory staff shorthanded. The BAM has prepared a draft circular on external audits of financial institutions, setting out licensing requirements for external auditors and expanding the scope of their duties so as to increase their responsibility and their contribution to supervision.

145. The BAM should focus its efforts on the following areas:

Increase staffing for the DCEC.

- The role of off-site supervision should be redefined in light of recent changes (PCEC, consolidated supervision, internal control regulations); it is especially essential to specify operational objectives and procedures for the off-site supervision office so that it can centralize and analyze all available information (accounting data, inspection reports, external audit reports, internal control reports) and thereby obtain an overview of the situation of each bank and the risks to which it is exposed.

- Formalized and institutionalized direct contacts between the DCEC and bank managers and external auditors. 
- Determine the training needs of supervisors for mastering the more complex banking techniques used by some banks (market operations). Ensure that the BAM has sufficient human resources to assess all the risks taken by the banks.

- Review the regulations on overdue loan classification and provisioning in order to assess the real risks that the banks are running. This work is underway.

- Amend the banking law and the charter of the BAM to give it greater independence.

- Negotiate cooperation and information-exchange agreements with other national supervisory bodies (CDVM and DAPS) and with banking supervisors in other countries.

- Expand the field of banking supervision-prudential and supervisory regulation-to include offshore banks.

Table 1 summarizes the main recommendations for improving banking supervision: 
Table 1. Main Recommendations of the BCP Assessment

\begin{tabular}{|c|c|}
\hline Principles & Recommendations \\
\hline 1 & $\begin{array}{l}\text { (a) Strengthen the BAM's independence and powers vis-à-vis the MoF (clarify the } \\
\text { respective responsibilities of the BAM and the MoF, procedures for dismissing the } \\
\text { governor, etc.). } \\
\text { (b) Amend the respective powers of the CEC and CDEC. } \\
\text { (c) Establish cooperation mechanisms with other supervisory authorities, including } \\
\text { counterparts abroad. } \\
\text { (d) Amend legislation to strengthen the role of external auditors (expand their } \\
\text { responsibilities, give the prudential authorities disciplinary powers over external } \\
\text { auditors, etc.). } \\
\text { (e) Increase staffing for the DCEC and provide the necessary training. }\end{array}$ \\
\hline 6 & $\begin{array}{l}\text { Consider the possibility of calculating capital adequacy requirements as a funtion } \\
\text { of the risk profile of each bank. }\end{array}$ \\
\hline 8 & Revise regulations on the classification and provisioning of loans. \\
\hline 9 & Overhaul the risk assessment office to make it more useful to the DCEC. \\
\hline 14 & Define a methodology for evaluating internal controls. \\
\hline$\overline{15}$ & $\begin{array}{l}\text { (a) Define a specific regulatory framework with respect to money laundering. } \\
\text { (b) Subject offshore banks to prudential supervision. }\end{array}$ \\
\hline 16 & $\begin{array}{l}\text { (a) Define operational objectives for on-site and off-site supervision in light of the } \\
\text { supervisory strategy. } \\
\text { (b) Define a methodology for evaluating the banking sector as a whole (ratings, } \\
\text { etc.). }\end{array}$ \\
\hline 17 & Develop contacts with bank managers at various levels. \\
\hline 19 & $\begin{array}{l}\text { (a) Make proper arrangements for the licensing of external auditors of banks by the } \\
\text { BAM, and make their prudential duties specific, and regulated in line with the } \\
\text { legislation currently under preparation. Establish an appropriate framework of } \\
\text { incentives and penalties for external auditors of banks to ensure enforcement. } \\
\text { (b) Develop a methodology for evaluating the work of external auditors. }\end{array}$ \\
\hline 22 & $\begin{array}{l}\text { Strengthen the powers of the BAM and the CDEC (sanctions, appointment of } \\
\text { provisional administrators, suspension of dividend distribution, etc.). }\end{array}$ \\
\hline
\end{tabular}

\section{Summary Assessment of ObServance of the IAIS Insurance Core Principles}

\section{A. General}

146. This assessment of insurance supervision in Morocco was conducted as part of the FSAP missions that took place in February and May 2002. The principal objectives of the assessment were to deternine the degree of observance by Morocco with the core principles of the IAIS and to make recommendations for improvements. The assessment reflects the 
situation as of May 2002 and does not take into account any legal or regulatory changes that may have taken place since then.

147. The MoF is responsible for "regulating and supervising the activities of insurance and reinsurance companies and their capitalization." 19 The $\mathrm{MoF}$ reports to the King and to parliament pursuant to Article 60 of the Constitution. It is responsible for supervising intermediaries (general agents and insurance brokers). The Insurance and Social Security Division (DAPS) of the MoF is responsible for the administration of supervision. The acronym MoF will be used throughout this report for the sake of simplicity and to avoid confusion, since the MoF is the responsible authority specified in all legislation and regulations governing insurance. The acronym DAPS will be used only when the context so requires.

148. The supervisory policy followed by the MoF has been the focus of broad consultation with the private sector, in the course of meetings with the Moroccan Federation of Insurance and Reinsurance Companies (FMSAR) and the Advisory Committee on Private Insurance (CCAR). The CCAR has 10 specialized commissions and its meetings are recorded in minutes that are disseminated widely among insurance company managers.

Moreover, legislation provides that sanctions may be imposed and licenses revoked only with the advice of the CCAR. However, assessments of the financial situation of an individual company may not be disclosed, for reasons of confidentiality (given the impact on the company's portfolio and commercial position).

149. This evaluation was prepared by Mr. Luc Carcinal, Senior Financial Sector Specialist with the World Bank, and Ms. Annabelle Assémat of the International Finance Corporation.

\section{Overview of the institutional and macroprudential environment and market structure}

150. The Moroccan insurance and reinsurance industry consists of 18 companies, of which 14 are private corporations, three are mutual companies and one is state-owned. of these 18 companies, 10 are active in life insurance as well as non-life insurance, three are engaged only in non-life insurance, two engage only in assistance transactions (one in life insurance, the other in credit insurance), and the last is a reinsurance company.

151. The Central Reinsurance Corporation (SCR), the only Moroccan reinsurer active in international reinsurance markets, was created in 1960 and is owned 95 percent by the CDG, the Caisse de Dépot et de Gestion (CDG). The SCR is not supervised by the DAPS. The government provides it with an unlimited guarantee. Moreover, the assistant director of the DAPS is a member of the SCR's board of directors. It is legally entitled to ten percent of all the premiums written by Moroccan insurers. For the fiscal year ending December 31, 2000, insurance companies ceded about 20 percent of written premiums to reinsurers. In the same

${ }^{19}$ Decree No. 2-78-539 of November 22, 1978. 
year, reinsurers ceded about 14 percent of written premiums - representing DH1.4 billionto the SCR. This amount included optional and contractual reinsurance, in addition to the legal transfer of ten percent.

152. The SCR earned a profit in 2000 and 2001 , but it suffered operating losses in 1998 and 1999, which were absorbed by the realization of exceptional earnings from the transfer of securities and by booking capital gains on real property. The SCR was exposed to insurance claims in connection with September 11, for which it recorded losses of DH 54 million in 2001. Despite this, it managed to earn a profit.

153. The Moroccan insurance market has consolidated considerably over the last six years. In 1995, decrees issued by the MoF ordered the liquidation of five bankrupt companies, and in 2000 , there were two major mergers.

154. The insurance industry in Morocco is now highly concentrated: two major financial groups, held nearly 52 percent of the shares of insurance companies at the end of 2001.

155. There are three types of insurance intermediaries in Morocco: agents, brokers, and direct offices. The only difference between an agent and a broker in Morocco is that the agent represents the insurance company or companies to which he is under contract, while the broker represents the client. The new insurance cade will reduce to two the number of insurers that an agent may represent. The number of agents stood at 508 in 2001 . There were 184 brokers. Some brokers and agents got together in 1994 to form the National Federation of Insurance Agents and Brokers in Morocco (FNACAM), but it does not speak for all intermediaries.

\section{Prerequisites for Effective Insurance Supervision}

156. The standards governing accounting and auditing for private firms in Morocco are based primarily on the principles and procedures of France and the Eusopean Union (fourth directive on annual financial statements, 1978). Major modifications were introduced a few months ago. Among these are a new commercial accounting framework and measures for enhancing the professional status of auditors. Implementation of the new standards is at the preliminary stage.

157. The financial sector and the business sector as a whole underwent a period of liberalization and reform in Morocco during the 1990s, particularly with respect to legislation and regulations. The current regulatory framework for the insurance industry is based on two laws: (a) the Decree of September 6, 1941, on insurance, reinsurance and capitalization activities, which constitutes the general framework for government activity in the insurance sector; and (b) the decree of November 28, 1934, on insurance contracts. Other laws also affect activities in this sector, including the decree implementing the law of October 9, 1977, on the presentation of insurance transactions and on the status of insurance agents.

158. There is currently a legal loophole with respect to insurance activities by banks. This has allowed the banks to compete with insurance companies, with the tacit approval of 
the authorities. This situation is supposed to be regulated in the forthcoming insurance code, a draft of which is now before parliament.

159. Under that draft code, no single shareholder may hold more than 50 percent of the capital of an insurance company. The new rules, if adopted, would pose a serious problem that could undermine the development and health of the insurance industry, particularly in terms of competition and capitalization. The ceiling may be justified on the grounds that it prevents the company from being controlled by a single shareholder. However, this new restriction could have perverse effects, by giving rise to undeclared share transfers where the assignor retains ownership as a means of circumventing the legal limits. This situation could also conflict with the obligation of the reference shareholder to come to the rescue of the company with further capitalization in case of difficulties.

160. The new draft cade also requires the joint-and-several liability of insurers in cases of coinsurance. While such a rule might appear logical, it runs the risk of limiting the coinsurance market since, if one of the partners defaults, the other coinsurers' liability will exceed the originally contracted limits.

161. The insurance industry complains that the mechanisms introduced by the new code are unmanageable, particularly when it comes to coinsurance and the ceiling imposed on capital structure. The industry has also criticized the way the authorities have gone about finalizing the code and presenting it to parliament without consulting the industry properly.

162. The system of business governance in Morocco follows that of French civil law. The question of business governance in Morocco has been the focus of great debate, particularly in terms of providing adequate protection for minority shareholders in the administration of companies. There has been significant progress on the legislative front, in particular the preparation and review of essential legislation such as Law SA 17/95 which provides the framework for the governance of corporations and a growing awareness of the importance of sound business governance, as a means both of ensuring corporate responsibility and of encouraging the development of capital markets and investment. The next stage will be to bridge the gap between legislation and practice.

\section{B. Main Findings}

163. The evaluation of compliance with the IAIS core principles shows a high degree of non-observance. Weaknesses were situated mainly in the areas of internal governance, internal control, asset and risk management and information-sharing with foreign supervisory agencies. However, it should be noted that the principles address many issues that are new in the field of insurance supervision, and that many countries have implementation problems at the present time. 


\section{Recommendations}

\section{Table 2. Recommended Action Plan for Improving Observance of the IAIS Insurance Core Principles}

\begin{tabular}{|c|c|}
\hline Principle & Recommended action \\
\hline $\begin{array}{l}\text { Organization of an } \\
\text { insurance supervisor } \\
\text { Principle ] }\end{array}$ & $\begin{array}{l}\text { A study should be undertaken to determine the financial, political and operational } \\
\text { independence of the DAPS and to suggest a new system of operation. }\end{array}$ \\
\hline $\begin{array}{l}\text { Licensing and changes } \\
\text { in control } \\
\text { Principles 2-3 }\end{array}$ & $\begin{array}{l}\text { The MoF should insist that members of the board of directors and managers meet } \\
\text { minimum standards of knowledge and expertise in the insurance industry. }\end{array}$ \\
\hline $\begin{array}{l}\text { Corporate governance } \\
\text { and internal controls } \\
\text { Principles 4-5 }\end{array}$ & $\begin{array}{l}\text { An analysis of the business governance framework is underway. The conclusions } \\
\text { and recommendations as they relate to the insurance sector should be considered } \\
\text { promptly and used to reinforce governance in insurance companies. } \\
\text { Work is underway on the development of internal control standards. Morocco } \\
\text { could benefit from examining the measures adopted in other countries. }\end{array}$ \\
\hline $\begin{array}{l}\text { Prudential rules } \\
\text { Principles 6-10 }\end{array}$ & $\begin{array}{l}\text { There should be laws and regulations concerning asset management } \\
\text { arrangements, and weaknesses in the areas of risk management (market risk, } \\
\text { credit risk, liquidity risk, legal risk, operating risk etc.), investment management, } \\
\text { internal controls, accountability of the board of directors, and auditing procedures } \\
\text { need to be addressed. } \\
\text { The MoF should establish restrictions and disclosure rules for derivatives and } \\
\text { off-balance sheet items. } \\
\text { The MoF should obtain information from the supervisors of foreign insurance } \\
\text { companies. }\end{array}$ \\
\hline $\begin{array}{l}\text { Market conduct } \\
\text { Principle } 11\end{array}$ & $\begin{array}{l}\text { Rules should be adopted requiring insurers and intermediaries to behave honestly } \\
\text { and transparently, to conduct their activities with due skill, care and diligence, to } \\
\text { meet clients" needs for information, and to treat all clients equitably. } \\
\text { Insurers should also be required to take steps to avoid conflicts of interest, to deal } \\
\text { with policyholders' complaints, and to resolve disputes. }\end{array}$ \\
\hline $\begin{array}{l}\text { Monitoring, on-site } \\
\text { inspection and } \\
\text { sanctions } \\
\text { Principles } 12-14\end{array}$ & $\begin{array}{l}\text { The MoF should hire outside experts in certain areas: computer experts, for } \\
\text { example, could assess whether data protection procedures are adequate. } \\
\text { in moving gradually to a risk-based supervisory system, the existing "early } \\
\text { warning system" should be linked to the on-site inspection program. The MoF } \\
\text { should conduct more frequent and comprehensive inspections. The hiring of } \\
30 \text { new inspectors in coming months should help in this regard. } \\
\text { As the MoF's financial and human resources are finite, a new, more selective, } \\
\text { framework for risk-based on-site supervision would be advisable. } \\
\text { There should be a graduated schedule of penalties and corrective measures, } \\
\text { ending with revocation of licenses, which should be communicated to insurance } \\
\text { companies (the new code now awaiting approval contains such a schedule). }\end{array}$ \\
\hline $\begin{array}{l}\text { Cross-border business } \\
\text { transactions, }\end{array}$ & $\begin{array}{l}\text { Laws and regulations should allow the MoF to conclude agreements for the } \\
\text { exchange of information with other countries. }\end{array}$ \\
\hline
\end{tabular}


coordination and cooperation, and confidentiality

Principles 15-17

The draft amendments to the banking law call for coordination among supervisory bodies, and this could be reflected in legislation governing other financial activities, particularly insurance.

Laws and regulations should be amended to allow the exchange of information with other supervisory bodies. This is increasingly urgent, given the existing degree of concentration in Morocco, and the presence of sizable financial conglomerates involved in several sectors of the industry (insurance, banking, pension funds etc.).

\section{Authorities' Response}

164. The MoF provided feedback on the mission's evaluation, submitted additional information and suggested corrections. The authorities thought that they deserved a more positive assessment. The mission has taken the MoF's input into account in its final report, and has reconsidered all contested principles in light of the authorities' argumentation. The assessment on contested principles was modified in those cases where the evidence submitted by the authorities warranted it. The authorities stressed the fact that the assessment was based on the draft Insurance Code. Since then, the code has been updated and the last version accommodates several concerns expressed by the mission, particularly in paragraphs 159 , 160 and 161.

\section{SuMMary ASSESSMENT OF OBSERVANCE OF THE IOSCO ObJeCtives AND Princtilles for SECURITIES Regulation}

\section{A. General}

165. The assessment of the effectiveness of securities market supervision was conducted in Rabat and Casablanca in February 2002, as part of the FSAP missions for Morocco. The assessment reflects the situation as of February 2002 and does not take into account any legal or tegulatory changes since that date.

166. This evaluation of observance of the Objectives and Principles for Securities Regulation of the International Organization of Securities Commissions (IOSCO) is based on interviews and discussions with representatives of the Securities Ethics Council [Conseil Déontologique des Valeurs Mobilières, CDVM], the Casablanca Stock Exchange, the Professional Association of Brokerage Companies, market intermediaries, mutual fund managers (OPCVMs), and other market participants.

167. The assessment is also based on a review of legislation, decrees and circulars, whether currently in force or in preparation, as well as on documentation on the market and its operation. It was made by Andrés Jaime, financial specialist with the World Bank. 


\section{Regulatory framework}

168. Regulatory responsibility for the securities market lies primarily with the MoF and the CDVM. The CDVM was established by Decree-Law No. 1-93-212 of September 21, 1993 , with the objective of protecting investors in securities and proposing the necessary measures for this purpose.

169. The CDVM is responsible for ensuring that corporations accepting funds from the public provide information in a manner consistent with existing laws and regulations. The CDVM is also responsible for supervising securities markets and for helping the government in matters related to regulation of these markets.

170. The MoF is responsible for regulating the securities market, and must in particular approve the specifications [Cahier de Charges] of the Stock Exchange, the statutes of the Central Depository, and the general regulations [Règlement Général] of those two institutions. The $\mathrm{MoF}$ is also responsible for licensing securities market intermediaries. The CDVM is essentially responsible for supervising securities market intermediaries, such as the Stock Brokerage Companies and the Collective Investment Schemes (OPCVMs) and approving the information disclosed to the public by savings-taking corporations and by OPCVMs. The Bank Al-Maghrib is responsible for supervising credit institutions, which represent the vast majority of securities-custody institutions and which play the role of depository for the assets of the OPCVMs.

171. The two central entities of the market, the Casablanca Stock Exchange and the Central Depository (Maroclear) fall under the direct control of the MoF. The CDVM is not responsible for their supervision.

\section{Market structure}

172. The Casablanca Stock Exchange, one of the oldest securities markets in Africa, was created in 1929. Since then it has undergone several structural reforms. The last one, which dates to 1993, was part of a broader reform of the securities market that established the current regulatory and technical frameworks. The Casablanca Stock Exchange has the second-highest capitalization, after that of Egypt, of any in North Africa and the Middle East.

173. The 1993 reform was based on three laws that govern the activities of the regulatory body (CDVM), of the Casablanca Stock Exchange and of the mutual funds. In 1997, a fourth law regulated the Central Depository for the securities markets (Maroclear). Trading activity is managed and supervised by the Casablanca Stock Exchange Corporation [Societé de la bourse de valeurs de Casablanca, SBVC], a limited liability company owned entirely by the brokerage firms active on the exchange, which acts as a cooperative body and has been granted an indefinite management concession.

174. Apart from shares, a limited number of public and private bonds are quoted on the Casablanca Stock Exchange, but their total market value and the volume of bonds traded are relatively low. 
175. Brokerage companies, licensed by the MoF, have a monopoly on transactions at the Casablanca Stock Exchange. There are 13 such firms. In addition to trading transactions, they are engaged in securities safekeeping, the placement of corporate issues, portfolio management and advisory services.

176. Following a reorganization of the stock exchange in 1993, stock prices and trading volumes rose steadily until the end of 1998, when the turnaround in investment flows sparked a downward trend that has not yet been reversed. The rising prices and trading volumes in the mid-1990s were encouraged by reforms that simultaneously strengthened the demand for equities and their supply. On the demand side, the creation of mutual funds helped to channel a portion of household savings into the stock market, while on the supply side the privatization policy, which was based on public offerings and private placements, led to the issuance of new equity shares. Structural reforms were strengthened by the concomitant upsurge in foreign portfolio investment in emerging markets, which was reversed by the Asian crisis of 1997.

177. At the end of 2001, the Casablanca Stock Exchange listed 53 companies (compared to 54 in 1999), with a total capitalization of DH104.7 billion (compared to DH138.1 billion in 1999). Transaction volume fell even more significantly, from DH94.3 billion in 1999 to DH26.7 billion in 2001. The market is highly concentrated, as the five largest companies account for 47 percent of the market's capitalization, and the five most heavily traded shares represent 54 percent of trading volume.

\section{B. Main Findings}

178. The review of compliance with the IOSCO objectives and principles reveals that while significant progress has been made in the recent past in the regulatory and institutional aspects of supervision of securities markets, the underlying legal framework remains somewhat inadequate and needs substantive improvement. The regulator has upgraded its inspection and surveillance capabilities. However, it lacks certain key inspection and enforcement powers, partially compromising the ultimate impact of its efforts to fully supervise the market. At the same time, in the last few years the regulator has issued a large number of well-crafted technical regulations, which notwithstanding their possible lack of legal basis in case of judicial challenge, constitute a solid set of regulatory norms for the market.

179. Although the law establishes broad mandates for supervision of the multiple entities involved in the securities market, the lack of legislative harmonization has led to significant fragmentation of responsibilities. Moreover, two key market participants, the Stock Exchange and the Central Depository, are not subject to the regulator's control.

180. From a statutory viewpoint, the CDVM is not an independent agency. In particular, the Minister of Finance serves ex officio as chair of its board of directors; the director-general is appointed, and can be removed, by Dahir (royal decree); and the majority of the members 
of the board of directors of the CDVM are appointed by the government, and their mandate can be revoked at any time.

181. The CDVM has only limited powers for fulfilling its mandate. Most of the powers of licensing, supervision, and sanctions lie elsewhere, and the supervisory powers of other authorities over the two key market institutions (the Securities Exchange and the Central Depository) are not sufficient. Moreover, the power to set technical standards for the market, which the CDVM does in practice through its circulars, has no clear legal basis, and could be challenged before the courts. However, the CDVM's financial and human resources appear generally appropriate for its tasks.

182. The inspection, investigation, and surveillance powers of the CDVM are not adequate. In particular, CDVM lacks the power to supervise and inspect the key market institutions. CDVM's powers to share information and coordinate actions with other regulators are adequate with respect to foreign authorities, but there is a substantial void with respect to the domestic supervisory and inspection authorities. This is of concern since most securities market participants are part of financial conglomerates.

183. There has been substantial progress in accounting and audit standards for corporations in Morocco in recent years, but more remains to be done to bring them in line with international standards. In particular, consolidation of financial statements is not currently required.

\section{Recommended Actions}

Table 3. Recommended Action Plan for Improving Observance of the IOSCO Objectives and Principles for Securities Regulation

\begin{tabular}{|c|c|}
\hline $\mathrm{Pr}$ & Recommended actions \\
\hline W & $\begin{array}{l}\text { The supervisory powers of the regulator should be expanded to cover the } \\
\text { Securities Exchange and the central depository, particularly with respect to } \\
\text { their systems and procedures and their observance of norms and operational } \\
\text { rules. } \\
\text { Members of the CDVM's board of directors, as well as its director-general, } \\
\text { should be appointed for fixed terms, and there should be clear and } \\
\text { transparent rules for their removal from office. A formal mechanism should } \\
\text { also be established for the CDVM to report to a higher authority, providing } \\
\text { fuller details on its activity than what is contained in its arnual report. } \\
\text { The CDVM should have adequate powers, inchuding for licensing market } \\
\text { intermediaries, supervising the market's central institutions and defining } \\
\text { detailed norms for the application of regulations through circulars, which } \\
\text { should be made legally binding by the Executive branch. }\end{array}$ \\
\hline & \\
\hline $\begin{array}{l}\text { Self-regulatory organizations } \\
\text { (SROs) (Principles 6-7) }\end{array}$ & $\begin{array}{l}\text { A thorough analysis of the } \\
\text { self-regulatory bodies (Seo } \\
\text { professional associations) }\end{array}$ \\
\hline
\end{tabular}




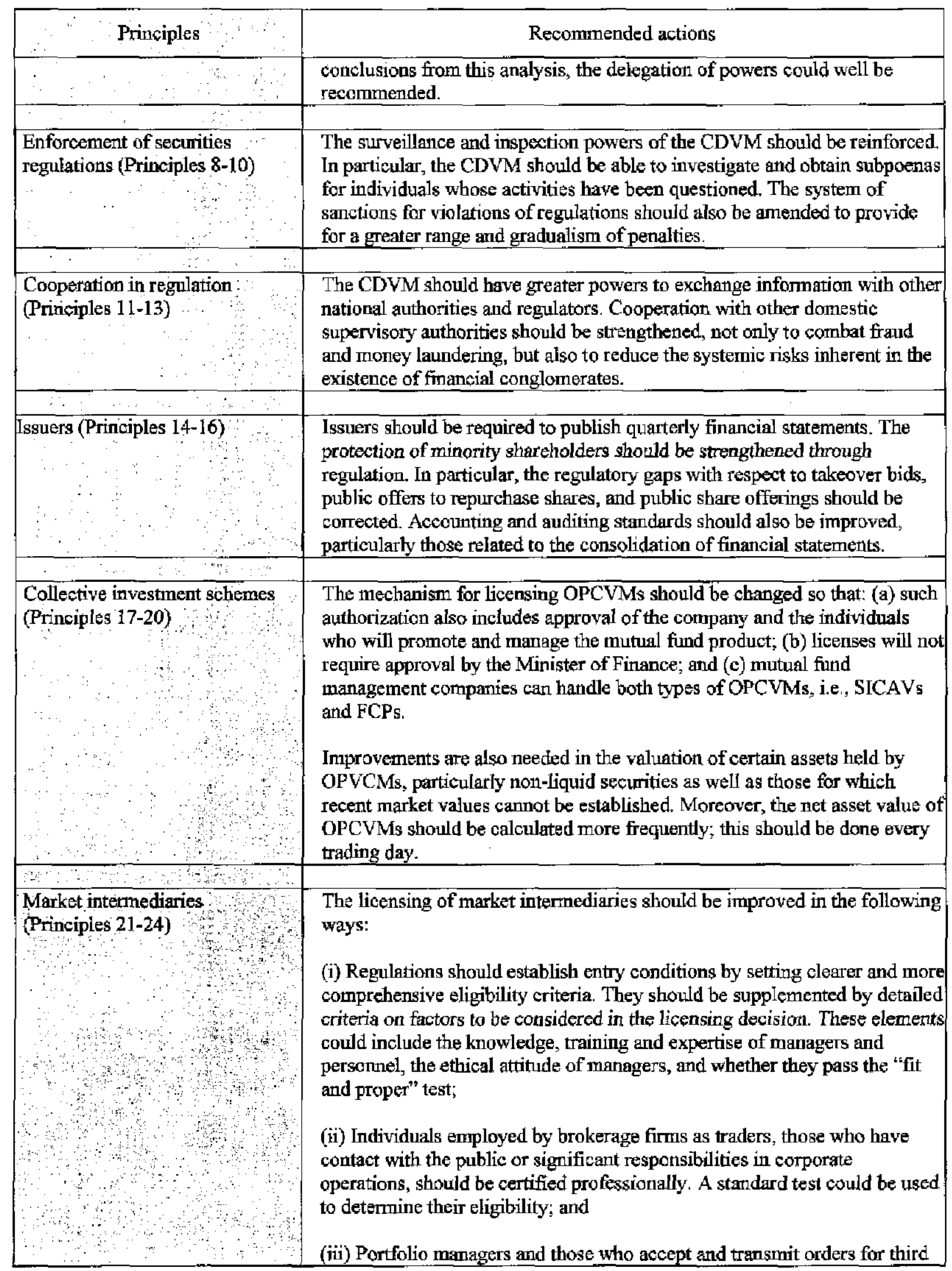




\begin{tabular}{|c|c|}
\hline ples & Recommended actions \\
\hline & $\begin{array}{l}\text { parties should also be licensed. } \\
\text { The guarantee fund for default of intermediaries should be managed not by } \\
\text { the CDVM, but by the Securities Exchange or the profession itself. }\end{array}$ \\
\hline$\therefore$ & \\
\hline $\begin{array}{l}\text { Market intermediaries } \\
\text { (Principles 25-30) }\end{array}$ & $\begin{array}{l}\text { The CDVM should have the power to supervise the Securities Exchange's } \\
\text { compliance with legal and regulatory provisions, particularly those } \\
\text { contained in its General Regulations. It should also be able to ensure that } \\
\text { proper ethical standards are adopted and complied with by the Securities } \\
\text { Exchange. } \\
\text { The CDVM should also have the power to ensure that securities market } \\
\text { transactions are conducted in accordance with rules of transparency and } \\
\text { ethics. It should therefore be able to verify that the systems and technical } \\
\text { means used by the Securities Exchange for the secondary market are } \\
\text { consistent with standards of security and faimess. } \\
\text { As to clearing, delivery and settlement systems, with the introduction of a } \\
\text { system for simultaneous delivery and payment of securities and a system to } \\
\text { guarantee completion of transactions, the securities market should be } \\
\text { virtually in conformity with the IOSCO principles. The key factor still } \\
\text { outstanding is the CDVM"s lack of supervisory power over institutions } \\
\text { responsible for clearing and settlement. } \\
\text { In particular, the CDVM should be able to verify the central depository's } \\
\text { compliance with legal and regulatory provisions, particularly those } \\
\text { contained in its General Regulations. The CDVM should also be able to } \\
\text { ensure that proper ethical standards are adopted and complied with by the } \\
\text { central cepository. }\end{array}$ \\
\hline
\end{tabular}

\section{Authorities' Response}

184. The authorities welcomed most of the conclusions of the evaluation. In their comments, they pointed out some factual errors and areas where differences in interpretation were possible. These refer in particular to: (i) the procedure for appointing and removing the general director of CDVM; (ii) the authority for determining funancial policy for the securities market; (iii) the auditing of CDVM financial statements as of the last fiscal year; (iv) the incorporation of detailed financial statements into the annual report of CDVM; (v) the frequency of brokerage firms' reporting to the CDVM; and (vi) the requirement for quarterly publication of financial indicators for issuers. 


\section{Summary Assessment of ObServance of the CPSS CORE PRINCIPLes for SYSTEMICALly IMPORTANT PAYMENT SYSTEMS}

\section{A. General}

185. This assessment of Moroccan practices with respect to payment systems was prepared by Mr. Charlie Garrigues, Senior Payment Systems Specialist at the World Bank, as part of the FSAP for Morocco. The evaluation is based primarily on a questionnaire completed by the BAM and on an examination of legislation, regulations, and procedural documents cited in the detailed analysis. This evaluation is an integral part of the FSAP, and reflects the situation as of May 2002. It does not take into account any legal or regulatory changes that may have happened since then.

186. The assessment was conducted in close cooperation with relevant officers of the Bank Al-Maghrib (BAM) and the MoF and through interviews with managers of the major commercial banks, the general director of the GPBM (Professional Association of Moroccan Banks), the general director of the Interbank Electronic Payments Center (CMI), and the general director of Maroclear.

187. In methodological terms, the evaluation is based on the "Guidance Note for Assessing Observance of Core Principles for Systematically Important Payment Systerns," published jointly by the World Bank and the IMF in August 2001.

\section{Context}

188. The Moroccan payment system can be characterized by the following elements: (i) cash payments occupy a pre-eminent position, because of the low rate of banking penetration; (ii) paper instruments (checks and notes) are dominant; (iii) the number of payment cards in circulation is significant, but the lack of compatibility between the four processing centers severely limits the use of payment cards; (iv) checks, money orders and notes are exchanged in 20 clearing houses and require each bank at each presentation site to have sufficient cash on hand to cover clearance balances; (v) settlement times are satisfactory for on-site clearance, but are not in line with the needs of a modern economy for off-site clearance; (vi) with respect to large-value transactions (currency and financial markets, clearing house balances, securities transactions), procedures for recording transactions are not integrated and much information must be transferred on paper, by fax or telex; and (vii) there are plans to establish an integrated network for real-time clearance, but the timing of this move has yet to be determined.

189. Because manual procedures are used, and because of the way the BAM is involved in the system, the situation described above does not pose any systemic risk in practice. However, it is unsatisfactory in terms of efficiency of clearance and settlement, and it is holding back development of the financial sector, particularly the retail banking sector. Furthermore, it does little to promote greater use of banking services among the public or to diminish reliance on cash transactions, which pose costs and risks for all economic agents. 
190. Two major projects are being undertaken to overhaul the infrastructure of Morocco's payment systems. These two projects are the Moroccan Interbank Tele-Clearance System (SIMT), which became operational in June 2002, and the Interbank Electronic Payments Center (CMI), which is scheduled to become operational during the first half of 2003 .

191. There is a need for better coordination among players and projects, however, on two major points: (i) defining policy and supervisory responsibilities for payment systems within the BAM; and (ii) coordination and consultation with all participants in establishing a plan to overhaul the infrastructure of the payment system over the medium term.

\section{The identification of a systemically important payment system}

192: In the context described above, there is, stricly speaking, no systemically important payment system to which the core principles can be applied. Given the state of progress of the SIMT, which is supposed to handle all media of payment and was expected to handle about 70 percent of the flows of funds within the country as of June 2002, it was agreed with the BAM to focus the assessment on the SIMT as it is to be implemented, while including the settlement procedures of the BAM associated with the SIMT.

\section{Legal and institutional framework: overview}

193. According to Article 37 of its statutes, the BAM "may take any initiative to facilitate the movement of funds, and to see to the creation and functioning of clearing houses." There is no explicit mention of overall surveillance of payment systems, and in practice the BAM performs only operational functions (functioning of the clearing houses and settlement system). Thus, there is no department or office in charge of designing and implementing policy and supervision or maintaining an overview of the payment system. Nevertheless, there has been coordination involving several directorates and departments of the BAM (Inspection, Internal Audit, Credit Institutions Supervision, Computerization, Legal) through its Directorate General, in the course of developing the SIMT project. There is a need for a multidisciplinary entity to oversee the responsibilities described in the core principles.

194. The Central Bank assumes the operational function of managing the 20 regional clearing houses. The Casablanca branch plays an essential role here: it clears 70 percent of transactions, and it is responsible for centralizing advances to cover debit balances of other clearing houses. It also handles interbank transfers to cover the banks' current accounts, settles clearing operations of the Casablanca clearing house and the SIMT, and securities transactions, etc. 


\section{B. Main findings}

Table 4. Main Findings of the Assessment of Observance of the Core Principles for Systemically Important Payment Systems.

\begin{tabular}{|c|c|}
\hline Principle & Main conclusions \\
\hline $\begin{array}{l}\text { Il. The system's rules and procedures should enable } \\
\text { participants to have a clear understanding of the } \\
\text { system's impact on each of the financial risks they } \\
\text { incur through participation in it. }\end{array}$ & $\begin{array}{l}\text { The BAM automatically provides advances at the } \\
\text { end of the day, although in principle it can order } \\
\text { the clearing operation to be adjusted manually by } \\
\text { extracting a few large transactions in the event of } \\
\text { settlement failure by a participgnt. Moreover, } \\
\text { experience in areas other than the payment system } \\
\text { has shown that some settlement failures have had to } \\
\text { be covered by other participants. This environment } \\
\text { must be greatly improved by introducing adequate } \\
\text { protection mechanisms (such as collateralization } \\
\text { funds) that limit the risks incurred by each } \\
\text { participant in the system, in particular by the BAM, } \\
\text { and by enabling large transactions to be processed } \\
\text { in a Real Time Gross Settlement System. }\end{array}$ \\
\hline $\begin{array}{l}\text { V. A system in which multilateral clearing takes } \\
\text { place should, at a mimimum, be capable of ensuring } \\
\text { the timely completion of daily settlement in the } \\
\text { event of an inability to settle by the participant with } \\
\text { the largest single settlement obligation. }\end{array}$ & $\begin{array}{l}\text { The system for settling multilateral balances at the } \\
\text { end of the day is subject to the risk of failure by a } \\
\text { participant, and the potential reversal of certain } \\
\text { transactions, unless the BAM advances funds to } \\
\text { cover that participant's debit balance at close of } \\
\text { business. This situation should be corrected, both } \\
\text { through a proper protection mechanism (see above) } \\
\text { and by excluding large-value transactions from the } \\
\text { net transaction system and handling them under a } \\
\text { gross settlement system. }\end{array}$ \\
\hline $\begin{array}{l}\text { VIII. The system should provide a means of making } \\
\text { payments, which is practical for its users and } \\
\text { efficient for the economy. }\end{array}$ & $\begin{array}{l}\text { The SIMT payment system, which is now being } \\
\text { tested in Casablanca, does not yet have a timetable } \\
\text { for eliminating paper exchanges and for covering } \\
\text { exchanges for the whole country. It cannot be } \\
\text { considered at this time, therefore, as effective and } \\
\text { practical for users, either the banks or their major } \\
\text { clients. The absence of a real-time large-value } \\
\text { settlement system is also a handicap for financial } \\
\text { markets and for large industrial and international- } \\
\text { trade transactors. }\end{array}$ \\
\hline
\end{tabular}

\section{Recommendations}

195. The BAM's statutes are vague about its role in the payment system. The current revision of these statures should include adding an article specifying the BAM's supervision role, to the effect that "the BAM ensures the proper functioning and security of payment systems, both those managed by the BAM and those managed by external public or private entities." 
196. It was mentioned several times that coordination among the players responsible for proper functioning of the payment system could be improved. It would be desirable therefore to create a National Payments Council (representing all players concerned) to determine reforms in this area, and to monitor and evaluate their implementation. This council should be charged with preparing a plan for the overall modernization of payments infrastructure and for identifying the composition and reporting relationship of the entities that will oversee the implementation of such a project.

197. The BAM does not have a unit responsible for payment system policy and supervision. Along with clarification in its statutes of its role and its policy and supervision duties, establishment of a multidisciplinary department in charge of these issues within the BAM would help to improve policy formulation, oversight of modernization projects, and supervision over the new systems (SIMT and CIM). These new provisions should be published on the BAM's website.

Table 5. Action Plan for Improving Observance of the Core Principles for Systemically Important Payment Systems

\begin{tabular}{|c|c|}
\hline Core principle & Recommended actions \\
\hline $\begin{array}{l}\text { I. The system should have a well-founded legal } \\
\text { basis under all relevant jurisdictions. } \\
\text { VIII The system should provide a means of } \\
\text { making payments, which is practical for its users } \\
\text { and efficient for the economy. }\end{array}$ & $\begin{array}{l}\text { Basic questions requiring technical and legal attention: } \\
\text { - Procedures and schedule for extending the system to } \\
\text { the whole country, with gradual abolition of the } \\
\text { clearing houses other than that of Casablanca. } \\
\text { Procedures and schedule for eliminating paper } \\
\text { exchanges and retaining evidence in case of } \\
\text { litigation. } \\
\text { Legalization of electronic proof ( signatures, files, } \\
\text { non-repudiation etc.). } \\
\text { Coverage and protection for the system against debit } \\
\text { balances of a size that cannot be covered at the end } \\
\text { of the day, so as to eliminate any risk of non- } \\
\text { settlement in case of liquidity crisis. } \\
\text { Design and implementation of a plan for reform and } \\
\text { comprehensive modernization of the infrastructure of } \\
\text { payment systems and instruments. }\end{array}$ \\
\hline $\begin{array}{l}\text { II. The system's rules and procedures should } \\
\text { enable participants to have a clear understanding } \\
\text { of the system's impact on each of the financial } \\
\text { risks they incur through participation in it. } \\
\text { V. A system in which multilateral netting takes } \\
\text { place should, at a minimum, be capable of } \\
\text { ensuring the timely completion of daily } \\
\text { settlement in the event of an inability to settle by } \\
\text { the participant with the largest single settlement } \\
\text { obligation. }\end{array}$ & $\begin{array}{l}\text { Banks' cash positions are not centralized and finaticial } \\
\text { institutions have no information on those positions even } \\
\text { at the end of the day; the BAM sets no limit on the Net } \\
\text { Buyer Position (PONA) of Maroclear for the large banks } \\
\text { in the delivery-against-payment procedure, a fact that } \\
\text { limits the scope for effective risk management by the } \\
\text { BAM and the treasurers of financial institutions. } \\
\text { The precarious condition of some banks requires } \\
\text { adequate protection mechanisms (collateralization fund } \\
\text { for example) that limit the risks to participants in the } \\
\text { system, especially to the BAM. }\end{array}$ \\
\hline
\end{tabular}


Responsibility A. The central bank should clearly define its payment system objectives and should disclose publicly its role and major policies with respect to systemically important payment systems.

Responsibility $\mathrm{D}$. The central bank, in promoting payment systern safety and efficiency through the core principles, should cocperate with other central banks and with any other relevant domestic or foreign authorities.
The new BAM statutes should specify its guidance, management and surveillance responsibilities for payment systems.

The creation of a payment systems unit within the BAM would facilitate the formulation of policies and objectives.

Moreover, there should be greater consultation and coordination between the BAM and financial institutions on the modernization of the payment systems as a whole. A National Payments Council should be established, in which the major players and beneficiaries of the system (BAM, banks, economic transactors, consumers ete.) would establish strategic guidelines and an overall reform plan including the projects now under way.

Political and technical monitoring of these projects should be conducted at the highest level and with maximum transparency.

\section{Authorities' Response}

198. The authorities discussed the assessment in great detail. Their comments have been incorporated into the final version of this assessment, and no significant differences of opinion remain.

199. Senior officials of the BAM have already given consideration to implementing certain recommendations: specifying the BAM's duties in the banking law, creating a specific unit within the BAM, creating a National Payments Council, undertaking consultations to devise a medium-term strategy for reform and modernization of Morocco's payment systems and instruments.

\section{Summary Assessment of Observance of the Code of Good Practices on Tramsparency in Monetary and Financial Policies}

\section{A. Code of Good Practices on Transparency in Monetary and Financial Policy- Monetary Policy}

\section{Preface}

200. This assessment of practices on transparency in monetary policy in Morocco was conducted by Messrs. Fernando Delgado and Laurent Bouscharain ${ }^{20}$ in the context of the February and May 2002 FSAP missions for Morocco. The assessment is based primarily on

${ }^{20}$ Economists with the Monetary and Exchange Affairs Department of the IMF. 
the statutes of the BAM (Decree No. 1.59.2.33 of 30/6/1959), the banking law (Decree No. 1.93.147 of 6/7/1993), BAM publications, information available on the BAM website including its bulletins, discussions with BAM executives, and responses to questionnaires submitted to the Moroccan authorities. The assessment reflects the situation as of May 2002. Any legal or regulatory changes since then may affect the continued validity of its findings and conclusions.

\section{Legal and institutional framework - overview}

201. Decree No. 1.59.2.33 of 30/6/1959 establishes and specifies the statutes of the central bank, and Decree No. 1.93 .147 of 6/7/1993 on the banking law establishes and specifies certain powers of the BAM.

\section{Main findings and recommendations}

Table 6. Main Findings of the Assessment of Observance of the Code of Good Practices on Transparency-Monetary Policy

\begin{tabular}{|c|c|}
\hline Subject & Main Findings \\
\hline $\begin{array}{l}\text { I. Clarity o } \\
\text { Central Bar } \\
\end{array}$ & $\begin{array}{l}\text { The law does not clearly specify whether it is the } \\
\text { govemment or the central bank that sets exchange } \\
\text { rate policy and, if responsibility is shared, what the } \\
\text { exact role of the central bank is. Also, the } \\
\text { legislation is not clear in assigning priority to } \\
\text { BAM's objective of maintaining domestic monetary } \\
\text { stability, over and above its other responsibilities. }\end{array}$ \\
\hline को। & $\begin{array}{l}\text { iot publish the min } \\
\text { board's meetings, } \\
\text { are not analyzed on } \\
\text { ublications on mon } \\
\text { he criteria for appo } \\
\text { vernor and board n }\end{array}$ \\
\hline -nol & $\begin{array}{l}\text { Despite efforts to disseminate information, the } \\
\text { public is not necessarily well informed about } \\
\text { monetary policy, because institutional } \\
\text { responsibjlities, objectives, procedures and even } \\
\text { certain operations are not explicitly formulated, but } \\
\text { are part of a poblic affairs management culture in } \\
\text { which a fairly transparent administrative structure } \\
\text { coexists with informal decision-making structures. }\end{array}$ \\
\hline $\begin{array}{l}\text { IV : Accountability and Assurances of Integrity by the } \\
\text { Central Bank. }\end{array}$ & $\begin{array}{l}\text { ounts are not audited, except by the } \\
\text { roller's office. Objectives and } \\
\text { M's monetary policy management } \\
\text { he King, but they are not presented } \\
\text { with the parliament. }\end{array}$ \\
\hline
\end{tabular}

202. Clarification of the BAM's ultimate objective would help prioritization and enhance accountability. The BAM is entrusted with several responsibilities under its current charter, 
and seems to give priority to supporting the government's policy objectives rather than to defending monetary stability. The necessary clarification would also have to specify whether monetary stability is understood to refer to domestic or external stability.

203. The law should be more precise in defining the authority in charge of exchange rate policy. The present legal framework gives neither the MoF nor the BAM an explicit mandate to set exchange rate policy. In practice, however, the exchange regime is decided by the minister of finance in consultation with the governor of the BAM, and he BAM is responsible for the day-to-day implementation of exchange rate policy.

204. A prohibition on direct BAM participation in the capital or management of financial institutions would eliminate potential conflicts of interest. The current statutes allow for such participation without specifying any purpose or criteria. The coming review of the BAM's statutes is expected to address this issue.

205. Systematic assessment of the results of monetary policy, compared with government objectives, would allow the public to judge the BAM's performance. The macroeconomic analysis found in the BAM's annual report could be tied more systematically in the BAM's monthly and quarterly reports, and be enhanced with analysis of the impact on the prospects for the central bank's pursuit of its policy objectives, as announced annually in the CNME's report. This would help the public to understand better the reasons and thought process behind monetary policy decisions and, implicitly, foreign exchange policy decisions.

206. Better defined and more transparent criteria for appointing and removing members of the BAM's board of directors would enhance its independence and credibility. The lack of transparency in the removal criteria may be seen as a source of influence over the BAM that could reduce its independence and its credibility with the public.

207. The BAM's role in the handling and resolution of banking crises should be clarified. Although its statutes do not expressly require it to act as lender of last resort (except for overnight advances collateralized by treasury bills), in the event of a systemic risk or shortfall in resources of the Deposit Guarantee Fund, it is unlikely that the BAM would fail to assist illiquid institutions. The division of responsibilities between the MoF and the BAM in this regard could also be clarified.

208. Transparency in the BAM's management could be enhanced by institutionalizing arrangements for public accountability. For example, the governor could present and explain the results of the BAM's policies before a public session of parliament; internal control standards and criteria could be made public; the rules governing managers and employees of the BAM in the conduct of their private financial affairs could be strengthened by including supervision mechanisms and sanctions in the BAM's personnel regulations; and the BAM could publish the nature of the legal defense that it would use in case of lawsuits against an employee in the exercise of his duties. 
209. The code of good practices on transparency recommends that central bank accounts be audited by an independent auditor, preferably one outside of the government. In Morocco, BAM accounts are audited only by the government controller.

Table 7. Recommended Actions to Improve the Transparency of Monetary Policy

\begin{tabular}{|c|c|}
\hline Subject & Main Findings \\
\hline $\begin{array}{l}\text { I. Clarity of Roles, Responsibilities, and Objectiv } \\
\text { Central Banks for Monetary Policy. }\end{array}$ & $\begin{array}{l}\text { Specify responsibilities for exchange rate policy. } \\
\text { Specify that the ultimate objective of monetary } \\
\text { policy is internal stability of the currency. } \\
\text { Specify or exclude BAM participation in the capital } \\
\text { or management of private financial institutions. }\end{array}$ \\
\hline $\begin{array}{l}\text { II. Open Process for Formulating and Ret } \\
\text { Monetary Policy Decisions. }\end{array}$ & $\begin{array}{l}\text { The BAM could consider publishing the minutes of } \\
\text { the Monetary Policy Board and, more generally, } \\
\text { adding more analysis and explanations to its regular } \\
\text { publications. } \\
\text { The criteria for removal of the governor and } \\
\text { members of the Monetary Policy Board should be } \\
\text { specified and made public. }\end{array}$ \\
\hline $\begin{array}{l}\text { III. Public Availability of Information on Monetary } \\
\text { Policy. }\end{array}$ & $\begin{array}{l}\text { Strengthen the analytic and explanatory content of } \\
\text { the BAM's monthly and quarterly publications. }\end{array}$ \\
\hline $\begin{array}{l}\text { IV. Accountability and Assurances of Integrity by the } \\
\text { Central Bank. }\end{array}$ & $\begin{array}{l}\text { The central bank's accounts should be audited } \\
\text { systematically, preferably by an authority } \\
\text { independent of the government. } \\
\text { The governor of the BAM should present the } \\
\text { objectives and results of monetary policy } \\
\text { management to partiament. }\end{array}$ \\
\hline
\end{tabular}

\section{Authorities' response}

210. The authorities were asked to comment on this evaluation, and several of their suggestions have been incorporated.

211. The authorities consider that the present definition of the objective of monetary policy in the statutes of the BAM and the mechanism for discussing the annual objectives of the BAM within the CNME constitute a sufficient guarantee for monetary stability.

212. The authorities stressed the progress that has already been made in disengaging the BAM from the private financial sector and noted that the amendments now being made to its statutes make specific provision for such divestiture. 
213. Finally, the authorities expressed reservations about the recommendation to present the results of monetary policy to parliament. They fear that such a provision could have harmful consequences for the BAM's independence.

\section{B. Code of Good Practices on Transparency in Monetary and Financial Policy- Financial Policies}

\section{Preface}

214. This assessment of observance of the Code of Good Practices on Transparency in Monetary and Financial Policies with respect to financial policies in Morocco was carried out as part of the FSAP mission that took place in May 2002. The assessment summarizes detailed assessments that covered the following agencies and responsibilities: the BAM, in its capacity as agency responsible for banking supervision; the MoF/DAPS, in its capacity as agency responsible for insurance oversight; the CDVM, as agency responsible for securities regulation; and the BAM, in its capacity as agency responsible for payment systems oversight.

215. This assessment is based primarily on the statutes of the BAM, the banking law, BAM publications, information available on the BAM Web site including its bulletins, discussions with BAM executives, and responses to questionnaires submitted to the Moroccan authorities. The assessment reflects the situation as of May 2002, and does not take into account any legal or regulatory changes that may have happened since that date.

\section{Legal and institutional framework-overview}

216. The Credit Institutions Supervisory Directorate (DCEC) is the administrative unit of the BAM responsible for supervising the banks in Morocco. Regarding insurance and financial markets, independent agencies (DAPS and CDVM respectively) have been given supervisory responsibilities. Regarding payment systems, BAM performs only operational functions. Namely, according to Article 37 of its statutes, the BAM "may take any initiative to facilitate the movement of funds, and to see to the creation and functioning of clearing houses." 


\section{Main findings}

Table 8. Summary of Main Findings of Assessment of Observance of Transparency Code Principles - Financial policies

\begin{tabular}{|c|c|}
\hline & \\
\hline $\begin{array}{l}\text { V. Clarity of Roles, Resp } \\
\text { Financial Agencies Resp }\end{array}$ & $\begin{array}{l}\text { Financial supervision could be undermined by } \\
\text { fragmented responsibilities between the supervisory } \\
\text { body and the policy authority (MoF) or external } \\
\text { institutions. Regarding payment systems, BAM is } \\
\text { given a broadly defined mandate and has therefore } \\
\text { no permanent internal structure to establish } \\
\text { guidelines or monitor performance and results in } \\
\text { this area. }\end{array}$ \\
\hline & $\begin{array}{l}\text { Reporting of financial policies appear to be } \\
\text { generally satisfactory since all relevant legislation is } \\
\text { published in Morocco's Official Journal } \\
\text { (Bulletm Officiel). However the process for policy } \\
\text { formulation is largely limited to the BAM and MoF } \\
\text { with only limited consultation of parties interested } \\
\text { in changes in the regulation. }\end{array}$ \\
\hline and & $\begin{array}{l}\text { Information on bank and financial market } \\
\text { supervision is readily accessible. The main } \\
\text { weakness regarding availability of infornation } \\
\text { pertains to the insurance sector, for which the } \\
\text { annual report of the Insurance and Social Welfare } \\
\text { Directorate (DAPS) is generally published late. This } \\
\text { delay not only hinders a proper evaluation of firms } \\
\text { in the sector, but also limits the public's ability to } \\
\text { evaluate of the prudential and supervisory } \\
\text { arrangements for the sector. }\end{array}$ \\
\hline 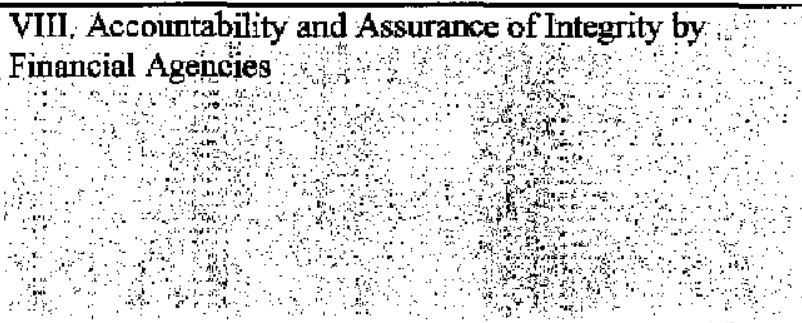 & $\begin{array}{l}\text { Regarding bank supervision and payment systems, } \\
\text { the BAM submits an annual report to the King, } \\
\text { which is made public afterward. Regarding financial } \\
\text { market and insurance supervision, the supervision } \\
\text { agencies report to the MoF. Those reports present } \\
\text { fairly aggregated financial statements of the } \\
\text { financial agencies, which limits their financial } \\
\text { transparency. }\end{array}$ \\
\hline
\end{tabular}




\section{Recommendations}

Table 9. Recommended Plan of Action for Improving Transparency of Financial Policies

\begin{tabular}{|c|c|}
\hline & Recommended action \\
\hline nar & $\begin{array}{l}\text { Clarify the distribution of responsibilities between } \\
\text { the BAM and the minister of finance and clearly } \\
\text { define the superviscry duties that external auditors } \\
\text { are expected to perform in the area of banking } \\
\text { supervision. } \\
\text { Reform the legislation defining the CDVM's actions } \\
\text { to enhance their effectiveness by reducing the } \\
\text { fragmentation of responsibilities. } \\
\text { The MoF should publish the means by which it is } \\
\text { held accountable for its insurance supervisory } \\
\text { activities. } \\
\text { The statutes of the BAM should specify its } \\
\text { objectives as they relate to the payment system, and } \\
\text { should assign responsibility to a single structure. }\end{array}$ \\
\hline 3 & $\begin{array}{l}\text { Clarify the distribution of banking supervisory } \\
\text { responsibilities between the BAM and the minister } \\
\text { of finance and reinforce consultation and publicity. } \\
\text { Establish a formal and transparent consultation } \\
\text { process with interested parties when changes are } \\
\text { made to financial market regulations. } \\
\text { Enhance the annual report and publish it more } \\
\text { promptly, to provide the industry a better } \\
\text { understanding of the objectives of insurance } \\
\text { supervision and information relative to the structure } \\
\text { of fees charged to insurance companies for } \\
\text { supervision. } \\
\text { If established, the permanent authority in charge of } \\
\text { payment systems should announce its objectives and } \\
\text { explain its activities. }\end{array}$ \\
\hline lici & $\begin{array}{l}\text { The annual report of the BAM should provide } \\
\text { greater detail on the objectives and achievernents of } \\
\text { banking supervision policy. } \\
\text { The CDVM should publish information more } \\
\text { frequently. } \\
\text { The DAPS ought to publish a more detailed report } \\
\text { that better reflects its own accounts as well as the } \\
\text { situation of the insurance sector. } \\
\text { Payment systems-related legislation could be made } \\
\text { more accessible. }\end{array}$ \\
\hline
\end{tabular}


IV. Accountability and Assurance of Integrity by Financial Agencies
Public reporting on banking supervision policy could be strengthened.

The CDVM should publish financial statements in sufficient detail and have them audited by an authority independent of the government. The CDVM should be accountable for its management of financial market policy, for example to an open session of parliament.

The insurance supervisory body should be accountable for its prudential policy and its own financial management to bodies other than the $\mathrm{MoF}$.

\section{Authorities' response}

217. The authorities were asked to provide comments on this assessment. Those comments have been incorporated into the final version of the report. There are no remaining points of significant disagreement. 
Table 10. Structure of the Financial System, End-2001 1/

\begin{tabular}{|c|c|c|c|c|c|}
\hline & & $\begin{array}{l}\text { Number of } \\
\text { institutions }\end{array}$ & $\begin{array}{c}\text { Assets } \\
\text { (in billions of } \\
\text { dirhams) }\end{array}$ & $\begin{array}{c}\text { In percent of } \\
\text { total }\end{array}$ & $\begin{array}{c}\text { In percent of } \\
\text { GDP }\end{array}$ \\
\hline Banks & & 19 & 344.9 & 59.7 & 88.9 \\
\hline Private banks & & 11 & 203.8 & 35.3 & 52.6 \\
\hline Public banks & & 8 & 141.1 & 24.4 & 36.4 \\
\hline Specialized banks & & 5 & 63.5 & 11.0 & 16.4 \\
\hline $\mathrm{CDG}$ & & 1 & 35.0 & 6.1 & 9.0 \\
\hline Insurance & & 18 & 61.0 & 10.6 & 15.7 \\
\hline Mutual funds & 2/ & 157 & 45.5 & 7.9 & 11.7 \\
\hline Financial leasing companies & $3 /$ & 9 & 10.4 & 1.8 & 2.7 \\
\hline Pension funds & $4 /$ & 5 & 55.0 & 9.5 & 14.2 \\
\hline Post Office & & 1 & 8.1 & 1.4 & 2.1 \\
\hline Consumer credit & 3) & 28 & 17.5 & 3.0 & 4.5 \\
\hline Total & & 238 & 577.5 & 100.0 & 148.9 \\
\hline
\end{tabular}

Sources: Banque al-Maghrib and staff calculations.

$1 /$ In the case of the insurance sector, the data refer to end-2000.

2/ At end-2000, there were 30 mutual fund management companies managing 141 funds.

$3 /$ The number of institutions refers to the situation as of end-2000.

4/ The number of institutions refers to pension plan management institutions. 
Table 11. Morocco: Overview of Regulatory and Supervisory Responsibilities, 2001

\begin{tabular}{llll}
\hline Institution & Regulator & Supervisor \\
\hline Banks & BAM & BAM \\
Insurance companies & MoF & MoF & \\
SCR & Government & Government \\
CDG & MoF & MoF/- & $1 /$ \\
Pension system & MoF/- & 1/ & (MoF) \\
Post office & - & CDVM \\
Microcredit companies & MoF & & \\
Mutual funds (OPCVMs) & MoF & CDVM \\
& CDVM & \\
Brokerages & MoF & BAM \\
& CDVM & BAM \\
Leasing companies & MoF & MoF \\
Consumer finance companies & MoF & BAM \\
Casablanca stock exchange & MoF & CDVM \\
Treasury bill market & BAM & BAM \\
& CDVM & CDVM \\
Corporate bond / TCN market & BAM & (BAM) \\
& CDVM & MoF \\
Payment system & - & - \\
Maroclear & MoF & BAM & \\
Offshore banks & BAF & \\
\hline
\end{tabular}

Source: IMF and World Bank staff, on the basis of information provided by the autherities.

1/ Not all pension systems are regulated and supervised.

2/ The supervisory arrangements for the microcredit companies are not in place yet. 
Table 12. Shareholdership of Selected Components of the Moroccan Financial System September 2001

\begin{tabular}{lccccccc}
\hline & Banks & Private Bk & Public Bk & CDG & Insurance & OPCVM & Leasing \\
\hline Gov/BAM & 25.2 & 4.2 & 52.6 & 100.0 & 0.0 & 0.0 & 0.0 \\
Banks & $* * *$ & 4.0 & 12.1 & 0.0 & 7.8 & 58.9 & 62.8 \\
$\quad$ Private Bk & 2.5 & $* * *$ & 2.2 & 0.0 & 7.1 & 54.3 & 56.8 \\
Public Bk & 11.7 & 1.3 & $* * *$ & 0.0 & 0.7 & 4.6 & 6.0 \\
CDG & 8.8 & 1.2 & 18.7 & $* * *$ & 0.6 & 11.0 & 0.9 \\
Insurance & 8.8 & 16.9 & 0.9 & 0.0 & $* * *$ & 0.0 & 15.5 \\
OPCVM & 0.6 & 1.1 & 0.0 & 0.0 & 0.0 & $* * *$ & 0.0 \\
Leasing & 0.0 & 0.0 & 0.0 & 0.0 & 0.0 & 0.0 & $* * *$ \\
Domestic & & & & & & & \\
agents & 23.4 & 35.5 & 7.7 & 0.0 & 48.9 & 21.8 & 15.4 \\
Foreign & 20.9 & 30.7 & 8.1 & 0.0 & 8.5 & 8.3 & 5.5 \\
\hline
\end{tabular}

Source: Staff calculations on the basis of data provided by the Moroccan authorities.

Note: The table presents the shareholdership of selected (groups of) financial institutions, as listed in the column headings. The shareholding agents are listed in the row headings. All numbers are expressed in percent of the total outstanding shares of the share-issuing institutions.

Table 13. Credit Exposures Between Components of the Moroccan Financial System, September 2001

(In percent of assets)

\begin{tabular}{lccccccc}
\hline & Banks & $\begin{array}{c}\text { Private } \\
\text { Bk }\end{array}$ & Public Bk & CDG & Insurance & OPCVM & Leasing \\
\hline Gov/BAM & 7.6 & 9.7 & 0.9 & 0.1 & 0.0 & 0.0 & 0.0 \\
Banks & $* * *$ & 1.8 & 1.6 & 0.5 & 3.0 & 11.9 & 8.3 \\
$\quad$ Private Bk & 1.3 & $* * *$ & NA & 0.3 & 2.9 & 11.7 & 8.2 \\
Public Bk & 0.5 & NA & $* * *$ & 0.2 & 0.1 & 0.2 & 0.2 \\
CDG & 0.0 & 0.0 & 0.0 & $* * *$ & NA & NA & 0.0 \\
Insurance & 0.3 & 0.4 & 0.0 & 0.0 & $* * *$ & NA & 0.0 \\
OPCVM & 0.4 & 0.6 & 0.0 & 0.7 & 18.6 & $* * *$ & 1.2 \\
Leasing & 1.5 & 1.6 & 1.3 & 0.0 & NA & NA & $* * *$ \\
Treasury Bills & 19.7 & 25.4 & 1.7 & 58.0 & 67.0 & 58.2 & 5.0 \\
Foreign & 2.1 & 2.6 & 0.3 & 0.0 & NA & 0.0 & 0.0 \\
\hline
\end{tabular}

Source: Staff calculations on the basis of data provided by the Morocean authorities.

Note: The table presents the exposure of selected (groups of) financial institutions to other institutions. The exposed institutions are presented in the column headings, and the exposures in the row headings. All numbers are expressed as a percentage of the exposed institution's assets. 
Table 14. Indicators of Financial Soundness of the Banking System, 1997-2002

\begin{tabular}{|c|c|c|c|c|c|c|}
\hline (Figures in percent) & 1997 & 1998 & 1999 & 2000 & $\overline{2001}$ & $\begin{array}{c}2002 \\
\text { (Sept.) } \\
1 /\end{array}$ \\
\hline Statutory capital, as a proportion of risk-weighted assets 2 & 11,2 & 12.6 & 12.1 & 12.8 & 12.6 & 12.5 \\
\hline Commercial banks & 12.7 & 13,1 & 13.0 & 14.7 & 15.3 & 15.3 \\
\hline Specialized banks & 6.1 & 11.1 & 8.3 & 5.9 & 1.2 & 0.5 \\
\hline Tier 1 capital, as a proportion of tisk-weighted assets & 11.2 & 12.6 & 12.1 & 11.0 & 15.5 & 15.0 \\
\hline Equity capital (net value) as a proportion of assets $3 /$ & 10.0 & 10.3 & 10.0 & 9.8 & 8.7 & 8.6 \\
\hline Growth rate of credit outstanding & 5.9 & 14.3 & 9.2 & 11.0 & 3.6 & 2.7 \\
\hline NPLs, in percent of total gross loans & 11.8 & 14,6 & 15.3 & 17.5 & 16.8 & 18.0 \\
\hline Commercial banks & 8.5 & 8.9 & 9.1 & 9.1 & 10.7 & 11.3 \\
\hline Spectalized banks & 23.8 & 27.5 & 29.2 & 42.3 & 32.2 & 36.4 \\
\hline Net NPLs, as a proportion of equity capital & 37.6 & 44.9 & 49.3 & 70.5 & 55.5 & 59.8 \\
\hline Commercial banks & 12.9 & 119 & 12.8 & 15.0 & 19.9 & 20,8 \\
\hline Specialized banks & 152.4 & 186.0 & 244.7 & 366.0 & 188.9 & 280.4 \\
\hline Provisions, as a proportion of nonperforming loans $4 /$ & 57,5 & 52.6 & 51.8 & 45.7 & 53.0 & 53.8 \\
\hline Commercial banks & 74.2 & 75.4 & 74.7 & 73.4 & 70.8 & 70.3 \\
\hline Specialized banks & 43,0 & 36.5 & 36.7 & 29.8 & 38.2 & 39.6 \\
\hline Large exposures (as a proportion of capital) 5/ & N/A & 159.0 & 196.0 & 212,0 & 194.0 & 148.0 \\
\hline Connected lending (as a proportion of equity capital) & 30.9 & 23.1 & 22.2 & $\mathrm{~N} / \mathrm{A}$ & 23.0 & 28.5 \\
\hline $\begin{array}{l}\text { Foreign currency loans (as a proportion of total loans to } \\
\text { customers) }\end{array}$ & 1.1 & 0.9 & 1.0 & 1.0 & 1.1 & 1.1 \\
\hline $\begin{array}{l}\text { Off balance-sheet exposure (gross, as a proportion of equity } \\
\text { capital) }\end{array}$ & 263.6 & 231.1 & 209.7 & 224.3 & 290.9 & 240,0 \\
\hline Average return on assets (ROA) & 1,0 & 0.9 & 0.7 & 0.7 & 0.9 & 0.7 \\
\hline Commercial banks & 1.1 & 1.1 & 0.1 & 1.1 & 1.1 & 1.1 \\
\hline Specialized banks & 0.2 & -0.1 & -0.8 & -1.0 & -0.1 & -1.0 \\
\hline Average teturn on equity (ROE) & 11.0 & 9.5 & 8.2 & 8.1 & 10.2 & 7.8 \\
\hline Commercial banks & 13.4 & 12.4 & 12.5 & 13.0 & 12.7 & 11.8 \\
\hline Specialized banks & 2.8 & -1.8 & -14.8 & -14.8 & -0.9 & -10.0 \\
\hline Interest margin (as a percentage of gross revenues) & 77,2 & 75.0 & 73.4 & 80.0 & 77.8 & \\
\hline Expenditure excl. interest (as a proportion of gross earnings) & 47.3 & 46.8 & 47.4 & 49.1 & 46.2 & 45.9 \\
\hline Persomel expenditure (as a proportion of gross earnings) & 30.7 & 30.4 & 30.7 & 31.3 & 29.2 & 28.3 \\
\hline Average spread between loan and deposit rates & 6.27 & 5.54 & 5.32 & 5.10 & 4.81 & 4.81 \\
\hline $\begin{array}{l}\text { Liquid assets (as a proportion of total assets) } \\
\text { Central bank credit to banks (as a percentage of bank }\end{array}$ & 25.4 & 24.1 & 22.9 & 20.4 & 22.7 & 22.4 \\
\hline resources] & 0.5 & 1.2 & 0.4 & 2.2 & 0.0 & 0.2 \\
\hline Bank deposits (as a percentage of bank resources) & 67.0 & 67.2 & 68.2 & 72.1 & 72.5 & 74.7 \\
\hline Demand accounts & 29.7 & 30.5 & 31.0 & 33.1 & 35.8 & 37.5 \\
\hline Demand accounts of Moroceans living abroad & 7.7 & 8.0 & 8.1 & 8.2 & 9.5 & 9.8 \\
\hline $\begin{array}{l}\text { Financial borrowings from foreign financial institutions (as } \\
\text { a percentage of resources) }\end{array}$ & $N / A$ & $N / A$ & $\mathrm{~N} / \mathrm{A}$ & $N / A$ & 3.3 & 3.1 \\
\hline Bank deposits (as a percentage of bank credits) & 114.6 & 113.5 & 112.0 & 113.4 & 120.3 & 125.1 \\
\hline $\begin{array}{l}\text { Net open position in foreign exchange (as a proportion of } \\
\text { equity capital) }\end{array}$ & N/A & N/A & N/A & N/A & N/A & N/A \\
\hline Difference between maximam and minimum interbank rates & 3.5 & 3.8 & 6.0 & 4.6 & 6.6 & \\
\hline Money market rate (average) $6 /$ & 6.7 & 6,3 & 5.6 & 5.4 & 4.8 & \\
\hline Spread between long rates and short rates $6 / 7 /$ & $\mathrm{N} / \mathrm{A}$ & 2.1 & 1.8 & 1.3 & 1.7 & \\
\hline
\end{tabular}

Sources: Bank accounting statements, summary statements, Statistiques monétatres, Bulletin trimestriel, authorities. 
1/ Data on capital are as of June-2002. Profitability indicators are annualized figures for the January to June 2002 period.

2/ For 1997, 1998, and 1999, the levels of equity capital used to calculate the solvency ratio are based solely on Tier 1 figures. For 2000 and June 2001, equity capital consists of Tier 1 and Tier 2 capital, as stipulated in Circular No. 4/G/2001 of Jamuary 15, 2001, which revised the definition of equity capital and certain risk weightings in accordance with international standards. Calculated on the basis of the earlier Circular, the solvency ratio for 2000 is 11.1 percent.

$3 /$ The figures for 1997-2000 include the profits for the year in equity capital. The figure for 2001 excludes them. The figure for 2001 that is comparable to the earlier figures is 9.6 percent.

4/ The figure for 2001 is provisional, pending establishment of provisions for the year by one of the commercial banks.

5/ Defined as the sum of exposures exceeding five percent of a bank's capital.

6/ The figure for 2001 refers to the period January-September.

7/ The difference between the average anmual interest rates on 10-year treasury bills and those on treasury bills at 26 weeks or less. 
Table 15. Analysis of the Profitability of the Banking System, 2001

\begin{tabular}{lccc}
\hline & Banking system & $\begin{array}{c}\text { Commercial } \\
\text { banks }\end{array}$ & $\begin{array}{c}\text { Specialized } \\
\text { banks }\end{array}$ \\
\hline & \multicolumn{2}{c}{ (In percent of Net Banking Product) } \\
Interest margin & 84.2 & 83.6 & 89.3 \\
Of which: public debt & 28.1 & 30.1 & 12.2 \\
Margin on commissions & 10.0 & 10.4 & 7.0 \\
Earnings from market operations & 2.5 & 2.2 & 4.7 \\
Miscellaneous earnings & 3.3 & 3.8 & -1.0 \\
Net Banking Product $1 /$ & 100.0 & 100.0 & 100.0 \\
& & & -65.1 \\
Operating costs & -53.5 & -52.0 & -38.4 \\
Provisions & -22.6 & -20.6 & -4.0 \\
Taxes on profits & -8.5 & -9.0 & 4.1 \\
Miscellaneous charges & 4.0 & 3.9 & -3.4 \\
Net result 2/ & 19.4 & 22.3 & \\
\hline
\end{tabular}

Source: BAM and staff estimates.

1/ Net banking product: the sum of the interest margin and other banking income.

2/ Net result: the difference between the sum of all revenues and the sum of all costs. 
Table 16. Aggregate Balance Sheet for the Banking System at End December 2001

\begin{tabular}{|c|c|c|c|c|c|}
\hline \multicolumn{3}{|c|}{ Assets } & \multicolumn{3}{|c|}{ Liabilities } \\
\hline & $\begin{array}{l}\text { Millions } \\
\text { of dirhams }\end{array}$ & $\begin{array}{c}\text { Percent of } \\
\text { total }\end{array}$ & & $\begin{array}{l}\text { Millions } \\
\text { of dirhams }\end{array}$ & $\begin{array}{c}\text { Percent of } \\
\text { total }\end{array}$ \\
\hline Cash and similar & 3,242 & 0.9 & Central bank & 0 & 0.0 \\
\hline Central bank & 21,881 & 6.1 & & & \\
\hline & & & $\begin{array}{l}\text { Interbank debts and } \\
\text { similar }\end{array}$ & 19,295 & 5.4 \\
\hline $\begin{array}{l}\text { Interbank deposits and } \\
\text { similar }\end{array}$ & 30,531 & 8.5 & Customer deposits & 268,185 & 74.9 \\
\hline $\begin{array}{l}\text { Loans to customers } \\
\text { Of which: }\end{array}$ & 177,464 & 49.6 & Debt securities issued & 21,432 & 6.0 \\
\hline net NPLs & 17,663 & 4.9 & Other liabilities & 15,458 & 4.3 \\
\hline $\begin{array}{l}\text { Debt securities } \\
\text { Of which: }\end{array}$ & 101,116 & 28.2 & & & \\
\hline Treasury bills & 73,170 & 20.4 & & & \\
\hline Other assets & 23,760 & 6.6 & Equity capital & 32,914 & 9,2 \\
\hline Total assets & 357,994 & 100.0 & Total liabilities & 357,994 & 100.0 \\
\hline $\begin{array}{l}\text { Total off- balance } \\
\text { sheet items }\end{array}$ & 127,120 & 35.5 & & & \\
\hline
\end{tabular}


Table 17. Morocco: Selected Macroeconomic Indicators

(Quota = SDR 588.2 miltion)

\begin{tabular}{|c|c|c|c|c|c|c|c|}
\hline $\begin{array}{l}\text { Population: } 29.2 \text { million (2001 estimate) } \\
\text { Per capita GDP: US } \$ 1,160 \text { (2001 estimate) }\end{array}$ & & & & & & & \\
\hline & 1997 & 1998 & 1999 & 2000 & 2001 & 2002 & $\begin{array}{l}\text { Proi. } \\
2003\end{array}$ \\
\hline \multirow{2}{*}{\multicolumn{8}{|c|}{ (Percent change; unless otherwise indicated) }} \\
\hline & & & & & & & \\
\hline Nominal GDP (billions of US dollar) & 33.4 & 35.8 & 35.2 & 33.3 & 33.9 & 37.1 & 42.0 \\
\hline Nominal GDP (billions of Dirhams) & 318.3 & 344.0 & 345.6 & 354.1 & 382.9 & 409.4 & 440.5 \\
\hline Real GDP & -2.2 & 7.7 & -0.1 & 1.0 & 6.5 & 4.5 & 5.5 \\
\hline \multirow[t]{2}{*}{ CPI period average } & I. 0 & 2.7 & 0.7 & 1.9 & 0.6 & 2.8 & 2.0 \\
\hline & \multicolumn{7}{|c|}{ (Percent of GDP) } \\
\hline Central government finances $1 /$ & & & & & & & \\
\hline Revenue 2/ & 25.4 & 27.2 & 26.9 & 26.2 & 24.9 & 24.0 & 23.2 \\
\hline Expenditure & 28,4 & 29.8 & 31.4 & 32.4 & 31.1 & 29.1 & 28.0 \\
\hline Overall balance $3 /$ & -3.4 & -2.6 & -4.5 & -6.4 & -5.7 & -4.5 & -4.3 \\
\hline Overall balance (including privatization receipts) 3 / & -3.1 & -2.5 & -1.3 & -6.4 & 0.4 & $-4,3$ & -2.7 \\
\hline
\end{tabular}

Money and credit

Broad money

Domestic credit

Net credit to government

Credit to private sector

Interest rate (52-woek treasury bills, in percent)

Batance of payments

Exports, f.o.b.

Imports, f.o.b.

Nel services

Current account

Current account (in percent of GDP)

Overall balance (deficit -)

Reserves

Gross official reserves (end of period)

(In months of imports of goods and nonfactor services)

Debt

Extemal debt (including use of Fund credit) $4 /$

External debt (in percent of GDP) 4/

Domestic government debt (in percent of GDP)

Total government debt (in percent of GDP)

Use of Fund resources

Repurchases

Fund credit outstanding

Exchange rate

Exchange rate (dirham/US dollar; period average)

Real effective exchange rate (appreciation + )

Terms of trade (deterioration -)

(Changes in percent of broad money ar the beyinning of the period)

$\begin{array}{rrrrrrr}9.0 & 5.8 & 10.3 & 8.4 & 14.2 & 6.6 & 7.0 \\ 7.1 & 6.5 & 3.4 & 9.4 & 0.4 & 5.1 & 4.7 \\ 2.3 & -0.8 & -3.9 & 3.9 & -2.4 & 1.8 & 0.7 \\ 4.8 & 7.3 & 7.3 & 5.5 & 2.8 & 3.4 & 4.0 \\ 6.7 & 6.6 & 4.7 & 5.3 & 3.2 & 2.9 & \ldots\end{array}$

(In billions of US dollar: unless otherwise indicated)

$\begin{array}{rrrrrrr}7.0 & 7.1 & 7.5 & 7.4 & 7.1 & 7.7 & 8.5 \\ 8.9 & 9.5 & 10.0 & 10.7 & 10.2 & 10.7 & 11.8 \\ -0.4 & -0.2 & 0.1 & 0.3 & 1.1 & 0.4 & 0.2 \\ -0.1 & -0.1 & -0.2 & -0.5 & 1.6 & 1.1 & 0.8 \\ -0.3 & -0.4 & -0.5 & -1.4 & 4.8 & 2.9 & 1.8 \\ 0.6 & 0.2 & 1.6 & -0.4 & 3.8 & 0.6 & 0.8 \\ & & & & & & \\ 4.2 & 4.6 & 5.7 & 4.8 & 8.4 & 10.1 & 10.8 \\ 4.7 & \mathbf{4 . 8} & 5.7 & 4.6 & 8.3 & 9.4 & 9.0 \\ & & & & & & \\ 19.1 & 20.6 & 19.8 & 18.0 & 15.9 & 16.1 & 15.2 \\ 57.1 & 57.5 & 56.1 & 53.9 & 47.0 & 43.7 & 36.1 \\ 38.2 & 38.1 & 41.3 & 42.2 & 45.9 & 47.9 & 49.4 \\ 78.0 & 74.3 & 76.9 & 76.4 & 74.8 & 70.7 & 68.2\end{array}$

(In militions of SDR; unless otherwise indicated)

$\begin{array}{lllllll}2.3 & 0.0 & 0.0 & 0.0 & 0.0 & 0.0 & 0.0 \\ 0.0 & 0.0 & 0.0 & 0.0 & 0.0 & 0.0 & 0.0\end{array}$

(Percent change unless otherwise indicated)

Sources: Ministry of Finance; Bank A1-Maghrib; and Fund staff estimates and projections.

1/ From 1997 to 1999 , data refer to fiscal years starting on July 1 of that year. From 2000, data refer to calendar year.

$2 /$ Excluding privatization and GSM license receipts.

3/ Including the balance of special treasury accounts not included in revenue and expenditure.

4/ Public and publicly guaranteed debt. 
Table 18: Results of the Stress Tests for Credit Risk 1/

\begin{tabular}{lrrr}
\hline Scenario 2f & Post-shock CAR & $\begin{array}{r}\text { Number of institutions } \\
\text { below 8 percent } \\
\text { regulatory minimum } \\
\text { CAR }\end{array}$ & $\begin{array}{r}\text { Number of insolvent } \\
\text { institutions }\end{array}$ \\
\hline No shock & 12.6 & 4 & 3 \\
Credit shock 1 & 8.3 & 7 & 4 \\
Credit shock 2 & 6.9 & 9 & 4 \\
Sectoral shock 1 & 11.8 & 4 & 3 \\
Sectoral shock 2 & 9.7 & 5 & 3 \\
Sectoral shock 3 & 7.0 & 5 & 3 \\
Sectoral shock 4 & 8.7 & 5 & 3 \\
Sectoral shock 5 & 8.1 & 5 & 3 \\
Sectoral shock 6 & 6.5 & 7 & 3 \\
Sectoral shock 7 & 10.4 & 5 & 3 \\
Sectoral shock 8 & 10.6 & 5 & 3 \\
\end{tabular}

Source: staff calculations on the basis of BAM data for December 2001.

1/ The overall credit shock tests used data for all 19 banks operating in December 2001. The sectoral shocks use data for 14 of the 19 banks. Sectoral data for the 5 other banks were unavailable, either because the institutions concerned did not report them, ${ }_{\text {, }}$ or because they did not have a loan portfolio.

2/ Definition of the scenarios:

Credit shock 1: 15 percent of performing loans are classified -60 percent as substandard and 40 percent as doubtful - and 50 percent of nomperforming loans are reclassified into the next more risky category

Credit shock 2: 50 percent of nonperforming loans are reclassified and placed in the next more risky category and half all unprovisioned substandard and doubtful loans, together with 100 percent of unprovisioned compromised claims, are lost

Sectoral scenarios: 1 , crisis in the phosphates sector; 2 , crisis in tourism and associated sectors; 3 , crisis in manufacturing; 4 , crisis in export sectors; 5 , crisis in the construction industry and real estate; 6 , crisis in government finance; 7 , crisis in the farming, fisheries, and related sectors; 8 , collapse of remittances by Moroccans living abroad. 


\section{Statement by Mohammed Daïri, Alternate Executive Director for Morocco April 28, 2003}

Over the past five years, Morocco has made important strides in modernizing its political system, continuously liberalizing the economy and increasing its resilience to shocks, and laying the foundations for faster and more sustainable growth, reducing poverty, and improving the living conditions of the population. In the context of a delicate political transition and unfavorable domestic and international economic environment-including three successive years of severe drought, the increase in oil prices, and global economic slowdown - the authorities maintained prudent fiscal and monetary policies and stayed the course of structural reform. As a result, real GDP growth accelerated and its vulnerability to volatile agriculture production declined, inflation was brought down to industrial countries' levels, and the external position strengthened significantly with current account surpluses, improvement in debt indicators, and substantial reserve build-up. Attractiveness to foreign direct investment increased, as evidenced by the successful sale of a cellular phone license and privatization of the national telephone operator. My authorities thank staff for the constructive dialogue during the Article IV discussions. They have agreed to the publication of the staff report for the Article IV consultation.

\section{Background}

Successful democratic transition has been the overriding priority of the Moroccan authorities during 1998-2002. It was indeed crucial to maintain social cohesion to create the appropriate climate for an open and credible electoral process. Much of the authorities' attention was devoted to reforming the electoral code, strengthening human rights protection, and achieving national reconciliation following past abuses. They demonstrated strong commitment to improving governance, transparency, and accountability. The legislative and executive branches were involved in parallel investigations on high profile mismanagement cases and their conclusions were brought to the judiciary through a transparent process. Last August, and for the first time in Morocco's history, a democratically elected government reported to Parliament on implementation of its political and socio-economic program announced at its investiture, a major breakthrough in accountability.

The general elections held in September 2002 have been universally acknowledged as the fairest and most transparent in Morocco's history. The new government and its program have the support of a wide spectrum of political parties and the business sector, which augurs well for policy implementation. Confidence has strengthened and market perception has improved as evidenced by the narrowing in spreads in the secondary market and improvement in Morocco's outlook rating.

\section{Macroeconomic policies and developments during 2001 - 2002}

With lower-than-average agriculture performance and continued strengthening of nonagricultaral activity, real GDP growth reached 4.5 percent in 2002 following 6.5 percent in 2001, allowing for an increase in real GDP per capita of 4 percent per year on average 
during 2001-2002. Improved government capacity to respond to droughts has helped attenuate their impact on the economy. The share of agriculture, including fisheries, declined from 15.4 percent of GDP during 1993-1997 to 13.8 percent during 1998-2002. While remaining high, urban unemployment has declined from a peak of 22.4 percent in 1999 to 18 percent in 2002.

Maintaining macroeconomic stability is key for achieving an enabling environment for high, sustainable, and private-sector-led growth. During 2001-2002, fiscal position improved significantly despite a decline in trade taxes following implementation of the FTA with the EU. After its peak of 6.4 percent of GDP in 2000, fiscal deficit, excluding privatization, declined to 5.8 percent in 2001 -instead of increasing to 7.1 percent as projected in the 2001 Article IV staff report-and to 4.5 percent in 2002. The 6.1 percent of GDP privatization revenue received in 2001 was not used to increase expenditure, which declined as a share of GDP from 31.8 percent in 2000 to 31.1 percent in 2001 and 28.9 percent in 2002 . Out of the DH 23.4 billion received in 2001 , DH 8 billion was used to reimburse central bank's statutory advance to the Treasury (which is unremunerated and is not included in public debt) and DH 10.6 billion was transferred to Hassan II Fund and sterilized in a central bank account. In 2002, the current fiscal balance reached close to 2 percent of GDP and the primary deficit was virtually eliminated. Total government debt, as a percent of GDP, declined from 75.7 percent in 2000 to 74.8 percent in 2001 and 69.4 percent in 2002 .

The effectiveness of monetary policy in achieving price stability, in an environment of large foreign exchange inflows, has been strengthened. Improved coordination between Bank Al-Maghrib and the Treasury and timely and effective use of policy instruments made it possible to mitigate the effect of privatization revenue and of the large increase in workers' remittances on liquidity. Money market rates remained within the central bank's intervention rates, and money developments were broadly maintained within the target range.

The exchange rate peg has continued to serve the economy well and has helped maintain macroeconomic stability. The depreciation of the dirham in April 2001, together with very low inflation and favorable movements of the euro in respect to the US dollar helped reverse part of the previous real appreciation. The authorities also followed a moderate wage policy. In view of the high level of unemployment and to protect competitiveness, the minimum wage was increased only once, by 10 percent in 2000 since 1996 , and has declined in real terms. The decline in interest rates and efficiency gains stemming from structural reforms also contributed to improved profitability and higher employment creation.

The tight macroeconomic stance, large workers' remittances and FDI inflows, improved export performance including from greater diversification to new, high value-added sectors-and active debt management policy led to significant improvement in the external position, notwithstanding the decline in tourism and global economic slowdown. The current account position turned from a deficit of 1.4 percent of GDP in 2000 to a surplus of 4.8 percent in 2000 and 3.7 percent in 2002 . External debt to GDP ratio declined from 48 percent in 2000 to 35 percent in 2002 , and debt service ratio declined further to reach 16.6 percent in 2002 . Reserve coverage increased to the equivalent of 9 months of imports. 
As a consequence, the ratio of external public debt net of official reserves to GDP declined from 71.5 percent in 1990 to 10.2 percent in 2002.

\section{Recent progress with structural reforms}

The authorities do not agree with the assessment that only a limited part of the government's reform agenda was implemented or that structural reform stalled for most of 2002. Despite the heavy political agenda and in addition to financial reforms, which will be highlighted in the following section, key reforms were implemented that included:

- Dismantling of tariffs under the Association Agreement with the EU (AAEU), with the more sensitive phase of progressive elimination of tariffs protecting local production starting this year;

- Elimination of reference prices and the adoption of customs valuation in accordance with WTO rules, leading to an improvement in Morocco's rating in the Fund trade restrictiveness index from 8 to 5 ;

- Modernization of customs administration bringing its performance on par to that of the most advanced economies and eliminating one of the most serious impediments to trade;

- Liberalization of the Telecoms sector, with World Bank assistance, allowing its opening to private sector involvement, including the sale of a second cellular phone license and privatization of Maroc Telecoms;

- Liberalization of the edible oil sector with elimination of the high tariffs and of consumer subsidies;

- Elimination of the price control system and enactment of the competition law;

- Enactment of the law liberalizing road transportation, and eliminating the state monopoly;

- Enactment of the law liberalizing the petroleum and gas sectors;

- Liberalization of the tobacco sector, and reform of its taxation consistent with IMF technical assistance recommendation, in order to prepare its privatization, expected to be completed later this year,

- Creation of regional one-stop windows to streamline investment procedures;

- Creation of working groups to identify and address impediments to key sectors development within a contractual framework, with priority given to improving their efficiency and export performance, reducing their costs, and improving access to land; 
- Adoption of a charter for small- and medium-sized enterprises and of employment support mechanisms, with particular emphasis on training;

- Reform of rent legislation to improve landlord protection and increase attractiveness of the sector to domestic and foreign investors;

- Revision of the privatization law to extend the list of public enterprises subject to privatization;

- Transfer to public pension funds of unfunded retirement schemes of key public enterprises, including the railway company (ONCF) and the tobacco company (Regie des Tabacs), and mobilization of resources equivalent to 2 percent of GDP for meeting their liabilities, with government support. This transfer will improve these enterprises' finances and transparency and help prepare them for privatization;

- Restructuring of the airline and maritime transportation companies and of a number of other public enterprises, and liquidation of the coal and iron mines companies;

- Adoption of a new law reforming public procurement regulation to enhance transparency and competition;

- $\quad$ Reform of job intermediation system;

- Strengthening of the judiciary with creation of commercial courts and regional courts of accounts and acceleration of execution of court decisions;

- Creation of an Ombudsman position to mediate disputes involving government entities.

\section{Financial sector reform and the FSSA}

Significant progress has been made over the past two years in strengthening the financial sector, including through improved regulation and supervision. In addition to the ongoing restructuring of specialized financial institutions, recent reforms include the overhaul of the accounting system to bring it on par with international best practices, the imposition of internal audit, the upgrading of loan classification and provisioning rules, and the imposition of prudential regulations on a consolidated basis. The draft law reforming the central bank's charter to provide it with more operational independence has been revised to include key FSAP mission recommendations. The law will assign price stability as the primary objective of monetary policy, create an independent monetary policy committee, prohibit budget financing under normal circumstances, phase-out central bank's shareholding in any financial institution, submit its accounts to independent external auditors, clarify the roles of the Ministry of Finance and the central bank in exchange rate policy, and open the possibility for the Governor to report to Parliament. The reform of the banking law aims at strengthening Bank Al Maghrib's supervisory role, redefining the roles of the two consultative bodies, and enhancing coordination among financial sector supervisors. The two revised draft laws are to be considered soon by the Government. After transformation of its legal statute, the opening 
of the capital of the major public commercial bank (BCP) is proceeding according to schedule. Following sale of 21 percent of its capital to private regional banks last year, the floatation of 20 percent of the capital has been announced recently. The new Insurance Code has been approved. This Code increases protection of the ensured and improves the regulatory and prudential framework. As recommended by the FSAP mission, the 50 percent shareholding limit in any insurance company and the joint liability in case of co-insurance have been eliminated.

My authorities thank staffs of the Fund and the World Bank for the exhaustive work carried out under the joint FSAP. While they share many of the assessments of the FSSA and concur with the needed reforms, they consider that the report does not fully and accurately reflect the recent major reforms and those in progress. They also believe that some of the vulnerabilities highlighted in the FSSA are either overstated or based on unrealistic assumptions inconsistent with the recent stance and orientation of macroeconomic policy and financial sector reform. They are of the view that vilnerabilities should be assessed against the present stance of policy and not in relation to what would happen if the capital account was liberalized. Capital movements are already free of restrictions for non-residents, including Moroccan workers abroad. The authorities are also aware of the prerequisites for moving toward full capital account liberalization and exiting from the present exchange rate peg and, in particular, the need for further improvement in the fiscal position, monetary framework and instruments, and strengthening of the financial sector. In this respect, they bave requested Fund technical assistance in bank and insurance supervision and pension reform. I will comment on a few areas of "vulnerability" identified by the mission.

\section{The specialized banks}

Two major factors explain the poor performance of the three specialized banks: the high cost of their long-term borrowing at historically high interest rates at a time when domestic interest rates have declined significantly, and difficulties faced by their borrowers, in particular in the drought-stricken agriculture and in tourism. These difficulties were exacerbated by poor governance which is being addressed forcefully. The restructuring and financial rehabilitation of the three institutions is being conducted in a transparent manner with reliance on the shareholders and direct or indirect government support. Despite the accumulation of reserves in the Deposit Guarantee Fund financed by contributions by the banking sector which could have been used for rehabilitation of the three institutions, these reserves were not used.

The Agricultural Bank (CNCA) received government support amounting to $\mathrm{DH} 1.2$ billion during 1998-2000 (0.4 percent of GDP) and was recapitalized by the Government in 2001 for an amount of DH 1.2 billion. A draft law modernizing its charter to enable private participation and separating the commercial part of its activity from social development objectives is under discussion in Parliament. Under the new law, all non-commercial activities will be undertaken on a contractual basis and will be financed by the Budget. Following severe shortcomings identified by an audit, management of the CNCA bas been changed and an improvement in its performance is underway with a significant increase in its deposit base and profitability. 
A restructuring plan covering 2000-2006 has been negotiated by the new management of the Housing and Tourism Bank (CIH). This plan calls on shareholders as well as government support for a total of DH 6.6 billion (over 1.5 percent of GDP), together with a program of loan recovery and cost reduction, including early repayment of expensive debt. Implementation of the plan is proceeding satisfactorily, with most of the financial support already disbursed. Two years into implementation, the plan has achieved a 30 percent decline in nonperforming loans, 20 percent increase in deposits, a significant increase in net banking product, and a decline in operational costs. While recognizing that the situation of the $\mathrm{CIH}$ is still difficult, the authorities and the $\mathrm{CIH}$ management are confident that the plan is working and that the bank will be put on a sound footing even earlier than anticipated under the program. Following its financial rehabilitation, the $\mathrm{CIH}$ could be privatized, or merged with another institution.

In addition to its deteriorating financial position, the role of the industrial development bank (BNDE) within the liberalized financial system was put into question. After considering several options, the authorities decided to liquidate the bank and transfer its retail bank activities to the Agricultural Bank (CNCA), which needs to develop its urban branch network, and its investment bank activities to the Caisse de Depots et de Gestions (CDG) which is a public asset management bank and also the second largest shareholder after the Treasury. A contract has been signed between the Government and the CDG giving this institution responsibility for the liquidation, with the final cost being borne by the CDG prorata to its shareholding and by the Government for the remainder.

While remaining committed to completing the rehabilitation and restructuring of the three specialized banks, the authorities do not believe that their situation had at any time posed serious risks to the stability of the financial system. The links between these institutions and the private financial sector are not very strong. Public disclosure of these institutions' weaknesses also provided assurance that the necessary restructuring and recapitalization measures would be taken by the authorities. Finally, the cost of recapitalizing the two insolvent institutions, to comply with the minimum capital adequacy ratios, was estimated by the FSAP mission at 1 percent of GDP.

The authorities do not see systemic risks to credibility of bank supervision arising from the exemption from prudential regulations granted to the two specialized banks. These exemptions are transparent and temporary and are accompanied by restructuring plans which are at an advanced stage of implementation. Furthermore, these exemptions do not create unfair competition to private banks in view of their significantly larger interest margins as well as the relatively small size and the sectoral concentration of the specialized banks.

\section{Risks related to the macroeconomic stance and public debt}

The authorities have demonstrated commitment to macroeconomic stability, and their stance of policies does not pose risks to the financial system. Indeed, the significant decline in government external debt and the increase in foreign reserves have mitigated most of the risks stemming from exchange rate and interest rate shocks. While part of the decline in external debt was replaced by domestic debt, this was achieved in a context of a general 
decline in domestic interest rates and has been instrumental in developing the financial system. Moreover, overall public debt has declined significantly, and this trend, under current policies, is expected to continue. The share of domestic debt in banks' assets is also relatively small, not exceeding 20 percent, and a significant part of it is held by a public bank. While there were episodes of accumulation of domestic arrears-the most recent being at end-2000 and was due to the delay in receiving the proceeds from the sale of the cellular phone license - there has never been any incidence of accumulation of domestic debt arrears. With strengthened fiscal position and expenditure control, enhanced cooperation with the central bank, and improved liquidity and debt management, the authorities are confident that there is no risk of accumulation of debt or non-debt arrears.

\section{Workers' remittances}

Workers' remittances have increased significantly over the past two years. Past episodes of rapid increases were typically followed by stability of the inflows with no incidence of sharp declines. Deposits held by expatriate Moroccans are maintained for liquidity purposes to face family support needs or for potential investments. Also these deposits are held in dirham, often in unremunerated accounts, whereas expatriate Moroccans have the opportunity of maintaining them in foreign currency, or in convertible dirham accounts. The authorities, therefore, do not see any risk of a sudden decline in these deposits.

\section{Interest rate formation}

The authorities do not agree that participation of public entities (CDG, BCP) in the Treasury bill market creates potential conflict of interest. The two institutions have full operational independence and make their investment decisions consistent with their own strategies. Interest rates are dictated by market conditions on an auction basis, and there is no evidence of collusion between the Treasury and these public entities. In the authorities' view, interest rate structure in the Treasury bill market appropriately reflects the preferences and anticipations of market participants and provide a credible benchmark.

\section{Social sectors and poverty reduction}

With assistance from the World Bank, the EU, and other donors, the authorities are implementing a broad strategy to increase delivery of social services and reduce poverty. This led to improvement in key indicators, including in education, health, access to drinking water and electricity, and significant progress in reducing geographic and gender disparities. Primary school enrollment increased from 65 percent in 1998 to 81 percent in 2001 on average. The gender gap is being closed with the rates of girls to boys increasing over the period from 0.94 percent to 0.99 percent in urban areas and from 0.73 percent to 0.80 percent in rural areas. Between 1997 and 2001, access to drinkable water in rural areas increased from 26 percent to 48 percent and access to electricity from 24.5 percent to 51 percent. An important breakthrough was the adoption of the Education Charter comprising several laws and regulations establishing a tight timetable for achieving universal enrollment, improving the quality of education, and strengthening its link to job market needs. An ambitious privatesector-led program for reducing housing shortages, particularly for the low-income 
population, is underway. Key social reforms also include the creation of the Social

Development Agency with World Bank assistance to address poverty issues, rehabilitation of key social protection agencies, including the Social Security Fund, and generalization of job accident and healthcare protection. The authorities also succeeded in developing a decentralized and efficient system for alleviating the social and economic effects of droughts, thereby strengthening the economy's resilience to weather-related shocks. This system has enabled a timely reallocation of budgetary resources while maintaining fiscal discipline and accountability.

\section{Data ROSC}

My authorities express their appreciation to the staff of STA for the comprehensive review of data dissemination and quality and concur with their conclusions and recommendations. The authorities have agreed to the publication of the report which has been already posted on the Fund's web site. This review has helped identify areas where more efforts are needed to enable Morocco to meet the SDDS requirements and to subscribe to the SDDS by end-2003.

\section{Policies for 2003 and the medium term}

The government's economic program announced last November aims at further modemizing the economy and enhancing its competitiveness to achieve higher and more balanced growth and job creation. In pursuit of this objective, the Government will rely on macroeconomic stability, structural reforms, human resource development, and strengthened governance and policy predictability to improve the attractiveness of the economy to domestic and foreign investors. Recent strengthening of business confidence and favorable weather developments so far augur well for acceleration of growth to 5.5 percent in 2003 , the average for the past two years. With improved outcome for 2002 , the traditionally conservative revenue projections, and strong revenue administration and expenditure control, the fiscal deficit could be closer to 4 percent than to the 5 percent projected during the Article IV discussions. Medium-term fiscal consolidation will remain at the core of the authorities' priorities, with the overall deficit, excluding privatization, projected to decline further to reach 3 percent of GDP by 2008 . In reaching this target, priority will be given to civil service reform, including a substantial retrenchment program based on early retirement and changing promotion into a merit-based system, liberalizing the sugar and cereal sectors and overhauling the untargeted subsidy system, and refoming the tax system to increase its buoyancy and offset the decline in trade taxes. The social orientation of the budget will also be strengthened to enhance the delivery of key public services.

Closer consultation with social partners augurs well for achieving early consensus on some of the pending issues, including the adoption of a new Labor Code. Broad consultation with the business sector will also belp introduce the necessary reforms for raising efficiency and competitiveness to enable the economy to reap the benefits of globalization and of the AAEU and the free trade agreements with Arab countries. Prospects for improved cooperation among Maghreb countries and of early conclusion of ongoing negotiations for a Free Trade Agreement with the U.S. are also encouraging. 
The effect of the war in Iraq has not been as severe as expected. Indeed, oil prices seem to have stabilized and the tourism sector, so far, has been affected less than in other countries in the region. Fiscal and price developments for the first two months have been favorable. Tourism receipts and workers remittances, in particular, have increased, while the trade deficit has widened, with an increase in exports more than offset by a surge in imports, especially for investment goods. However, foreign reserves were maintained at their historically high level of end-2002. While it is too early to assess the extent of the fall-out from the war, the authorities believe that the traditional political stability in Morocco and the safe environment, together with the large reserves cushion, will help maintain investor confidence and strengthen their resolve in the pursuit of their economic and social objectives.

My authorities attach high importance to their close cooperation with the Fund. The extensive exchange with staff during the Article IV, the FSAP, and data ROSC missions has been very useful. The authorities look forward to Board's discussion and advice in articulating and implementing their strategy. 